The University of San Francisco

USF Scholarship: a digital repository @ Gleeson Library | Geschke Center

2014

\title{
Artist as Citizen: Transnational Cultural Work in the National Democratic Movement of the Philippines
}

Ryan Anthony Leano

University of San Francisco, knowledge312@gmail.com

Follow this and additional works at: https://repository.usfca.edu/diss

Part of the Asian American Studies Commons

\section{Recommended Citation}

Leano, Ryan Anthony, "Artist as Citizen: Transnational Cultural Work in the National Democratic Movement of the Philippines"

(2014). Doctoral Dissertations. 102.

https://repository.usfca.edu/diss/102

This Dissertation is brought to you for free and open access by the Theses, Dissertations, Capstones and Projects at USF Scholarship: a digital repository@Gleeson Library | Geschke Center. It has been accepted for inclusion in Doctoral Dissertations by an authorized administrator of USF Scholarship: a digital repository @ Gleeson Library | Geschke Center. For more information, please contact repository@usfca.edu. 
The University of San Francisco

ARTIST AS CITIZEN: TRANSNATIONAL CULTURAL WORK IN THE NATIONAL DEMOCRATIC MOVEMENT OF THE PHILIPPINES

\author{
A Dissertation Presented \\ to \\ The Faculty of the School of Education \\ International and Multicultural Education Department
}

In Partial Fulfillment

of the Requirements for the Degree

Doctor of Education

\author{
by \\ Ryan A. Leano \\ San Francisco, California \\ May 2014
}




\section{THE UNIVERSITY OF SAN FRANCISCO \\ Dissertation Abstract}

Artist as Citizen: Transnational Cultural Work in the National Democratic Movement of the Philippines

The inspiration for this topic comes from my own experiences as a Filipino transnational cultural worker in this movement. There has been research done on Filipinos in the arts and social movements, however there is a paucity of information concerning Filipino cultural work. Cultural work and cultural workers are intentional in creating culture as an act of resistance to imperialism, as of the stories they tell though their creative work are not revealed much in mainstream media. Cultural workers also seek to debunk the myth of artists working in isolation from the community. As shared by the participants in this study, cultural workers are more importantly organizers working closely with marginalized communities, and in many ways are "popular educators" and "organic intellectuals."

The purpose of this study is twofold: to examine the extent to which cultural work brings political consciousness to marginalized populations in the Philippines and the U.S. who do not have access to education, and to examine the impact of cultural work locally and transnationally as a tool for social change and addressing issues that impact marginalized populations, particularly in the National Democratic Movement of the Philippines.

The qualitative methodology used for this study is narrative research, gathering the stories of Filipino cultural workers both in the Philippines and the U.S. These cultural workers are part of the National Democratic Movement of the Philippines. Data was collected in the Philippines and the U.S. through interviews and field observations. 
The participants in this study confirmed the assumptions offered by the theories that guided this work, through the experiences they shared. Their organizing through cultural work is in essence the social practice of Theater of the Oppressed. Their role as critical organic catalyst is exemplified their practice of being Artist-Teacher-OrganizerResearcher (ATOR) with the communities they align themselves with. Lastly, the cultural workers closely identified with the National Democratic Movement of the Philippines as a social movement with a distinct social process of transnational collective action. 
This dissertation, written under the direction of the candidate's dissertation committee and approved by the members of the committee, has been presented to and accepted by the Faculty of the School of Education in partial fulfillment of the requirements for the degree of Doctor of Education. The content and research methodologies presented in this work represent the work of the candidate alone.

Ryan A. Leano

Candidate

Dissertation Committee

Dr. Shabnam Koirala-Azad

Chairperson

Dr. Emma Fuentes

Dr. Robyn M. Rodriguez
August 15, 2014

Date

August 15, 2014

August 15, 2014

August 15, 2014 


\section{TABLE OF CONTENTS}

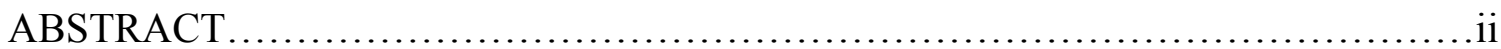

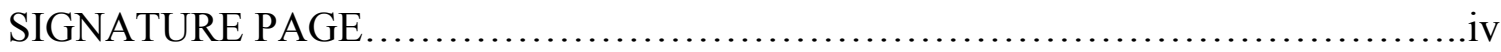

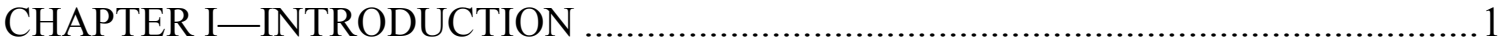

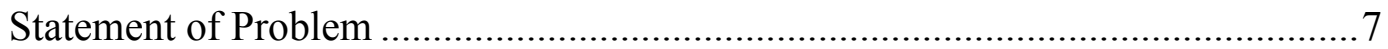

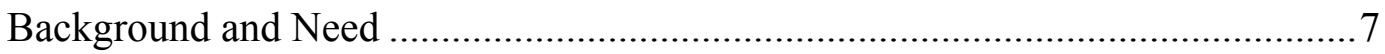

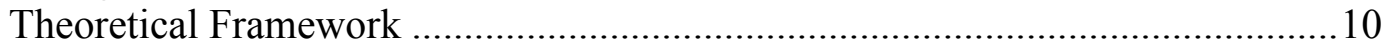

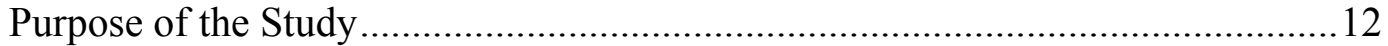

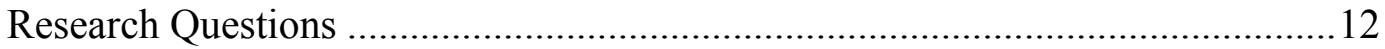

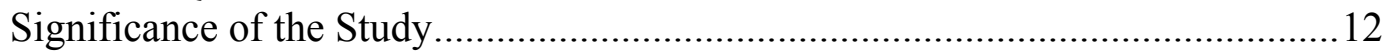

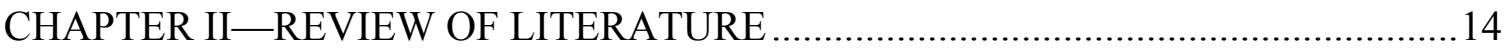

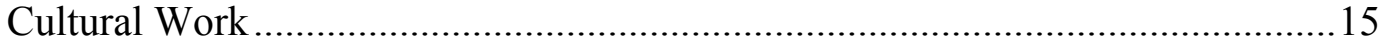

Theater of the Oppressed ................................................................. 15

Cultural Work/Worker Defined..............................................................17

Filipino Cultural Work ...................................................................20

Human Rights in the Philippines in a Historical Context....................................30

Miseducation and Decolonization in the Philippines .............................30

The Current Human Rights Crisis in the Philippines .............................40

Exploring the National Democratic Movement of the Philippines through Social

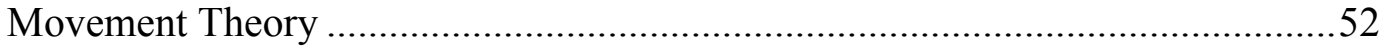

Social Movement Theory .....................................................................52

History of the National Democratic Movement of the Philippines ..........61

History of Filipino Migration and Transnationalism.........................................65

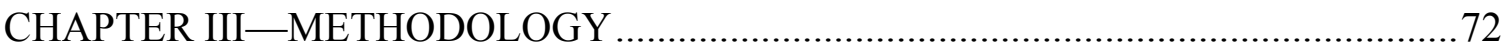

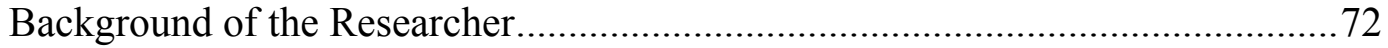

Restatement of the Purpose of the Study............................................................ 75

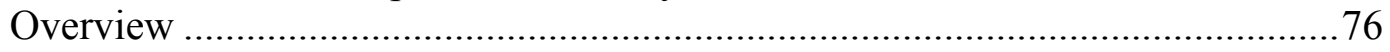

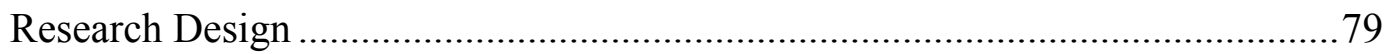

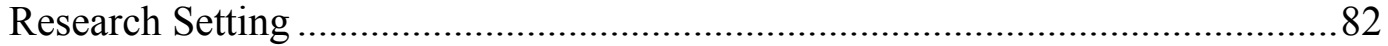

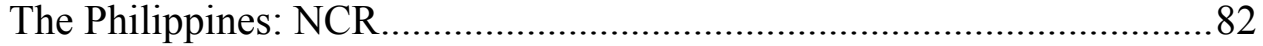

The United States: San Francisco Bay Area............................................8 83

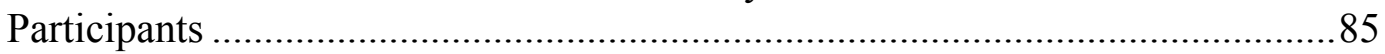

Cultural Workers in the Philippines ....................................................86

Cultural Workers in the United States.................................................... 88

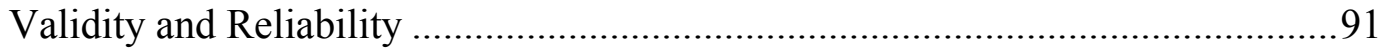

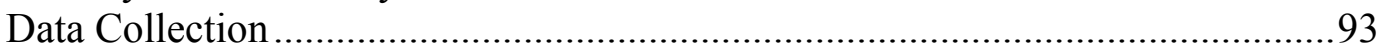

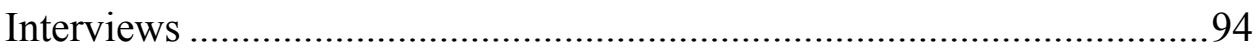

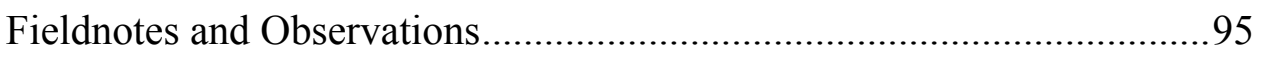

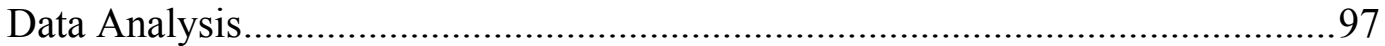

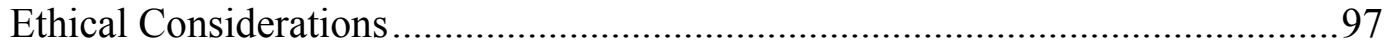


CHAPTER IV—FINDINGS

Research Question 1: According to cultural workers, what is cultural work and how does it look in a transnational context?

Defining Cultural Work and Cultural Workers .......................................100

The Role of Cultural Work Transnationally............................................107

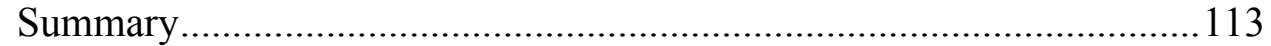

Research Question 2: How is cultural work used in the National Democratic Movement of the Philippines?...

Personal Experiences as Cultural Workers in the National Democratic

Movement

Highlights of Cultural Work in the National Democratic Movement.....131

Challenges of Cultural Work in the National Democratic Movement ....138

Summary

Research Question 3: What are the implications of cultural work for marginalized communities in the Philippines and the United States?

Cultural Work as Popular Education Towards Political Consciousness .146

Cultural Work as an Organizing Tactic for Social Change.

\section{CHAPTER V-DISCUSSION, CONCLUSIONS, RECOMMENDATIONS, AND}

REFLECTIONS

Discussion

According to cultural workers, what is cultural work and how does it look in a transnational context?

How is cultural work used in the National Democratic Movement of the Philippines?

What are the implications of cultural work for marginalized communities?

Conclusions

Recommendations for Further Research

Reflections of the Researcher 


\section{CHAPTER I}

\section{INTRODUCTION}

I was the first one to arrive. The space was like a second home to me, so I knew where everything was and how everything worked. I flipped the switches to illuminate the small but spacious hall. The warm and soft lighting were what I always liked about this space. I just felt the energy here was always welcoming, safe, and creative. Ironically, that's not the vibe I get outside, where this space is located, in the heart of the roughest slums in the South of Market Area of San Francisco. As I begin setting up the tables and chairs, I feel nervous about seeing her again. How would it be this time? The last time I saw her was when she was back from the Philippines, bravely smiling but I could still tell she was emotionally traumatized. She would lightly rub the still fresh bruises on her wrists and on the temple of her head. She could not walk straight. She could not talk without her eyes welling up. What I remember most from our last meeting was giving her a warm hug, knowing she was about to do something very dangerous yet courageous the next day. She was going back to the Philippines to testify against the military who abducted and tortured her.

I get my mind back to now, eight months later. My fellow organizers finally start to trickle in, setting up the posters around the room and large canvas on the wall. Despite the day-to-day grind of community work, locally and internationally, we are always happy to see each other. More people start showing up, some long-time friends, some who would meet her for the first time. When she finally arrives, I hardly recognized her. She was robust. She walked with a purpose and smiled at everyone with ease, something I haven't seen her do in a long time. "Hi Ryan!” she very warmly says to me. I 
immediately hug her the same way I did the last time I saw her, and say "It's so good to see you again, Melissa!' As everyone settles in and takes their seats, she begins to tell her story. "I am Melissa Roxas."

The mood in the room was quiet, but with a sense of safety and comfort. As Melissa tells her story, she paints a not very detailed yet a vivid picture of what the soldiers did to her during her five-day ordeal. I shudder to think of what was done to the thousands of Filipinos who were harassed, abducted, tortured, and disappeared by the Philippine military, simply for being critical of the government and advocating for human rights. Melissa was one of the lucky ones to have survived, others are still missing or have been executed. As she talks, she still rubs the scars on her wrists and temple and fights back the tears. "Talking about it is like going back to that dark, scary place. But I must tell my story because I refuse to remain silent." Melissa's story is just one of countless victims of human rights violations in the Philippines. "If I don't continue my work as an activist and cultural worker, it would be abusing my privilege as a U.S. citizen and a disservice to my people."

In December 2009, just months before Melissa shares her story with us, 57 journalists were viciously murdered in Maguindanao, Philippines. This incident is known as the Ampatuan Massacre. The victims were all part of an entourage on the way to file a certificate of candidacy of Ismael Mangudatu in the upcoming elections. Witnesses and evidence point to the private paramilitary of Andal Ampatuan, Jr., Mangudatu's rival candidate and known local warlord, as the perpetrators of the massacre. Although Ampatuan has turned himself in to the federal authorities, not one person has been tried or convicted, and justice for the victims seemingly out of reach. It's important to note that 
Ampatuan is a known ally of President Gloria Macapagal Arroyo and was instrumental in helping her win the election in 2004 through fraud, vote buying, and violent intimidation (Pagaduan-Araullo, 2009).

Also, just a few weeks before Melissa shares her story with us, 43 health workers were illegally arrested and detained in Morong, Philippines. They were at a health training seminar when the military forced themselves in and arrested all the health workers without warrants. The health workers, now known as the Morong 43, are accused of being communist rebels and were at a "bomb-making seminar," which witnesses testify as ridiculous and unfounded. They are still being detained to this day, with accounts of torture taking place. Melissa shared how she feels connected to the victims of these incidents. "Seeing and reading the news of these incidents really hit home for me, because I am a writer, and I was in the Philippines as a health worker, and I was abducted and tortured. I was accused of the same things the Morong 43 are accused of." Activists see these heightened violence against progressives and innocent people as the President Arroyo's desperate home stretch effort to "crush the insurgency by 2010," when her term as president ends. It is not coincidental that violence and impunity is heightened during this time, being an election year for president, seats in the Senate, and Congress. This violent operation by the Arroyo administration is known as Oplan Bantay Laya (Operation Protect Freedom) (Karapatan, 2010). Progressives and pro-people nationalist party-lists have been gaining much support from the broader public, which is a threat to the current administration.

I could tell the mood in the room became heavy. Some shed tears as they listened to Melissa's words. Melissa was asked by one of the listeners, "I really commend your 
bravery in continuing the struggle despite all the repression happening to our people. As an artist, what is the role of cultural work in the movement?" Melissa slowly made a big smile with a few tears in her eyes. "Cultural work is the heart of the movement. And it is also a source of healing in this protracted struggle." She then shared a poem she etched in her memory during the days of her torture, hoping she could share it if and when she would get out of her detainment:

$$
\begin{aligned}
& \text { Come before the Night Hour } \\
& \text { Come and Sing } \\
& \text { before Night } \\
& \text { Comes. I am Flame } \\
& \text { to the Body. } \\
& \text { The Incipient Wing } \\
& \text { that can't Fly. } \\
& \text { The Open } \\
& \text { Skin on a Foot } \\
& \text { that Bleeds } \\
& \text { Black. Tonight } \\
& \text { I will learn to Die } \\
& \text { a Thousand Times } \\
& \text { and Be Resurrected. }
\end{aligned}
$$

This was a great transition to what would happen next. Melissa introduced "Art Without Barriers," a project she is currently working on with Habi Arts, an artists collective under BAYAN-USA, an international chapter of BAYAN-Philippines, which is an anti-imperialist alliance of progressive Filipino and Filipino American organizations as part of the National Democratic Movement of the Philippines. "Art Without Barriers" is a live art petition for the release of the Morong 43 and to Stop Human Rights Violations. The finished product would then be sent to the Morong 43 in the Philippines. Folks headed over to the large canvas and broke out the paint, paintbrushes, markers, and spray paint. The only prompt was to give a message to the Morong 43 and to the Philippine government. 
What I was about to witness and participate in was truly organic. The mood in the room changed from somber to a room filled with smiles and laughter. At first, everyone was nervous about being the first one to paint on the canvas, until my 5-year-old niece takes her paint and starts it off. She paints a girl smiling and holding a flower. Her mom cheerfully asked, "Baby, what's that you're painting?” My niece answered, “That's Auntie Melissa!" Everyone else soon joined in the painting. Some never painted before, some were seasoned artists. Many images started to take shape around my niece's painting of Melissa — doves, hands breaking free of shackles, a clenched fist rising from the ground like a tree, hearts with the number 43 inside of them, and various messages of hope and support, both in English and Tagalog. While people were painting, some were having a music jam session, and others were making video messages in support of the Morong 43. The energy in the room was filled with catharsis, creativity, and hope. People left that night with a better sense of purpose in the struggle to end human rights violations, and this was done through the power of cultural work.

This event, "Art Without Barriers with Melissa Roxas", was one of the most profound moments for me and further deepened my resolve for human rights as an activist and as an artist - a cultural worker. I define a cultural worker as an artist who creates art with a purpose that is socially responsible. Cultural work is really the heartbeat of the National Democratic Movement of the Philippines, and I would extend that to any social movement in the world that is pro-people. Cultural workers have a vital role in making the message of change that is accessible to marginalized communities, through whatever artform. People may not connect with a speech or a theory-dense book on social 
change, but they will instantly connect to a song, a poem, or a visual art piece concerning social change.

One of my first introductions into cultural work was during my previous research on Filipino cultural production. Tintiangco-Cubales (2009) states, "[Critical Cultural Production] is artistic expression that is used to challenge essentialized notions of culture and identity, provide political commentary on social issues or history, create art as a form of activism, and even use art as both therapy and activism." This closely resonates with the topic of cultural work. Cultural work also brings people together in profound ways. Art has the capacity to connect people, and the art that cultural workers produce is passionately rooted in peoples' struggles and hopes (Choy, 1999; Ordonez). It has the capacity to heal, inspire, and agitate for change. Also importantly, it gives relevance to marginalized communities' struggles in ways that are accessible to them.

The title of this work is inspired by the poem Artist as Citizen, which was written by Lino Brocka, a renowned Filipino filmmaker and founder of the organization Concerned Artists of the Philippines. The final lines of this poem exemplify what it means to be a cultural worker. "The artist is a committed person, that he will always take the side of any human being who is violated, abused, oppressed, dehumanized whatever his instrument — the pen, the brush, or the camera."

This dissertation will discuss the transnational organizing of cultural workers in the National Democratic Movement of the Philippines, guided by theories of social movements and cultural work. What will also be discussed is the historical context of Filipino Migration to the U.S. and the diaspora, the history of the National Democratic 
Movement of the Philippines, the current human rights crisis in the Philippines, and my own personal connections as a cultural worker.

\section{Statement of Problem}

The proposed topic of my dissertation is Transnational Cultural Workers in the National Democratic Movement of the Philippines. The inspiration for choosing this topic comes mainly from my own experiences as a Filipino transnational cultural worker in this movement. Research has been done on Filipinos in the arts and in social movements, but not much has been done on Filipino cultural work, or rather there is a paucity of information concerning Filipino cultural work. Cultural work is a concept used by many activists who are also artists, challenging mainstream notions of what art and culture are and their purposes in society. Cultural workers define themselves as being deliberate in creating culture as an act of resistance to neocolonialism and imperialism, and much of the stories they tell though their creative work are not revealed much in literature, society, and mainstream media. This concept is also to deconstruct the myth of artists working in isolation from the community. Cultural workers are not just artists, but more importantly are community organizers who are of and with the communities, and in many ways are "popular educators" and "organic intellectuals," which I will discuss in later chapters.

\section{Background and Need}

When I began researching Filipino cultural production (Tintiangco-Cubales, 2009) back in 2003, I was coming into it as a Filipino American Hiphop dancer who saw that the majority of the dancers in the Hiphop dance community were Filipino American. I was part of a movement unofficially called the Filipino American artistic renaissance, 
which began in the early 1990s. This was a rebirth of a similar Filipino American arts movement that happened in the 1970s. Filipino Americans were exploding into the art scene as dancers, rappers, singers, and theater performers. We were telling our stories through our respective art forms, yet no one in the academic world was really taking notice, much less researching this movement. So when I first began this research, the particular scholarly works on my chosen subject was very limited.

There is a wide array of work done on Filipino American literary cultural production, namely in the forms of creative writing, poetry, and spoken word. Such works include Going Home to A Landscape: Writings by Filipinas, edited by Marianne Villanueva and Virginia Cerenio; Flippin': Filipinos on America, edited by Luis Francia and Eric Gamalinda; Babaylan: An Anthology of Filipina and Filipina American Writers, edited by Nick Carbo and Eileen Tabios; and Growing Up Filipino: Stories for Young Adults, edited by Cecilia Manguerra Brainard. These forms of cultural production have been integral in the history and culture of Filipinos. However, cultural production as resistance and liberation is also integral to this rich history and culture, and there is yet to be a comprehensive study on it. There is much to be proud of as a culture rich in talent, in writing, theater, music, and dance. It was for these reasons I decided to do research on Filipino Americans who use these art forms in performing their narratives as tools of resistance and liberation, and it is my hope that my work will lead to more comprehensive study.

When I wrote my master's thesis on the Filipino American Movement in Hiphop dance, I relied heavily on primary resources — personal interviews with my dance peers. The written sources I had were very broad, in that there were only works done on Asian 
American cultural production. By the time I finished my thesis in 2005, it was among the first of its kind.

Fast forward to 2012, I find myself again in the academic world, but this time my research evolving into Transnational Cultural Work in the National Democratic Movement of the Philippines. Within those seven years, Filipinos once again made significant impacts in popular culture. Many Filipino poets were featured on Def Poetry Jam, a spoken word showcase televised regularly on HBO. Television dance shows such as So You Think You Can Dance?, Dancing With the Stars, and America's Best Dance Crew became dominated by Filipinos. There was a significant presence of Filipino singers as contestants on American Idol. Musical acts Black Eyed Peas and Pussycat Dolls, who have members of Filipino descent, became the world's most famous bands. The viral YouTube video of 1,500+ of prisoners in the Philippines dancing to Michael Jackson's Thriller was the second most viewed YouTube video in 2007, with 15 million views. Filipino boxer Manny Pacquiao won several championships in several different weight classes. Filipino comedians became more visible on Comedy Central. And all these artists represented proudly their Filipino culture. In effect, the world took notice of Filipinos and the Philippines along with its socio-political events, and so did the academic world.

Many scholarly works and essays on Filipino artists and performers, such as Viola's Filipino American Hip-Hop and Class Consciousness: Renewing the Spirit of Carlos Bulosan (2006), Gonzalves' The Day the Dancers Stayed: Performing in the Filipina/o American Diaspora (2009), and Tintiangco-Cubales' Open the Light: Performing Filipina/o American Literature (2009), have been written in these past seven 
years, a stark difference from when I first started my research. Most of what is written is the representation of the Filipino identity in mainstream media. Much of the current and most up-to-date information on Filipino artists and performers are documented on Internet blogs and websites, such as BakitWhy.com and filamfunk.blogspot.com. Although they give thorough documentation on Filipino artists and performers in the contexts of identity, representation, and their contributions to Hiphop and popular culture, not many cover them in the context of cultural work. So once again, I find myself having to look broadly for scholarly works and connect them in the context of Filipinos and Filipino Americans. Augusto Boal's (1974) definitive work, Theater of the Oppressed, was an invaluable resource in researching cultural work. So far, the only scholar I have found that does vast work on Filipino American art as resistance is Theodore Gonzalves.

However, the lack of scholarly work on Filipino cultural work serves as a point of opportunity. While scholars are writing more about the contributions of Filipinos in popular culture, they can also use this opportunity to take this topic of interest where very few have dared to take it. Just like I did in 2005 when no one was really researching Filipino American Hiphop dancers, perhaps now this new direction of Transnational Cultural Work in the National Democratic Movement of the Philippines will attract more scholars to produce more literature about it. Because of the paucity of information concerning Filipino cultural work, this research is needed to add to the body of knowledge concerning cultural studies, art and literature, and social movements.

\section{Theoretical Framework}

The theoretical framework of this research will be based on three primary overarching theories. The first is based on Augusto Boal's (1974) Theater of the 
Oppressed, which uses art and theater produced by communities as tools of activism and organizing. Cultural workers in the National Democratic Movement of the Philippines have and continue to accomplish this in the creative pieces they create through the many mediums of art. Much of what is has happened in their lives informs the art they produce. They choose to tell their stories using art because it is a language that is very accessible to communities that have been historically marginalized. Their work has allowed spectators to become "spec-actors," becoming artists and producers themselves and begin telling their own stories, a process which Boal referred to as the poetics of the oppressed.

The second overarching theory is based on Cornel West's (1990) New Politics of Difference, whose definition of Critical Organic Catalyst is closely parallel with the definition of cultural worker. West defines this as "exemplars of what it means to be intellectual freedom fighters, that is, cultural workers who simultaneously position themselves within (or alongside) the mainstream while clearly aligned with groups who vow to keep alive potent traditions of critique and resistance" (p. 9). Cultural workers produce their cultural work not necessarily to be included in or outdoing mainstream forces. They produce their cultural work simply to give voice to themselves, usually aligned with the marginalized. Cultural work is to engage in social liberation of those within the margins of society.

The third overarching theory is based on the social movement theories of Donatella Della Porta \& Mario Diani (2006), which define social movements as distinct social processes of collective action. These processes, rather than being based on isolated actions such as rallies and mobilizations, are long-term processes. The National Democratic Movement of the Philippines defines itself as continuing the unfinished 
Philippine Revolution of 1896 , for as long as there are institutional systems that deny people their rights, there will be social movements of resistance. The National Democratic Movement of the Philippines attributes their longevity to their belief that the current oppressive system must and will fall, if not for them, then for future generations to continue the struggle.

\section{Purpose of the Study}

One of the objectives for this research is to examine the extent to which cultural work brings political consciousness to marginalized populations who do not have access to education. Another objective is to examine the impact of cultural work locally and transnationally as a tool for social change and addressing issues that impact marginalized populations, particularly in the National Democratic Movement of the Philippines, a social movement that goes beyond the borders of the Philippines.

\section{Research Questions}

Questions that led to this inquiry are as follows:

1. According to cultural workers, what is cultural work and how does it look in a transnational context?

2. How is cultural work used in the National Democratic Movement of the Philippines?

3. What are the implications of cultural work for marginalized communities?

\section{Significance of the Study}

This study on Transnational Cultural Workers in the National Democratic Movement of the Philippines will be among the first of its kind. Because of the paucity of literature and body of knowledge on Filipino cultural work, this study will add another dimension to the study of art and literature, as well as to the study of social movements 
though the arts. This study will also contribute to capturing and telling the stories of those who have been historically marginalized, particularly those of Filipino cultural workers in the Philippines and the diaspora. Thus, this study will contribute to the counter-narrative that is part of the decolonization process, a liberation from the oppressive grips of the grand narrative. 


\section{CHAPTER II}

\section{REVIEW OF LITERATURE}

The relevant literature reviewed will be divided into four sections. The first section will establish cultural work as used in Theater of the Oppressed, cultural workers defined as Critical Organic Catalysts, and examine the historical origins of Filipino theater as guerilla warfare (Boal, 1974; West, 1990; Gonzalves, 2009). The second section will examine the human rights situation in the Philippines, beginning with colonization and "miseducation" of the Filipino by Spain and the United States, as well as the current human rights crisis in the Philippines under U.S. sponsored counterinsurgency programs Oplan Bantay Laya I and II and Oplan Bayanihan [Operation Freedom Watch I and II and Operation Cooperative Endeavor] (Constantino, 1975; Karapatan, 2011).

The third section will examine the history of the National Democratic Movement of the Philippines as a social movement with a distinct social process in which the actors are engaged in collective action; the definition of National Democracy; and how it examines what it views as the three basic problems of imperialism, feudalism, and bureaucrat capitalism as the root causes of the current crisis in the Philippines (Della Porta \& Diani, 2006; Sison, 1995; Guerrero; 1970). The fourth section will examine the "waves" of Filipino migration, the Philippines as a "brokerage state" for export labor, and the bodies of Filipinos as subsidized commodities (Tintiangco-Cubales et al, 2007; Rodriguez, 2010; Tardiar 2009). 


\section{Cultural Work}

\section{Theater of the Oppressed}

Theater is a weapon. A very efficient weapon. For this reason one must fight for it. For this reason the ruling classes strive to take permanent hold of the theater and utilize it as a tool for domination. In so doing, they change the very concept of what 'theater' is. But theater can also be a weapon of liberation. For that, it is necessary to create appropriate theatrical forms. Change is imperative (Boal, 1974, p. ix).

The opening words of Augusto Boal (1974) in his Theater of the Oppressed define what it means to be a cultural worker. Cultural workers in the National Democratic Movement of the Philippines have and continue to accomplish this in the creative pieces they create, whether it is dance, spoken word, music, acting, the list of art forms can go on. Much of what is has happened in their lives is reflected in what they create.

The people of the archipelago have had a culture rich in history and art for thousands of years, and in each resistance period in the history of the Filipino people, art was always at the forefront. Whether it was through songs, chants, theater, poetry, storytelling, or dance, the message of resistance was always conveyed through art, through cultural work. In my own work as an artist and activist, and in my work with other like-minded artists and activists in the Philippines and the U.S., our work has come to be regarded as cultural work rather than just simply art and literature, and therefore we regard ourselves as cultural workers.

For cultural workers, cultural work is the use of the various forms of art with the purpose of social change. Furthermore, they push for a reclaiming and redefinition of culture that has been smothered and silenced by the avalanche of Western imperialism. As E. San Juan argues in Nerferti X. M. Tadiar's (2009) Things Fall Away: Philippine Historical Experience and the Makings of Globalization, 
These heterogeneous projects of resistance and revolt, inscribed in poems, stories, testimonios, and other performances of those formerly silenced and made invisible, are what ultimately reproduce the "Third World" as a permanent political-cultural agency of global transformation...these performances can be used to fashion emancipatory constituent subjects who are equipped with 'a memory of the future,' a recollection of hopes and dreams from which the future is extrapolated (p. 4-5).

Cultural workers choose to tell their stories through art because it is a language, one that is most accessible to marginalized communities. Boal (1974) knew the importance of this in the fight for liberation. "Each language is absolutely irreplaceable. All languages compliment each other in achieving the widest, most complete knowledge of what is real" (p. 121). This rang true in the program in Peru called Integral Literacy Operation (Operación Alfabetización Integral [AFLIN]), which Boal (1974) discusses. The principal aims of AFLIN were:

1) to teach literacy in both the first language and in Spanish without forcing the abandonment of the former in favor of the latter; 2 ) to teach literacy in all possible languages, especially the artistic ones, such as theater, photography, puppetry, films, journalism, etc. (p.121)

Like the principal aims of AFLIN, cultural workers in the National Democratic Movement of the Philippines engage in a wide variety of artistic languages, and their message has been widely accessible due to the fact that it has grown into an artistic movement. Their work has allowed spectators, both Filipino and non- Filipino, to become artists and producers themselves and begin telling their own stories and collective struggles. This is what Boal (1974) referred to as the poetics of the oppressed.

The poetics of the oppressed is essentially the poetics of liberation: the spectator no longer delegates the power to the characters wither to think or act in his place. The spectator frees himself; he thinks and acts for himself! Theater is action! (p. 155) 


\section{Cultural Work/Worker Defined}

In the literature that tackles cultural work, few mention the actual terms cultural work and cultural worker. Those that do actually mention these terms define them quite differently from what they mean in social movements such as the National Democratic Movement of the Philippines. Banks' (2007) work The Politics of Cultural Work is one example. He states that cultural workers are those involved in the production of aesthetic goods and services. In other words, he defines cultural work as an occupation in mainstream popular culture, rather than as a political activist who uses art and literature to create a culture of resistance. Thus, the very title of his work can be quite misrepresentative of cultural work in the context of political action and social movements. A direct critique of this definition of cultural worker, in the context of "art for art's sake," is that although the art being produced can generate capital, the essence of it is meaningless. Jonathan Beller tackles this notion of art in a conversation with Neferti X. Tardiar (2008) in her work Cultural Revolution Internationale? "Record prices for Pollock's, Rothko's and Warhol's - the emptiest art imaginable - testify to the liquidation of art as content, and the apotheosis of art as fetish" (p. 44).

Cultural workers are much more than the art they create, and to take it broader, artists are much more than their art as their occupation. As with the title of this study, the artist is a citizen. Resonating with Lino Brocka, Zinn (2003) shares the same definition of the role of the artist.

But the artist can and should do more. In addition to creating works of art, the artist is also a citizen and a human being... So the word transcendent comes to mind when I think of the role of the artist in dealing with the issues of the day. I use that word to suggest that the role of the artist is to transcend conventional wisdom, to transcend the word of the establishment, to transcend the orthodoxy, 
to go beyond and escape what is handed down by the government or what is said in the media (p. 2).

By being transcendent, cultural workers fulfill their patriotic role as citizens and the art they produce is a political act, literally and figuratively.

Cultural workers engage in political action, as Boal mentions that all actions of man are political. By doing so, they are participating in defining and redefining what it means to be a cultural worker, in what Cornel West (1990) discusses as the new cultural politics of difference. West describes this new cultural worker in his essay The New

\section{Cultural Politics of Difference.}

A new kind of cultural worker is in the making, associated with a new politics of difference. These new forms of intellectual consciousness advance new conceptions of the vocation of critic and artist, attempting to undermine the prevailing disciplinary divisions of labor in the academy, museum, mass media, and gallery networks while preserving modes of critique within the ubiquitous commodification of culture in the global village (p. 1).

These new cultural workers create and produce not to be included in or outdoing mainstream forces. Rather, they create and produce simply to give voice to themselves, usually aligned with the marginalized. Resonating with West, their work is to engage social liberation and empower those in the margins of society, because for too long they have been kept outside of the master narrative, and if they are mentioned in the master narrative, it is those in power who are telling the stories of the marginalized, rather than the marginalized telling their stories themselves.

The new cultural politics of difference are neither simply oppositional in contesting the mainstream (or malestream) for inclusion, nor transgressive in the avant-gardist sense of shocking conventional bourgeois audiences. Rather, they are distinct articulations of talented (and usually privileged) contributors to culture who desire to align themselves with demoralized, demobilized, depoliticized, and disorganized people in order to empower and enable social action and, if possible, to enlist collective insurgency for the expansion of freedom, democracy, and individuality (p. 1) 
West (1990) also points out that this new kind of cultural work comes out of a time of crisis, whether it be economic, social, racial, or a few of or all these together.

There can be no artistic breakthrough or social progress without some form of crisis in civilization - a crisis usually generated by organizations or collectivities that convince ordinary people to put their bodies and lives on the line (p. 2).

In order for communities to be engaged in social change, artists and cultural workers must be brave enough to lead and take risks in making their stories and messages accessible to marginalized communities so that they can be inspired to do the same.

In creating and producing as ways of promoting the new cultural politics of difference, cultural workers become what West calls Critical Organic Catalysts. They take the best of what popular culture has to offer and then flip it by creating subcultures of criticism.

The most desirable option for people of color who promote the new cultural politics of difference is to be a Critical Organic Catalyst. By this I mean a person who stays attuned to the best of what the main stream has to offer-its paradigms, viewpoints, and methods - yet maintains a grounding in affirming and enabling subcultures of criticism. Prophetic critics and artists of color should be exemplars of what it means to be intellectual freedom fighters, that is, cultural workers who simultaneously position themselves within (or alongside) the mainstream while clearly aligned with groups who vow to keep alive potent traditions of critique and resistance. In this regard, one can take clues from the great musicians or preachers of color who are open to the best of what other traditions offer, yet are rooted in nourishing subcultures that build on the grand achievements of a vital heritage (p. 9).

Filipino artists and cultural workers have created subcultures of criticism in many forms of popular culture — spoken word collectives, multi-genre performance theater collectives, MC rap groups, rock bands, jazz bands, martial arts, the list goes on. In this current time of social crisis in the Philippines in which we see widening gaps of the class divide, the tasks for these new cultural workers West describes come with great 
urgency. Through the work they create and produce, they are giving voice to the stories

of those who have long been disenfranchised.

The time has come for critics and artists of the new cultural politics of difference to cast their nets widely, flex their muscles broadly, and thereby refuse to limit their visions, analyses, and praxis to their particular terrains. The aim is to dare to recast, redefine, and revise the very notions of 'modernity,' 'mainstream,' 'margins,' 'difference,' 'otherness.' We have now reached a new stage in the perennial struggle for freedom and dignity (p. 10).

Tadiar (2008) takes cultural work further in that art is a dominant creative practice in the sense of cultural revolution, and to echo West, to understand marginalization as a site of resistance and a catalyst for liberation.

I would want to retain a sense of 'cultural revolution'...that understands it as the longue durée of transformations in the social imaginative and creative capacities and practices that human beings engage in as part of the process of making their lifeworlds, as part of living. This sense, I think, might enable us to better think about what and where the margins are, and what resistance looks like (p. 42).

Cultural workers engage in work to create a culture that constantly challenges the status quo. Since change is constant, the very practice of cultural work is a constant process of world transformation (Tadiar, p. 45).

\section{Filipino Cultural Work}

Filipinos have been using art and performance as resistance for centuries, from the Philippines to the United States and the diaspora. They have been the Critical Organic Catalysts West describes and practicing Boal's poetics of the oppressed even before Boal coined the idea. Prior to the "seditious plays" (to be discussed later) Filipinos mounted during the U.S.-Philippine war at the turn of the $20^{\text {th }}$ century, the seeds of the movement for national democracy were planted during the twilight of Spanish colonization in the Philippines through the writings of Dr. Jose Rizal and the Propaganda Movement. 
Jose Maria Sison is a Filipino revolutionary writer and cultural worker who has authored several works on the history of the national democratic struggle, U.S. imperialism, and globalization. He is the founder of the radical youth and student organization Kabataang Makabayan (Patriotic Youth) in 1964, as well as founder of the Central Committee of the Communist Party of the Philippines in 1969, which organized its armed wing, the New People's Army (NPA) in waging armed struggle against the government of President Marcos. He along with many activists were forced to go underground when Marcos declared martial law in 1972, during which he was captured and detained as a political prisoner. During his detainment, he wrote many revolutionary poems, which is collected in his work Prison and Beyond. He was released shortly after the People Power Uprising of 1986, which overthrew President Marcos. However, the subsequent Aquino administration, and every president afterwards, still deemed him as a threat to the government, and since then, Sison has lived in political exile in the Netherlands, where he continues his anti-imperialist work. Currently he is the chairperson of the International League of Peoples' Struggle [ILPS] and chief political consultant of the National Democratic Front of the Philippines [not to be confused with the National Democratic Movement, a distinction which will be later discussed].

Sison recounts the early period of cultural work, the time of Rizal and the Propaganda Movement, as an act of anti-colonialism and the beginnings of a national democratic cultural revolution, in his speech The Need for a Cultural Revolution (1966).

The two novels [Noli Mi Tangere and Filibusterismo], and his essays, the "Indolence of the Filipinos" and "The Philippines A Century Hence," were written in furtherance of a national democratic cultural revolution. It was a revolution in the sense that it contraposed national culture to the colonial culture of which the friars were the chief defenders. It was in this same spirit that the participants of the Propaganda Movement wrote as Marcelo H. del Pilar did, 
orated as Graciano Lopez Jaena did and painted as Juan Luna did. All of them exposed the exploitation and brutalization of our people, thus paving the way for the clear call for separation from Spain by the Katipunan (Sison, 1966).

The Katipunan was a separatist movement that waged a revolution for the independence of the archipelago from Spain, known as the Philippine Revolution of 1896. This was the beginning of the National Democratic Movement of the Philippines, calling for a national democratic culture that integrated democratic concepts with indigenous conditions (Sison, 1966).

The emergence of that national culture was essentially a political phenomenon; a national culture arose in direct and necessary opposition to the colonial and clerical culture which exploited and brutalized our people. An awareness of national culture spread among the Filipino people as fast as national sentiment and consciousness spread among them. The political awareness of a national community reintegrated the cultural patterns in the provinces, surpassing both the magical barangay culture of pre-Hispanic times and the feudal Christian culture under Spanish domination. The desire for a modern national democratic society outmoded the feudal society developed by the conquistadores from the primitive rule of the rajahs and the datus who submitted themselves as local puppets of the foreign dispensation (Sison, 1966).

However, the movement for a national democratic culture would be frustrated with the transfer of power from Spanish colonization to U.S. imperialism. Just as it was used to resist and fight against the Spanish, cultural work would continue to be used to wage war against U.S. imperialism. Theodore S. Gonzalves (2009) discusses this history of Filipinos and cultural production as resistance and liberation in The Day the Dancers Stayed: Performing the Filipino/American Diaspora. He begins his book by recounting the events of the staged war in the Philippines between the United States and Spain in 1898 , used by the two warring countries as a front to conceal what was really going on without the knowledge of the people of the Philippines-Spain was selling the Philippines, Guam, and Puerto Rico for \$20 million. The Filipino revolutionaries were 
already fighting for their freedom from their Spanish colonizers, and winning. Rather than be humiliated in front of the world as losing the war to a bunch of "indios," "savages," and "monkeys," Spain ceded the Philippines to the United States, who at the time was becoming a major world power.

But the Filipinos would not be taken over by another colonizer, and so began the Philippine-US War, in which millions of Filipinos fought and died. U.S. President Theodore Roosevelt formally ended the war on July 4, 1904, but battles continued to be fought by Philippine guerillas outside the metropoles of the country for more than ten years. Gonzalves (2009) recounts that during this time, "seditious plays" became a form of guerilla warfare, in violation of the Sedition Act, which made utterances and actions in support of Philippine Independence a crime.

The plays were as 'vital and immediate as a call to arms.' Playwrights, actors, stagehands, and audience members risked arrest, imprisonment, and fines by working on and attending the plays... The plays, written and performed in Tagalog, were a hit among the masses...because the authors, often of modest means themselves, used popular theatrical conventions and forms, as well as their knowledge of popular culture, to create set and costume design, deep cultural references in the text and lyrics, and other devices that conveyed subversive meaning (p. 4)

These performances, along with the "performance" war between U.S. and Spain, marked a significant point in history for Filipino cultural workers, taking place "at the intersection of combat and cultural production, when a mock battle was answered by a seditious play" (p. 5). Gonzalves may have been influenced by Boal in the way he interpreted the seditious plays as weapons of liberation and poetics of the oppressed. In telling these stories through performance, cultural workers must make the message accessible to broader communities. Staying attuned with popular culture is a way of assuring that accessibility. Gonzalves (2009) states that popular culture is not only 
synonymous with resistance, but is "has been and continues to be a place of possibility, one of the grounds on which struggle may be waged" (p. 19). Cultural workers see this as especially important to realize. To do otherwise is what cultural workers believe as giving consent to a system that represses and oppresses communities.

The struggle for national democracy in the Philippines did not end with the Propaganda Movement and the subsequent Philippine Revolution. Senator Claro M. Recto, a staunch anti-imperialist, was one of the first to express the need for a second propaganda movement in 1960. Sison (1995) echoed this sentiment in his speech "The Tasks of the Second Propaganda Movement," which is included in his work The Struggle for National Democracy.

It is important to speak of the Second Propaganda Movement because we need to recall the unfinished tasks of the Philippine revolution. The Second Propaganda Movement is required to arouse our nation anew to the struggle for the fulfillment of the national democratic tasks of the Philippine revolution... The Second Propaganda Movement is first of all a political movement. It is an educational movement with political aims; for after all there is no type of education or culture that is detached from politics (pp. 92-93).

Sison asserted that the Second Propaganda Movement learn from the people and their conditions before teaching them what to do, and because the people are the ones experiencing oppression firsthand, they are the main experts of their situation. This is a form of Boal's poetics of the oppressed, in building a social movement towards victory. "The Second Propaganda Movement is a mass movement in the most genuine sense with the mobilization and victory of the masses as the main objective" (p. 93).

For cultural workers, the Second Propaganda Movement, beginning in the 1960's up to today, is in essence cultural work in the National Democratic Movement of the Philippines. Cultural workers believe cultural work is at the forefront of this movement, 
using the arts and literature produced by cultural workers that are based on the concrete conditions of marginalized communities. In doing so, cultural workers convey the message of social change in ways that are accessible to marginalized communities and thus mobilizing them to advance this movement. Cultural workers view this movement as a cultural revolution that will realize the original Philippine Revolution's aspirations for national democracy. Sison (1995) stressed this aspect of cultural work.

In literature and the arts, the process of raising aesthetic standards and popularization should go hand in hand. For the masses who constitute our biggest audience can appreciate our literature and art only if our writers and artists make use of the life and struggles of our masses as raw material. If we adopt this raw material, it can be given the form that our artistic talents are capable of making...In the present era, one must unswervingly take the proletarian standpoint in order to achieve the greatest progress in art and literature. Literature and the arts should reflect the revolutionary struggle and point towards its triumph...The Second Propaganda Movement should be a thoroughgoing cultural revolution. It should shatter the present semicolonial and semifeudal superstructure. A new national and democratic culture is crying out to be born (pp. 98-101).

History seemed to repeat itself in the Philippines with the brutal silencing of critics and activists, and cultural workers engaging in underground guerilla seditious plays, when President Ferdinand Marcos declared martial law in 1972, which will be discussed in detail later. Although forms of journalism and film that were critical of the dictatorship were banned, the conditions were ripe for disseminating alternative points of view to the people. Cultural workers once again took on the role of Critical Organic Catalysts engaging in poetics of the oppressed in the form of Philippine political theatre. Van Erven (1987) recounts this new era of "seditious plays" in Philippine Political Theatre and the Fall of Ferdinand Marcos.

Theatre became the best medium for spreading alternative points of view. Also, people's theatre workshops, conducted throughout the archipelago, increased the political awareness of urban poor, farm workers, unemployed, or striking factory 
laborers and students. An impressive network of more than 300 community-based theatre groups helped channel the creativity and frustration of the oppressed Filipino people (p. 58).

Because of the brutal suppression of the Marcos dictatorship, many activists had to operate underground, some taking on the armed struggle by joining the New People's Army [NPA], a Maoist revolutionary armed resistance against the reactionary government that continues to wage people's war to this day. Membership in the NPA swelled to the thousands during the dictatorship. While waging armed struggle in the countryside in defending communities most directly oppressed by the government, the NPA has also recognized the power of theatre. For many years the NPA has operated socalled "Armed Propaganda Units" in areas that are more or less under their control (p. 60). Their performances give the NPA an opportunity to befriend the local population and explain their revolutionary ideology. They also explain to the peasants the economic causes of their poverty and, through Boal-like theatrical workshops, help them to prepare for verbal confrontations with landlords or officials (p.60). In many ways, the Armed Propaganda Units of the NPA engage in poetics of the oppressed with the peasant communities.

Although there were more than 300 people's theatre groups that were opposed to the Marcos regime and continue to be critical of subsequent governments, it is incorrect to say that they all adhere to a revolutionary Marxist ideology.

The groups are united, however, in the belief that their type of theatre should help liberate oppressed people. The actors are not so much performance oriented as process oriented, and they no longer call themselves actors but "ATORs"Artists-Teachers-Organizers-Researchers - to signify their change of attitude from individualistic, career-oriented performers to artists totally committed to stimulating creative activity on the grassroots level (p. 60). 
The "ATORs" are in essence cultural workers, committed to social change through the art they produce with the community.

After the assassination of Marcos' most vocal opposition, Senator Benigno "Ninoy" Aquino, Jr. on August 21, 1983, the Filipino people, namely the apolitical and complacent middle class, had enough of Marcos' brutal government and engaged in mass struggle, or what many activists call the "parliamentary of the streets." Filipinos took to the streets and participated in large-scale rallies and mobilizations not seen since the rallies and mobilizations against Marcos during the First Quarter Storm of the early 1970's. Always keen to the social conditions, cultural workers came out of the underground and became more daring in the work they produced during this time.

After Benigno Aquino, Jr., was assassinated, theatre took on an even bolder role. The many rallies and demonstrations since that time have featured improvisations, street plays, tableaux, and political satires staged in parks, on streets, on makeshift stages, and at the wake of a murdered labor leader while ambulant and in procession (Fernandez, 1987, p. 112).

To be a cultural worker in the Philippines, as with being an activist, is a dangerous undertaking. Harassment, detainment, torture, enforced disappearance, and extrajudicial killings of activists and civilians defined the Marcos dictatorship, and despite the overthrow of Marcos in the People Power Uprising of 1986, subsequent regimes have continued this brutal culture, and in many ways surpassed the human rights violations record of Marcos. Because of this, activists and cultural workers in the National Democratic Movement of the Philippines are hesitant to call the overthrow of Marcos what mainstream media and scholarship calls it, the People Power "Revolution." Revolution implies significant change in society, but as the human rights record of subsequent regimes after Marcos show (which will be discussed at length later), not much 
has really changed. For this reason, activism and cultural work continue to be of vital significance and relevance.

The battle for liberation is far from over. After a decade-and-a-half of cultural work, [cultural workers] became a leading force in the people's movement that finally succeeded in deposing the dictator on 25 February I986. But as long as there are fascist warlords, private army gangs, and hordes of starving people, there will be a need for people's theatre to expose the ills of society and to lend a voice to the oppressed (p. 76).

When discussing cultural work in the National Democratic Movement of the Philippines in the Philippines, it is hard not to include the work of legendary filmmaker Lino Brocka. A prolific artist, he made over 50 films during his career. His films crossed many genres, from melodrama, to noir, to neo-realism. But he is best known for his agit-prop (agitation propaganda) films, which were scathing political critiques of the Marcos dictatorship. This is notable because of heightened media censorship under Marcos.

Maynila: Sa mga Kuko ng Liwanag (Manila: in the Claws of Neon) (1975) is a film about a provincial boy who goes to Manila in search of his love who was deceptively recruited into a brothel. In his search, he gets pulled into the downward criminal spiral of Manila's slums. This film, though not as subversive as his later films, was Brocka's critique of the poverty and underground economy the government was putting its citizens in. One of his more subversive films was Bayan Ko: Kapit sa Patalim (My Own Country: Clutching at Daggers) (1983). The title was in reference to the popular protest song, Bayan Ko, which was sung at many anti-Marcos rallies. It is about an exploited printing press worker struggling to provide for his wife and newborn child, eventually compelling him and his coworkers to forcefully take over the printing factory in a strike. This film was subversive enough to have Brocka stripped of his Philippine citizenship by Marcos (Digo). But perhaps his most subversive film was Orapronobis (Fight for Us) (1989), 
which portrayed the abuses of the military and religious cults it had recruited in the antiinsurgency war in the countryside (Digo). The film is possibly the only film to explicitly condemn the administration of the extremely popular Cory Aquino, who became president as a result of the People Power uprising, which toppled Marcos in 1986.

Brocka often shot his films at night, because during the daytime, he was busy organizing and participating in anti-government rallies. His activism was reflected in the films he made. His activism also led him to form the Concerned Artists of the Philippines [CAP] in 1983. His stand was that artists were first and foremost citizens and, as such, must address the issues confronting the country. CAP's activities promote arts and culture that are relevant to the people and their conditions, in order to countervail the onslaught of globalization and remnants of feudalism. The organization works with different sectors of society in the struggle for the people's political and economic liberation (Concerned...). CAP, which was one of the organizations that gathered at then Manila International Airport to welcome Benigno "Ninoy" Aquino from his self-exile in the United states, became active in anti-government rallies in both Manila and the provinces after the Aquino assassination. It also figured prominently in protest actions against media censorship.

As an artist, Brocka was a true cultural worker in the National Democratic Movement of the Philippines. His art and work with CAP had purpose and responsibility to communities most marginalized by government and the elite. His influence can be seen in the films by independent filmmakers who are part of the National Democratic Movement of the Philippines, such as those in film organizations like Southern Tagalog Exposure and Sine Patriyotiko (Patriotic Films). 
Cultural workers view cultural work as the forefront of the National Democratic Movement of the Philippines. Cultural workers play a vital role in addressing to problems in society and making them accessible to the very people who are oppressed by these problems, giving them the agency to also understand and confront systems of oppression. For as long as these systems of oppression exists, these Critical Organic Catalysts will continue their "seditious plays" and engage in poetics of the oppressed with marginalized communities.

[Cultural work] has concerned itself with the ideas and problems of present-day Philippine reality, giving dramatic flesh and bones to such abstract terms as imperialism, injustice, oppression — and, finally, liberation. Its power has come from involving its audience in the protest and in the victory by asking them to decode the meaning, make the inferences, draw the conclusions, and carry the plays out of the theatre and into their streets and homes. Creative poverty and protest have made for eloquent theatre - both of protest and of liberation (Fernandez, 1987)(p. 113-114).

In the next section, the human rights situation in the Philippines will be discussed in historical context, to give a fuller understanding of the social and political conditions that have and continue to inform the work of cultural workers in the National Democratic Movement of the Philippines.

\section{Human Rights in the Philippines in a Historical Context}

\section{Miseducation and Decolonization in the Philippines}

Beginning in the mid-1500s, the archipelago now known as the Philippines became one of several sites around the world for Spanish colonial expansion. With the exception of the southern portion of the islands, which already had a strong Islamic civilization that waged successful resistance to colonial rule, establishing the islands as a colony of Spain was accomplished in two ways: first being the violent imposition of Catholicism that had decimated the local indigenous cultures and the second being the Spanish education 
system. The archipelago, now called the Philippines, and the colonized people, now called Filipinos — both named after King Philip II of Spain, were conquered two-fold, as a whole by the Catholic religion, and further divided by the education system that was reserved only for the elite class of Filipinos, those who found favor with the Spanish colonizers. This elite class of Filipinos were called the Illustrados, and were also able to travel to schools in Europe for further education. Education drove a deep wedge between the Illustrados and the rest of the local enslaved population, called Indios by their colonizers. Education was used by the Spanish colonizers to divide and conquer the Filipinos for the next 300 years.

However, education also proved to be a catalyst for the Philippine Revolution in the late 1800s. Dr. Jose Rizal, a well-educated Filipino, was among the most prominent figures of the Propaganda Movement, formed in 1872. The Propaganda Movement comprised of educated Filipinos who wrote about and exposed the abuses of Spanish rule in the Philippines. While critical of Spanish rule, the Propaganda Movement called for reforms in government in which Filipinos were treated equally. Noli Mi Tangere (Touch Me Not) and El Filibusterismo (The Filibuster) were the two works by Rizal that exposed Spanish abuses in government and religion. These works were deemed subversive enough that caused Rizal's subsequent arrest and execution. His works inspired the formation of the revolutionary organization, the Katipunan, founded by Andres Bonifacio. The Katipunan, comprised mostly of the peasant class, waged a successful revolution against Spain. Ironically, Rizal only called for reforms within the Spanish governance of the Philippines, but his works inspired an armed revolution he never 
intended to happen. Education was out of reach for the peasant class, yet it was a few like Bonifacio and the Katipunan who were literate enough to mobilize them for revolution. The victory of the Philippine Revolution over the Spanish in 1898 was short-lived, if not outright stolen, by a new colonizer in the form of the United States. This was also the time of the Spanish-American War, in which Spain was losing its place as a major world power. Rather than accept a humiliating defeat by the Filipinos, Spain ceded the Philippines, along with Guam and Puerto Rico, to the United States for \$20 million, all without the knowledge of the Filipinos. The Americans presented themselves to the Filipinos as their "saviors" from the evils of Spain, but in reality became their new colonizers. This in turn began the Philippine-American War, which is recorded to have lasted between 1899-1902, but accounts of guerilla resistance, especially in the Muslim areas of Southern Philippines, indicate that the war lasted well into 1913. This war was called the Philippine Insurrection, in which millions of Filipinos were killed by the Americans. It served as a precursor for the wars the United States had with Vietnam and Iraq.

Among the scorched-earth policies of General Jacob H. Smith were "kill everyone over the age of ten" and make the islands "a howling wilderness." Of particular note is the indiscriminate killing of Filipinos over the age of ten for two reasons. First is that a Filipino over the age of ten is able to carry a weapon and fight. Second is that a person over the age of ten is able to remember. For the remaining population under the age of ten with now very moldable minds, another policy would be placed upon them, the introduction of the American public education system, education that was denied to the peasant class of Filipinos by the Spanish. After the war, American education became the 
single most powerful tool of colonization and "miseducation" of the Filipinos for the next 100 years and up to today.

Renato Constantino, the most highly regarded Filipino nationalist educator, discusses American education as a tool of colonization in two of his definitive works, The Miseducation of the Filipino (1968) and The Philippines: A Past Revisited (1975). In what he calls the "pacification through education,"

Miseducated Filipinos invariably regard as one of the unqualified benefits of American colonial rule was the rapid introduction... of the public school system. They point to the early efforts to put up schools as evidence of the altruistic intention of the United States government. On the contrary, what initially spurred the establishment of the public schools was the conviction of the military leaders that education was one of the best ways of promoting the pacification of the islands (Constantino, 1975, p. 314-315).

Many Filipinos saw this as an attractive opportunity, because what was once just reserved for the elite upper class, education was now free and compulsory for all people. The peasant Filipinos thought now they would be treated as equals to the Filipinos of the upper class. However, reflecting back to the insurrection policy of General Smith, the public school system was nothing more than a program to control the newly conquered people. Militarism and education were one and the same during American colonial rule of the Philippines. In addition to military officers being the new teachers for the Filipinos, six hundred Americans were brought in from the United States as teachers, principals, and supervisors, to provide the correct foundation of the education system (Constantino, 1975, p. 316).

Furthering the pacification of the Filipinos, the pensionado program was implemented. Under this program, selected Filipinos were brought to the United States to study at American universities. 
This initial advantage enabled them to rise to positions of influence in colonial society, a fact that maximized their utility to the colonial power. Not only did they transmit the ideas they had imbibed from their American education, they could be pointed out as examples of the advancement made possible by American benevolence (Constantino 1975, p. 316).

This would pave the way for neo-colonialism, a form of imperialism in which the U.S. no longer has to physically be in the Philippines to carry out its colonial policies, because they have molded the minds of those in Philippine government to do it for them. Despite gaining independence from the U.S. in 1946, activists view the Philippine government as still subservient to U.S. interests in the country, especially in its immense wealth of natural resources.

Within the use of education as colonization was the use of English as the medium of instruction. Filipinos began to learn not only a new language, but a new culture as well. This would lead to the loss of language and the loss of culture, in favor of everything American.

Education became miseducation because it began to de-Filipinize the youth, taught them to look up to American heroes, to regard American culture as superior to theirs and American society as the model par excellence for Philippine society. These textbooks gave them a good dose of American history while distorting, or at least ignoring, their own (Constantino, 1975, p. 318).

This colonial mentality continues to this very day, even with the Philippine constitution stating that the medium of instruction in education and governmental affairs is to be done in English. Although Filipino (Tagalog) is considered the national language, English is still heavily used. It is also another wedge of divide between classes. To be able to speak English means that one is educated, while a lack of English proficiency means that one cannot afford to go to school. 
The Americans never underestimated the power of education as a tool of conquest. Constantino regards this as more powerful than physical and violent means of conquest.

The most effective means of subjugating a people is to capture their minds. Military victory does not necessarily signify conquest. As long as feelings of resistance remain in the hearts of the vanquished, no conqueror is secure...The moulding of men's minds is the best means of conquest. Education, therefore, serves as a weapon in wars of colonial conquest (Constantino, 1982, p. 2).

An example of physical conquest being less effective is the Japanese occupation of the Philippines during the World War II. Although the Japanese military raped and decimated the Philippines, it could not exert its political influence into the minds of the Filipinos like the Americans did with education. Through education, Philippine foreign policies developed into complete subservience to the U.S. and foreign multinational corporations. And because of this, the immense wealth of natural resources are not nationalized, but owned by foreign investors in unilateral trade agreements that do not benefit the Filipinos as a nation, but only the few rich and powerful ruling class.

Despite education used as a means of conquest of the Filipino people, Constantino recognized the emancipatory power it also wields. The 1960s saw a surge of nationalism and a growing social movement against imperialism in the Philippines, as with other antiimperialist movements happening in other parts of the world at that time. Influenced by Senator Claro M. Recto, a staunch Philippine nationalist and harsh critic of U.S. interests in the Philippines, Constantino and other educators and scholars began to push for a nationalized culture in the Philippines through a new form of education. This was also the time he wrote The Miseducation of the Filipino, a scathing critique of American education in the Philippines and a call for a re-education of the Filipino in reclaiming 
their cultural identity and histories, a rewriting of history from the perspective of the Filipino.

Education is a vital weapon of a people striving for economic emancipation, political independence and cultural renaissance. We are such a people. Philippine education therefore must produce Filipinos who are aware of their country's problems, who understand the basic solution to these problems, and who care enough to have courage to work and sacrifice for their country's salvation (Constantino, 1982, p. 1).

It can be seen here that Constantino may have been influenced by Paulo Freire, regarded as the godfather of critical pedagogy who also believed in education as a tool of liberation. It can also be seen here that this is a direct influence in the rise of the First Quarter Storm, a period of large-scale protests and marches against the corruption and self-serving Philippine government as well as the failing economy. This was led by the radical youth \& student organization Makabayan (Patriotic Youth). The sentiments of the First Quarter Storm echoed Constantino, whose participants were aware of the nation's problems and risked their lives to save it, a clear indication of nationalism. The First Quarter Storm led the U.S.-supported presidency of Ferdinand Marcos to declare martial law in 1972, forcing this social movement to go underground. During martial law, Marcos ruled the Philippines as an iron-fisted dictator, jailing his political opponents and executing political dissidents. However, the membership of the armed underground nationalist movement grew to 16,000 by the time of Marcos's ouster through the bloodless People Power Uprising in 1986.

The miseducation of the Filipino, and the subsequent subservience of Philippine government to U.S. imperialism through brutal oppression, are results of what Constantino refers to as "an avalanche of western cultural materials" (Constantino 1982)(p. 18). He believed that what is most needed is an education of the Filipino by the 
Filipino in order for them to truly be free. This is motivated by the rich tradition of collective struggle in Philippine history that has been glossed over or ignored completely through colonization. As Constantino states,

Participation in mass actions raises the level of consciousness in the masses. The more conscious they are, the more they become active and the more telling their contribution to the changing of society and the changing of their own attitudes, until they come to realize that struggle is their historic right and it alone can make them free (Constantino, 1975, p. 10-11)

A broad social movement is vital to meeting this urgent need. Through social movements, like the Katipunan, the First Quarter Storm, and People Power, the participants become the educators and education becomes a tool of liberation.

Though colonization and globalization has molded the minds, bodies, and cultures of the Filipino people for centuries, a decolonization movement to reclaim the culture that was dismembered and lost has been burgeoning among Filipino scholars, activists, and cultural workers. This process of remembering and "re-membering" is not an easy task, as Homi K. Bhaba states, "Remembering is never a quiet act of introspection or retrospection. It is a painful re-membering, a putting together of the dismembered past to make sense of the trauma of the present." The trauma Bhaba speaks of is what Strobel calls "cultural amnesia," which is the result of the violent blunt-force trauma of colonization.

For a long time, I suffered from cultural amnesia. I was unconscious about my cultural heritage. I thought I belonged to a tribe called "little brown sisters" ruled by the "big white masters." the masters gave me their tongue, their ideas, their music, art forms, and their religion. They said the world I come from was dark, full of evil spirits, and they had brought the light with them to chase the ghosts away. With this light, they also chased away my memories. They said they had a divine right to conquer us and make us more human by cleaning up our slate and write new thoughts on it. And so without memories, I forgot who I was. I became a good colonial child. I became well-mannered, genteel, and civilized (Strobel, p. 12). 
Through colonization, the Filipina, both herself and the nation she symbolizes, is forced to forget her history and is dismembered from her culture, and is instead given a new identity to suit the needs and standards of the colonizer.

Strobel defines decolonization as "a process of learning to love one's self again, of seeing one's self as important enough to think and write about, of learning to face the truth and learning to tell the truth" (Strobel, p 50). While the colonial past is painful and traumatic, nothing is going to change that and it needs to be remembered to make sense of the present in order to build for the future. Strobel refers to these three moments in time as occurring simultaneously in the process of decolonization. "Decolonization means to reconnect with the past in order to understand the present and to be able to envision the future. These three - past, present, and future—on another level of consciousness co-exist simultaneously" (Strobel, p. 118). Decolonization, through personal histories as counter-narratives to the grand narrative of colonization, is a form of resistance. It is a courageous act of remembering, rewriting, and reclaiming of cultures and histories that colonization took away. "Decolonization is a process that makes the mythical and historical past available to the present. Cultural and historical knowledge, language, and personal histories recovered through memory makes the re-writing of the self possible within a decolonized framework" (Strobel, p. 118).

Strobel constructed a framework of decolonization based on dialogues she had with the participants in her research. It is influenced by Paulo Friere's pedagogy of Naming, Reflection, and Action.

Naming

- To decolonize is to be able to name internalized oppression, shame, inferiority, confusion, anger; 
- To decolonize is to acquire cognitive knowledge about [one' culture and history;

- To decolonize is to understand the meaning of "loss of cultural memory" and its consequences;

- To decolonize is to heal the self, heal the culture:

Reflection

- To decolonize is to develop the ability to question one's reality as constructed by colonial narratives;

- To decolonize is to understand the need to recover memory;

- To decolonize is to ask: Where do I go from here?

Action

- To decolonize is to decide to give back to the community;

- To decolonize is to learn to question;

- To decolonize is to tell and write one's story, that in the telling and writing, others may be encouraged to tell their own.

Although this is not the exhaustive list of Strobel's decolonizing framework, the ones aforementioned reflect the coexistence of the both the indigenous and the traumatic past, the present state of the individual and community, and the possibilities of a decolonized future. It encourages the colonized to do and act on things that have the colonizer has forbidden them to, a courageous act of resistance.

Along with decolonization is the movement for nationalism, to be proud of a rich history and culture and to tell it from the people's point of view, not from the grand narrative of the colonizer. One of the most effective ways of colonizing the minds of the Filipinos was the education systems of the Spanish and the Americans. The Philippines, and in particular the Filipina, has become miseducated. They were taught to forget the powerful roles of the babaylans and instead view them as witches and heathens, see Gabriela Silang and Tandang Sora as mere blips in the radar of history books, and view their dark skin and coarse hair as filthy and ugly—and strive instead to emulate the beauty and passivity of Maria Clara. 
Through cultural work, the process of decolonization becomes one that is creative and liberatory. It is the reclaiming of the Philippine indigenous past, remembering the traumatic colonial past, understanding the cultural crisis of the present—all to build emancipatory possibilities of the future, that makes the process a powerful and courageous act of resistance. As Strobel states, it is the "process of learning to love oneself again," both individually and collectively, despite what Tardiar (2009) described as the colonizers' "prostitution of the Philippines,"- - her body, her image, her community, her nation. The time has come for the Filipina, both herself and her nation, to reclaim the creative powers of the babaylan and shed away the colonizer-imposed illusionary symbol of Maria Clara, for the struggle and survival of the history and culture of the Philippines.

The emergent culture of struggle of the colonized would consist of the process of freeing into expressivity the whole range of social life that colonialism impeded, if not obliterated. Culture was this process of creative restitution and expressive action the Frantz Fanon argued was commensurate with the concrete, practical struggle "to bring into existence the history of the nation - the history of decolonization" (p. 4).

\section{The Current Human Rights Crisis in the Philippines}

Since the time of Philippine President Ferdinand Marcos until the present administration of Benigno "Noynoy" Aquino, III, human rights violations have been a major problem in the Philippines. These human rights violations include, but are not limited to, enforced disappearances, extrajudicial killings, and abduction \& torture. These atrocities are in direct violation of the Universal Declaration of Human Rights, the Convention Against Torture, and the International Covenant of Civil and Political Rights.

The Universal Declaration of Human Rights (UDHR) was adopted by the United Nations on December 10, 1948. Stemming from the experience of World War II, this was the first global declaration of rights entitled to all human beings. Article 
3 of the UDHR states that "Everyone has the right to life, liberty and security of person." Article 5 states that "No one shall be subjected to torture or to cruel, inhuman or degrading treatment or punishment." And Article 9 states "No one shall be subjected to arbitrary arrest, detention or exile" ("Universal Declaration of,").

Similar to the UDHR, the Convention Against Torture is also a global expression in addressing torture worldwide. The Convention Against Torture defines torture as:

any act by which severe pain or suffering, whether physical or mental, is intentionally inflicted on a person for such purposes as obtaining from him or a third person information or a confession, punishing him for an act he or a third person has committed or is suspected of having committed, or intimidating or coercing him or a third person, or for any reason based on discrimination of any kind, when such pain or suffering is inflicted by or at the instigation of or with the consent or acquiescence of a public official or other person acting in an official capacity.

The Convention Against Torture also states in Article 2, "No exceptional circumstances whatsoever, whether a state of war or a threat or war, internal political instability or any other public emergency, may be invoked as a justification of torture" ("Convention against."). More recently, a scientific paper was published stating that torture is counterproductive. In Could the CIA Have Damaged Memories?, the paper states: "The methods could even have caused the suspects to create - and believe - false memories... The methods are actually counterproductive, no matter how much suspects might eventually say" (“Could CIA interrogation,” 2009).

International Covenant of Civil and Political Rights (ICCPR) is also a global commitment in upholding human rights, specifically civil and political rights of human beings. It was adopted on December 16, 1966, also by the United Nations. Article 6, Section 1, of the ICCPR states that "Every human being has the inherent right to life. This right shall be protected by law. No one shall be arbitrarily deprived of his life." Article 7 states that "No one shall be subjected to torture or to cruel, inhuman or 
degrading treatment or punishment. In particular, no one shall be subjected without his free consent to medical or scientific experimentation." And Article 9, Section 1, states that "Everyone has the right to liberty and security of person. No one shall be subjected to arbitrary arrest or detention. No one shall be deprived of his liberty except on such grounds and in accordance with such procedure as are established by law" ("International Covenant of,").

These global covenants and declarations, especially the particular articles just mentioned, should be paid attention to because the Philippines is one of the countries that signed and ratified all of these. Yet, human rights violations run rampant throughout the country, and those who are critical of the government are specifically targeted.

Human rights violations in the Philippines as they are recently occurring can be traced back to 1972, when President Ferdinand Marcos issued Proclamation 1081, declaring Martial Law and carried out what he called a "constitutional authoritarianism," "to save the republic," and "to reform society" ("Proclamation 1081 and,"). He did this out of fear of a growing opposition, namely a communist insurgency that numbered less than 500. Martial Law allowed Marcos to arrest thousands of his opponents as well as shut down schools, religious establishments, and print, radio and television media, actions which were supported by the U.S. Tadiar (2009) states that "Silent support from the U.S. government, which believed in the strengthening of state authority for the purpose of ensuring political stability for a sound business environment and the protection of foreign investments, served as international sanction for this state of affairs" (p. 188). The U.S. allowed all this to happen because of its interest and investments in the Philippines, which is rich in natural resources such as oil, gold, and lumber. Marcos 
welcomed U.S. and other foreign investment, but being corrupt and greedy as he was, the profit went into the coffers of his family and cronies, not for the development of the country.

With Martial Law in place, Marcos now had full control to dictate and police Filipinos as he pleased. Blaming the communists and other oppositional groups for the increased violence that was taking place across the nation, Marcos suspended the writ of habeas corpus and increased the armed forces to over 200,000 men. With full police powers at hand, the military was ordered to begin arresting and detaining students, workers, professionals, and anyone else that showed resistance and/or 'subversion' without warrants and/or probable cause. Human rights violations ran rampant during Marcos's dictatorship. In addition to extrajudicial killings, arbitrary arrests, and enforced disappearances, torture was used Marcos's military as an extreme exercise of power. Tadier (2009) illuminates this by citing Alfred McCoy's study of the Philippine military:

Torture became an instrument of state power in the Philippines only under Marcos's martial law regime, which 'used the spectacle of violence for civil control, becoming a theater state of terror.' Linking Philippine torture techniques to the methods of psychological torture and coercion researched and developed by the CIA and detailed in its thousand-page torture manual distributed to Latin American armies, McCoy shows the way torture was a play within the larger theater of terror of the Marcos regime, in which officers 'were actors who personified the violent capacities of the state' (p. 350-351).

Here we see the influence of the U.S. not only on economic matters in the Philippines, but also state-sponsored terrorism. Marcos justified these violations as means to improve "national security."

When Martial Law was proclaimed, one of the first politicians to be arrested by the military on order of Marcos was popular political leader Benigno S. "Ninoy" Aquino Jr. After being arrested, Aquino spent nearly 8 years in a military detention cell at Fort 
Bonifacio. In 1980, Marcos allowed Aquino to leave the country for an emergency heart bypass operation in the U.S. When Aquino decided to come home in 1983, the government tried to stop him, claiming that some people wanted to kill him. Nonetheless, Aquino persisted and was able to fly back to the Philippines using fake travel documents. When the airplane carrying Aquino landed at Manila International Airport on August 21, 1983, soldiers boarded the plane and took him away. As Aquino and his escorts were going down the airplane stairway, a shot was heard, followed later by more shots. Aquino was then found dead on the airport tarmac.

The assassination of Aquino was reported to have awakened Filipinos to the evils of Marcos as a dictator. Millions of Filipinos who sympathized with the slain leader and his family joined the funeral march to not only mourn, but to also express their feelings against Marcos. Aquino's death also consequently placed his widow, Corazon Aquino, in the forefront of the campaign to regain democracy in the Philippines. Thus, she became a candidate for presidency in 1986. The elections were marred by widespread fraud and terrorism committed by Marcos and his ruling party. The National Assembly proclaimed Marcos president, but Corazon Aquino led a nonviolent protest that had the support of millions of Filipinos, including the Catholic bishops. On February 22, 1986, Minister of Defense Juan Ponce Enrile and Vice Chief of Staff Fidel Ramos led a military rebellion against Marcos. Jamie Cardinal Sin appealed to the Filipino people to protect the two men. As thousands of civilians heeded the Cardinal's call, Enrile and Ramos declared that they believed Corazon Aquino was the true president. This started the People Power Uprising of 1986, which forced Marcos to flee the country. Francisco S. 
Tadad, a witness during the uprising, recalls in People Power: An Eyewitness Story (1986),

It was a revolution without precedent. Men, women, and children - armed with only crucifixes, images of the Blessed Virgin Mary, songs, and rosaries to signify their prayers - made themselves into human barricades. Made invulnerable by vulnerability, they faced up to armed Marines and Marcos forces. Corazon Aquino took her oath of office as president and Marcos fled into exile. People's power had regained democracy (p. 102).

Although the uprising placed Corazon Aquino as president and restored democracy to an extent in the Philippines, remnants of the Marcos regime, his cronies in government positions and a fascist military, remained in place and were a constant threat to the new democracy. This was mainly due to Aquino's efforts to engage in dialogue with the political Left and peace talks with the communist rebels, who membership grew to more than 16,000 by the time Marcos fled (President cory aquino's,"). This resulted in six failed military coups, as the military became a main power in the Philippines in dealing with the political Left, which would continue into the present administration of Gloria Macapagal Arroyo.

In a startling similar fashion, Martial Law in the Philippines manifested itself 30 years later in the form of President Gloria Macapagal Arroyo's (GMA) enactment of Proclamation 1017 in 2006. GMA carried out the State of Emergency for fear that "totalitarian forces of both the extreme Left and extreme Right" have intensified their "avowed aims to bring down the democratic Philippine State" ("2006 state of,"). This occurred after the government claimed that it foiled an alleged coup d'e'tat attempt against the President's administration earlier that same day. The Philippine government security also claimed that it had arrested a general who was involved in the coup attempt. 
The State of Emergency was lifted a week later with the announcement of Proclamation

1021. Below are the very words spoken by GMA to enact Proclamation 1017:

I, Gloria Macapagal-Arroyo, President of the Republic of the Philippines and the Commander-in-Chief of the Armed Forces of the Philippines, by virtue of the powers vested upon me by Section 18, Article 7 of the Philippine Constitution which states that: 'The President... whenever it becomes necessary... may call out (the) armed forces to prevent or suppress...rebellion...,' and in my capacity as their Commander-in-Chief, do hereby command the Armed Forces of the Philippines, to maintain law and order throughout the Philippines, prevent or suppress all forms of lawless violence as well as any act of insurrection or rebellion and to enforce obedience to all the laws and to all decrees, orders, and regulations promulgated by me personally or upon my direction; and as provided in Section 17, Article 12 of the Constitution do hereby declare a State of Emergency.

The State of Emergency temporarily suspended lower-level education classes and led to an immediate revocation on all licenses and permits to hold demonstrations and protests. The government also was given power to detain anyone indefinitely without the privilege of the writ of habeas corpus.

The Philippines under GMA was under de-facto Martial Law. Since coming into power in 2001 , her administration has been plagued by massive electoral fraud, corruption, militarism, surrender of national sovereignty, and pro-elite polices that violate the people's most basic social and economic rights. Basso (2007) states that the people's struggle for justice, peace and development, and national sovereignty and freedom has been met by fascist repression, a repression supported by the U.S. in its "war on terror" (p. 1). Her human rights violations record mirrors, if not exceeds that of Marcos. Cases of extrajudicial killings, torture, and enforced disappearances peaked reached 839 in 2007 (p.55), and the present number has exceeded 1,000. Witnesses point to the military in carrying out these atrocities, but because the corrupt government and military operate with sheer impunity, not one person has been tried or convicted. 
Philip Alston, United Nations Special Rapporteur on Extrajudicial Killings, conducted a report on the extrajudicial killings in the Philippines in 2007. In his 66-page report, he states:

The military is in a state of denial concerning the numerous extrajudicial executions in which its soldiers are implicated. Some military officers would concede that a few killings might have been perpetrated by rogue elements within the ranks, but they consistently and unequivocally reject the overwhelming evidence regarding the true extent of the problem. Instead, they relentlessly pushed on me the theory that large numbers of leftist activists are turning up dead because they were victims of internal purges within the CPP (Communist Party of the Philippines) and NPA (New People's Army). I repeatedly sought evidence from the Government to support this contention. But the evidence presented was strikingly unconvincing ("Report of the,").

Because of Alston's report, along with the efforts of Amnesty International, international concern from U.S. senators and world leaders, and aggressive campaigns of progressive Filipino activist organizations in the Philippines and U.S., the number of human rights violations has dropped significantly, peaking at 213 in 2006 and dropping to 63 in 2007 (Basso, p. 55).

In 2010, Benigno "Noynoy" Aquino, III, the son of democracy icons Ninoy Aquino and Corazon Aquino, became president of the Philippines. Much like U.S. President Barack Obama, Noynoy Aquino promised during his presidential campaign "hope and change" for the Philippines. He promised to prosecute his much-hated predecessor GMA and her cronies for graft and corruption as well as gross human rights violations. He was fashioned as the opposite of the evil GMA, being the son of two beloved Philippine democracy icons. However, "hope and change" began to appear as just lip service early into his administration and up until today.

The Noynoy Aquino government's mantra of change is now unraveling its true promise - that it is but a continuation of Gloria Macapagal-Arroyo's legacy of state terror, political repression and economic exploitation. Barely six months into 
Noynoy's presidency, there are already 28 victims of extrajudicial killings, making an average frequency of once a week. There are four victims of enforced disappearance, 19 victims of torture, 36 of arbitrary arrest and detention and almost 900 who were forced to evacuate their homes and croplands due to intense militarization (2010 Year-end report... pg. 1).

Despite being the son of two democracy icons and promising to go after the perpetrators of human rights violations in the Philippines, Noynoy's administration has done little to make good on his promises, and cases of human rights violations continue to rise. The counter-insurgency campaign of GMA was called Oplan Bantay Laya (Operation Freedom Watch) or OBL, modeled after U.S. military counter-insurgency programs. OBL was one of the bloodiest counter-insurgency campaigns in the history of the Philippines. Its main objective was to eradicate the communist rebellion by the end of GMA's term in 2010. However, since the definition of insurgent under the terms of OBL was very vague, hundreds of activists, progressives, and innocent civilians became victims. OBL ultimately failed, as the decades-old communist rebellion continued. However, under Noynoy's administration, the counter-insurgency campaign took on a new form as Oplan Bayanihan (Operation Cooperation) or OB. OB purported "peoplecentered" approach is nothing more than OBL with a new name.

Oplan Bayanihan is using a refurbished "triad operations" of (1) intelligence, (2) combat, and (3) so-called civil military operations. Even local government units and civil non-governmental organizations (NGO's) are being used under the pretext of a "whole nation" and "people centered" approach. It is nothing but "population control" and psychological operations (psy-ops) espoused by the new U.S. counter-insurgency guide (Sugar coated... pg. 34). 
Globalization, together with these counter insurgency programs, gross human rights violations, and massive poverty, has led to what is called a crisis of culture in the Philippines. Tardiar (2009) discusses this crisis in the context of the Filipina as “prostituted." Everything about her, her body, her people, her culture, her country, and her natural resources have been prostituted by colonial powers.

The figure of the prostitute has become the paradigmatic figure of the crisis of Philippine culture to the extent that the national economy drives its people to the same kind of living. As it was once put to me, "We are a nation of prostitutes." Taking the synecdochic part of the nation in crisis, the prostituted woman is the figure for the sacrifice of one's moral integrity, conceived as feminine sexuality, and the trammeling of one's sovereignty, conceived as masculine authority, losses which the culture, as a result of its state-keepers' betrayal, now suffers (p. 26).

Massive poverty as a result of neo-liberal policies that widen the economic gap between social classes have forced many Filipinas into prostitution out of sheer economic survival for their families and themselves. If not prostitution, then elsewhere in the Filipino diaspora as feminized labor. Currently, massive poverty in the Philippines due to globalization is one of the major factors in forcing over 4,500 Filipinos to leave the country daily for work abroad, and the overwhelming majority of those who leave the country are women ("Migrante"). As Strobel (2001) states,

Today the neocolonial status of the Philippines has produced poverty which pushes Filipino women to sell their pictures to mail-order catalogues; the yen, the deutschmark, and the dollar lure women to sing, dance, and carouse with foreign men in live hotels and night clubs; the pertodollars lure men to leave their families and make a living in the sweltering heat of the desert. All these because we need to build homes, literally and symbolically, in order to have a roof over our heads, to live decently and with integrity (p. 16).

This phenomenon known as the Overseas Filipino Workers (OFWs) has caused foreign employers to regard Filipinas in terms of feminized labor, such as housekeepers, nannies, domestic workers, caregivers, and nurses. Filipinas, and the Philippines as a whole, 
regarded as commodities and their labor feminized, are forced to serve the purpose of generating profit.

The feminization of labor is realized, therefore, from the same standpoint from which it is configured as masculine, that is, from the standpoint of capital. Hence, the prostitution of Filipinas is not merely the specific expression of the general prostitution of labor except from this standpoint. The prostitution of Pilipinas, the country, is realized as a metaphor for the prostitution of Filipinas, the woman, only through its totalization and abstraction from the particularities of Filipinas (Tadiar, p. 36).

Filipinas sacrifice not only their bodies and labor to be the breadwinners of their families, but they sacrifice their role as vessels of culture as well. Thus, the Philippine culture as a whole becomes lost, if not defined by this displacement from the home country, because it is given to foreigners.

As crucial elements of the cultural order, mothers, sisters, and daughters who take their reproductive caring elsewhere are seen as causing the disintegration of not only their families, but, by logical extension, of the values and indeed the moral fabric of Philippine society. In short, what is a crisis of cultural sovereignty within world nationalisms and internationalisms becomes, within a world of postnationalisms and cosmopolitanisms, a crisis of cultural dislocation, diffusion, and dysfunction. Throughout, "culture" is the "loss" of the nation, a loss embodied and effected by Filipinas and shaped by the forces of globalizing capital (Tadiar, p. 27-28).

In the process of serving the needs of colonialism, not only are Filipinas suffering,

but the nation as a whole suffers, suffers particularly from a loss of a cultural identity.

Tardiar echoes Constantino's sentiments of capturing the people's minds as the apex of successful colonization of their culture.

...Philippine culture was suffering under the weight of Western powers, duped by colonial mentality, weakened through brain drain, alienated and divided from itself, all to the economic and political detriment of the people. In Renato Constantino's version of this narrative, a version widely held in the wake of national political independence "granted" by the United States in 1946, true Philippine culture was itself oppressed, prevented from coming into authentic, unalienated, and empowered being: "Victims of cultural Westernization, we suffer a crisis of identity as well." (Tadiar, p. 27). 
The crisis of identity has deeply ingrained colonialism into the minds of Filipinas in terms of how they view themselves, especially physically. The fair-skinned caricature of Maria Clara during Spanish colonization symbolized power and prestige. This was further perpetuated during American colonialism and even up to today. The Filipina has come to make vast efforts to emulate the complexion and appearance of their colonizers, using them as the benchmarks of beauty, power and prestige. The rich and ruling class in the Philippines all tend to be fair-skinned many claim to be mestizo. This was exemplified by former First Lady Imelda Marcos during the regime of her husband Ferdinand Marcos, the U.S.-supported dictator of the Philippines from 1965-1986. In her mind she felt that her role as the First Lady was to be an example of beauty and prestige the Filipino people should aim to be, herself being a former beauty pageant queen. She has been quoted as saying, "I am a slave to the people. Therefore I must set the standard for beauty that the Filipino people should strive for." She regards herself as a true Filipina, but by that she means within the characteristics of Maria Clara. She is fairskinned, passive, came from a rich family, and led a lifestyle of extreme excess at the expense of the labor of the Filipino people, as exemplified by her 3,000 pairs of shoes. The lifestyle of her and her husband has significantly contributed to poverty in the Philippines, rendering Imelda Marcos' "standard of beauty" out of reach for the Filipino people.

In more recent times, media representation of Filipinas has set the standard for their self-image. Majority of the women celebrities are fair-skinned, and the mestiza look is always given preference. Furthermore, if the celebrity is truly of mestiza background, that is always celebrated. Media has gone to great lengths to presenting the ideal image of 
the Filipina in the celebrities they show, even enlisting the exclusive services of Dr. Vicky Belo, a dermatologist and cosmetic surgeon, whose validity of being a licensed surgeon has always been under speculation. In addition to providing cosmetic surgery, Belo is also the creator of Belo Essentials Skin Products, a line of skin whitening lotions and crèmes. Skin whitening and cosmetic surgery has become a billion dollar industry in Asia, and for Filipinas, destroyed their native culture and their bodies in place for white supremacy, skin cancer, and even death.

\section{Exploring the National Democratic Movement of the Philippines through Social Movement Theory}

\section{Social Movement Theory}

The theories on social movements that help guide this discussion come from the work of Donatella Della Porta \& Mario Diani (2006). In Social Movements: An Introduction, Della Porta and Diani state:

Social movements are a distinct social process, consisting of the mechanisms through which actors engaged in collective action:

- are involved in conflictual relations with clearly identified opponents;

- are linked by dense informal networks;

- share a distinct collective identity (p. 20)

Rather than being based on isolated actions, such as protests, social movements are longterm processes. The National Democratic Movement of the Philippines is such an example with the three mechanisms Della Porta and Diani described. The struggle over land is something the peasant class in the Philippines, which is about 70 percent of the population, have been fighting to take back from feudal landlords for centuries. The peasant and working class are two sectors the National Democratic Movement of the Philippines have been advocating for. The identified opponents are the feudal landlords, 
the government that funds and supports these landlords, and foreign corporations. Participants from the peasant farmers work with peasant-based organizations and networks in fighting to take back the land they till on which they believe is rightfully theirs, from as local as forming unions to as high up as working with progressive partylists and senators fighting hard to nationalize land for the Philippines and not foreign investors and corporations. Whether they are peasant, community organizer, or progressive party-lists and senators, they all share a collective identity as the National Democratic Movement of the Philippines.

Problems in the Philippines such as landlessness, human rights violations, sex trafficking, and worsening poverty have plagued the country for many years. It is because of these conditions that Filipinos are forced to migrate abroad for the survival of their finances and sheer livelihood. Yet despite these struggles, resistance to these problems has lasted just as long. As long as there are problems that violate basic human rights, there will be social movements of resistance. The reason the National Democratic Movement of the Philippines has lasted so long is because they believe the current system must and will change, if not for them, then for their children. This belief is validated by Della Porta and Diani's (2006) discussion on the belief in opportunities for change:

For protest to emerge, activists must believe that an opportunity exists, that they have the power to bring about change; and they must blame the system for the problem. Looking at structural opportunities without considering the cognitive processes which intervene between structure and action can be very misleading (Camson and Meyer 1996, Dim 1996). It is important, therefore, to analyze activists' understandings of available opportunities, the lenses through which they view potential opportunities for their movements (McAdam, McCarthy, and Zald 1996) (p. 18).

Like any other social movement, change does not come overnight, but only results from long-term processes. 
The National Democratic Movement of the Philippines is one that is very dynamic. It includes multiple sectors — peasant, indigenous, religious, youth \& students, educators, workers, migrants, women, and LGTBQ. Despite the myriad of sectors the organizations focus on, one unifying concept is human rights, which crosses all sectors. Della Porta and Diani (2006) also discuss the dynamics of social movements:

The initiatives against neoliberal globalization are very heterogeneous, and not necessarily connected to each other. They address a range of issues, from child labor's exploitation by global brands to deforestation, from human rights in developing countries to military interventions by Western powers. And they do so in a myriad of forms, from individual utterances of dissent and individual behavior to mass collective events, and from a variety of points of view. Looking at them well illustrates what doing "social movement analysis" actually means. (p. 2)

One needs to look no further than the cultural work of these organizations in the National Democratic Movement of the Philippines to analyze the movement itself. Their diverse cultural work reflects the diverse sectors they serve, what they go through, and how they are addressing their issues.

The National Democratic Movement of the Philippines is also a social movement that is transnational. Participants in the National Democratic Movement who are not in the Philippines do not see themselves in solidarity with the movement, but as active members with clearly defined roles and tasks. The assertion that cultural work in the National Democratic Movement of the Philippines is transnational stems from Filipinos in the diaspora having a very deep cultural sense of belonging to the Philippines, no matter where they are in the world. This deep cultural sense of belonging to the Philippines also extends to participants in the National Democratic Movement of the Philippines of Filipino descent who happen to have been born outside of the Philippines. This involvement of activists in the National Democratic Movement of the Philippines 
beyond national borders, active participants wherever they are in the diaspora, is what makes this social movement not just global, but transnational. This social movement is further elaborated on by Della Porta, Andretta, Mosca, \& Reiter (2006) in Globalization From Below: Transnational Activists and Protest Networks.

It follows, therefore, that a global movement should involve organizational networks active in different countries. In fact, social scientists have increasingly adopted the term "transnational" to emphasize the presence of supranational actors other than the national governments that are traditionally considered the only relevant subjects in international relations. Globalization has enhanced the power of some of these actors (such as transnational enterprises), but it has also fostered the emergence of a "global civil society" (p. 20).

Della Porta et al goes on to define global social movements, like the National Democratic Movement of the Philippines, in a transnational sense, borrowing from Sidney Tarrow's definition.

Accordingly, global social movements are supranational networks of actors that define their causes as global and organize protest campaigns that involve more than one state. In Sidney Tarrow's definition $(2001,11)$, transnational social movements are "socially mobilized groups with constituents in at least two states, engaged in sustained contentious interactions with power-holders in at least one state other than their own, or against an international institution, or a multinational economic actor" (p. 26).

In the National Democratic Movement of the Philippines, one of the main campaigns is against increased U.S. military intervention in the Philippines. This campaign is not just waged in the Philippines, but includes actions in other countries where there is a presence of Filipino activists in the movement, such as international chapters of Bagong Alyangsang Makabayan (BAYAN) in Hong Kong, Canada, and the U.S. BAYAN is a broad based alliance of people's organizations the Philippines, an alliance that is at the forefront of this social movement for national democracy and freedom, which will be discussed in later sections. The campaign against U.S. military intervention in the 
Philippines is one of many examples of a collective transnational mobilization involving supranational actors, whose actions includes protests, actions at Philippine consulates and embassies in different countries, and lobbying to government officials.

Collective transnational mobilizations in the National Democratic Movement of the Philippines translates into what Della Porta and Tarrow (2005) call "transnational collective action." In Transnational Protest \& Global Activism, they define this as coordinated international campaigns on the part of networks of activists against international actors, other states, or international institutions (p. 7). Transnational collective action as transnationalism in the National Democratic Movement of the Philippines will be discussed in later sections.

Transnational collective action can be easily translated into what Tarrow (2005) describes as "transnational activism," which he argues in The New Transnational Activism.

...individuals who move into transnational activism are both constrained and supported by domestic networks; that in making this move they activate transitional processes between states and international politics; and that when they return home, they bring with them new forms of action, new ways of framing domestic issues, and perhaps new identities that may some day fuse domestic with international contention (p. 2-3).

Tarrow describes how his father migrated from Poland (now Belarus) to the United States to escape poverty and social disorder during the 1920s. He would send remittance back to his family and community in his home country to help make it a better place to live, at times even going back himself. Tarrow described his father's transformation from remittances provider to diasporic nationalist as an example of transnational activism. The experience of Tarrow's father is a very similar story to the millions of Filipinos in the diaspora who still hold nationalist ties to their home country of the Philippines, remitting 
their earnings back to their families and communities in the Philippines. This example of transnational activism is what best describes the National Democratic Movement of the Philippines, in that beyond the billions of dollars in remittances Filipinos in the diaspora send back to the Philippines, activists in the National Democratic Movement living in the diaspora often return to the Philippines to integrate with the most marginalized populations to understand the root causes of the social problems in the Philippines and organize to advance the movement for national democracy in the Philippines. These integrations are what as known in the National Democratic Movement as Basic Mass Integrations, or BMR, which will be discussed in detail in later chapters. By being actively organizing to advance the movement, activists in the National Democratic Movement participate in the same transformation as Tarrow's father, redefining the term transnational from simply monetary transactions crossing international borders to being a patriotic duty to collectively and actively address social problems in the home country.

Tarrow describes this redefinition of the patriotic duty to one's home country from transactional to active, despite being in the diaspora, as transnational activism in three ways.

First, it shows how even prosaic activities, like immigrants bringing remittances home to their families, take on broader meanings when ordinary people cross transnational space... Second, even as they make transnational claims, these activists draw on the resources, networks, and opportunities of the societies they live in. Their most interesting characteristic is how they connect the local and the global...Finally, transnational activism is transformative: it may be turning thousands today from occasional participants in international protests into rooted cosmopolitans. That transformation could become the hinge between a world of states and one in which stateness is no more than one identity among many: local, national, and transnational (p. 2). 
Like the millions of Filipino migrants living in the diaspora, activists in the National Democratic Movement of the Philippines who are also living outside of the Philippines still consider themselves citizens of the Philippines nation, as they identify with stateness as not just living in the Philippines, but that collective identity of stateness is taken with them wherever they are in the world. They are active participants in the National Democratic Movement of the Philippines wherever they happen to be in the world because they believe it is their patriotic duty as citizens to build a Philippine society of national democracy, a home country they can return to that is eradicated of the social problems that forced them to migrate in the first place.

Cultural workers, like all activists in the National Democratic Movement of the Philippines, seek to create a culture and society that is reflective of themselves, not a culture defined by the grand narrative of dominant systems of power and oppression, as seen throughout the history of colonization. They seek to create a culture and society that is reflective of their social conditions. This is what Della Porta et al (2006) defined a fundamental characteristic for all social movements.

The fundamental characteristic of a social movement is its ability to develop a common interpretation of reality to nurture solidarity and collective identifications. The movements develop new visions of the world and systems of values alternative to the dominant ones (p. 18-19).

In all social movements, there is an inherent learning that takes place for activists and the marginalized communities they are integrated with. It is in the midsts of struggle and resistance against oppression that learning about the social problems marginalized communities face where they learn to identify their struggles and opponents, and more importantly learn to address injustices. Much like Boal's (1974) pedagogy of the oppressed, this learning in the midsts of struggle is what Aziz Choudry (2007) discusses 
as "pedagogy of mobilization" in Transnational Activist Coalition Politics and the

De/Colonization of Pedagogies of Mobilization: Learning from Anti-Neoliberal

Indigenous Movement Articulations.

Holst (2002) used the term "pedagogy of mobilization" to describe "the learning inherent in the building and maintaining of a social movement and its organizations"(p. 87). Mobilization against neoliberal policies and practices provides a potential pedagogical tool to bring to the fore struggles and strategies around decolonization, and to build an analysis of contemporary social, environmental, economic, and political issues grounded in an understanding of colonialism, not as a historical occurrence, but as an ongoing process. Such a pedagogy of mobilization can potentially broaden understanding and debates among non-Indigenous communities by making explicit links and connections between older forms of colonialism and apparently newer forms of economic, environmental, social, and political injustices that both Indigenous and nonIndigenous communities face...Learning about links between injustices alone is insufficient to bring about change: people also need an organizing or collective context in which to act (p. 100).

The National Democratic Movement of the Philippines is an example of pedagogy of mobilization, as cultural workers and organizers in the movement become the organic intellectuals and popular educators of the communities they integrate with. This learning in turn breeds leaders and organizers who come from these communities, which is part of the ongoing process of further building and expanding the movement. This learning in marginalized communities through cultural work in the National Democratic Movement of the Philippines, and the subsequent collective action of marginalized communities to address injustice and oppression will be further elaborated on in later chapters.

Learning in the midsts of struggle, and in turn the knowledge produced by marginalized communities, is further elaborated in Choudry's (2009) Learning in Social Action: Knowledge production in social movements. Choudry contends that social practice, such as cultural workers in the National Democratic Movement of the 
Philippines organizing with marginalized communities, can inform how these

communities who lack access to formal education can become educated.

Yet it is my contention that for all educators - whether in formal settings such as school classrooms and university seminars, or in non-formal... or informal settings...the dynamic body of knowledge and pedagogical tools arising from a activist practice offer important practical insights which can inform teaching practice and our understandings of knowledge production and learning processes (p. 6).

Unlike formal education and learning, such as schools and universities, Choudry asserts that knowledge is produced through community engagement. Rather than knowledge being dropped on marginalized communities by those with the privilege of formal education, marginalized communities would have the best knowledge to speak on oppression because they are the ones experiencing struggle firsthand.

[In] Griff Foley's (1999) Learning in Social Action...Foley emphasizes the importance of "developing an understanding of learning in popular struggle" (p. 140). His attention to documenting, making explicit, and valuing incidental forms of learning and knowledge production in social action is consistent with others who understand that critical consciousness, rigorous research and theory can and do emerge from engagement in action and organizing contexts, rather than as ideas developed elsewhere being dropped down on "the people" from movement elites (L.T. Smith, 1999; Kelly, 2002; Bevington \& Dixon, 2005; Kinsman, 2006). (p. 6).

Resonating with the previously discussed “pedagogy of mobilization” and Boal's (1974) pedagogy of the oppressed, cultural workers closely integrated with marginalized communities is what has allowed marginalized communities to produce knowledge of the struggles they face, informing the cultural work they produce, and thus building and expanding the National Democratic Movement. How cultural work and cultural workers closely integrated with marginalized communities builds this social movement will be discussed in detail in Chapter 4. 
History of the National Democratic Movement of the Philippines

As discussed in previous sections, the National Democratic Movement of the Philippines can be traced back to the Katipunan and the Philippine Revolution of 1896, a revolution that many activists believe continues to this day. U.S. imperialism in the Philippines has frustrated the realization of national democracy, thus the struggle for it continues through the National Democratic Movement. Sison (1995) articulated the urgency for the resumption and completion of the unfinished revolution by today's generation of Filipino youth in his work The Struggle for National Democracy.

There is only one nationalism that we appreciate. It is that which refers to the national democratic revolution, the Philippine revolution, whose main tasks now are the liquidation of imperialism and feudalism to achieve full national freedom and democratic reforms... With the continuing triumph of U.S. imperialism in the Philippines and the stability of its control, it is the chief task of the Filipino youth to resume and complete the unfinished revolution under the banner of national democracy, to expose and oppose the national and social iniquities caused by U.S. imperialism and its local reactionary allies (pp. 9-10).

This social movement for nationalism has been marked by events of anti-imperialism. E.

San Juan discusses this history in his essay The National Democratic Struggle in the

\section{Philippines.}

The central founding "event" (as the philosopher Alain Badiou would define the term) is the 1896 revolution against Spain and its sequel, the Filipino-American war of 1899-1902, and the Moro resistance up to 1914 against U.S. colonization. Another political sequence of events is the Sakdal uprising in the thirties during the Commonwealth period followed by the Huk uprising in the forties and fifties - a sequence that is renewed in the First Quarter Storm of 1970 against the neocolonial state (San Juan, National...).

The Moro resistance refers to the resistance by the Moro people of Mindanao, the southern region of the Philippines that is predominantly Muslim. The Commonwealth period was the time when the Philippines was a commonwealth of the United States, and Filipinos were not U.S. citizens, but considered "U.S. Nationals." The Huk uprising 
during World War II and the 1950's was the armed struggle led by the Hukbalahap

(Hukbong Bayan Laban sa mga Hapon, in English: The Nation's Army Against the Japanese) against Japanese occupation of the Philippines and later on against U.S. imperialism. The First Quarter Storm was a series of large-scale protests against the graft and corruption of President Marcos' government, led by the radical youth and student organization Kabataang Makabayan (Patriotic Youth).

The National Democratic Movement of the Philippines identifies the hegemony of U.S. imperialism as the main opponent of national democracy. It takes after other nationalist movements in the third world who have also been affected by imperialism in the form of globalization, and continues its anti-imperialist stand and aspirations for national democracy to this day drawing from the lessons learned from past defeats.

The Filipino culture of nationalism constantly renews its anti-imperialist vocation by mobilizing new forces (women and church people in the sixties, and the indigenous or ethnic minorities in the seventies and eighties). It is organically embedded in emancipatory social and political movements whose origin evokes in part the Enlightenment narrative of sovereignty as mediated by third-world nationalist movements (Ghandi, Ho Chi Minh, Mao) but whose sites of actualization are the local events of mass insurgency against continued U.S. hegemony. The Philippines as an "imagined" and actually experienced ensemble of communities, or multiplicities in motion, remains in the process of being constructed primarily through modes of political and social resistance against [globalization] and its technologically mediated ideologies, fashioning thereby the appropriate cultural forms of dissent, resistance, and subversion worthy of its people's history and its collective vision (San Juan, National...).

As San Juan discussed, the culture of nationalism in this movement takes on cultural forms of resistance. This furthers the assertion that cultural work is at the forefront of the National Democratic Movement of the Philippines.

In doing research on the National Democratic Movement of the Philippines in the Philippines as it is now, it is unfortunate that there is little to no literature or research. 
When one does an internet search, what usually comes up is the National Democratic Front of the Philippines (NDFP). The NDFP is a united front of organizations in the Philippines advocating for revolutionary armed struggle, whereas the National Democratic Movement of the Philippines is a more broad based movement of people's organizations working for social change through mass, legal, and parliamentary struggles. At present, when discussing the history of the National Democratic Movement of the Philippines, one can go to the members of BAYAN, a broad based alliance in the National Democratic Movement of the Philippines which is at the forefront of the growing social movement for democracy and freedom.

In the mid-1960s, a new type of National Democratic Movement in the Philippines began to take form, founded on a clear nationalist and anti-imperialist line. It gained national prominence during the First Quarter Storm of 1970 and took deep root among the people. The declaration of martial law in 1972 by President Ferdinand Marcos failed to thwart the growth of this movement. The peasant movement for genuine agrarian reform rapidly gained ground, as well as the workers' strike movement. Students, teachers, professionals and the religious took to the streets to defend civil liberties and the people's democratic rights (bayanusa.org).

The assassination of opposition leader Benigno "Ninoy" Aquino in 1983 sparked larger protests against the Marcos dictatorship. At the core was the National Democratic Movement of the Philippines, leading such broad alliances as the Justice for Aquino Justice for All Movement (JAJA); Nationalist Alliance for Justice, Freedom and Democracy (NAJFD); and the Coalition of Organizations for the Realization of Democracy (CORD). The Bagong Alyansang Makabayan (New Patriotic Alliance), or 
BAYAN for short, was formed in May 1985, bringing together more than a thousand community organizations composed of more than a million members. Represented were different classes and sectors committed to the people's struggle for national freedom and democracy (bayanusa.org).

Staunch nationalist Sen. Lorenzo Tañada, was elected as the founding chairperson. BAYAN soon became the coordinating focal point for open large-scale mobilizations against the brutal and hated dictatorship. It led large demonstrations and people's strikes in Metro Manila and the country's major urban areas, contributing greatly to the eventual downfall of the U.S.-backed Marcos regime. But the end of the Marcos regime was not enough to ensure the fulfillment of the people's just demands. Succeeding regimes further entrenched foreign domination and elite rule. However, the National Democratic Movement of the Philippines continued the same mass mobilizing work during the administration after Marcos (bayanusa.org).

Throughout this time, tens of thousands of Filipinos and allies throughout the U.S. have contributed to the cause of national democracy in the Philippines. After the declaration of martial law in 1972, thousands of Filipino compatriots who migrated to the U.S. worked to end the Marcos dictatorship until its demise and toppling in 1986. They were supported by allies of diverse ethnic, racial, national, class and sectoral backgrounds in the U.S. Since the founding of BAYAN-Philippines, thousands of individuals and organizations in the U.S., both Filipino compatriots and multi-racial allies, have answered the calls of BAYAN-Philippines.

BAYAN-USA was formally established in 2005 , serving as a direct connection to the National Democratic Movement of the Philippines and BAYAN-Philippines, 
comprising of 15 progressive Filipino American organizations located throughout the U.S. Recent activities include conducting aggressive campaigns to stop human rights violations in the Philippines and junking the Visiting Forces Agreement, which is a unilateral agreement between the U.S. and the Philippines to use the Philippines for "military exercises" for an unspecified length of time. This agreement cost U.S. taxpayers millions of dollars per year since 1999 (bayanusa.org).

\section{History of Filipino Migration and Transnationalism}

Filipinos have been migrating to the U.S. since 1587, a migration history called

"The Seven Waves and Eras of Filipino American History" (Tintiangco-Cubales et al, p.

227). My family migrated during the sixth wave, the era of "Post-1965 Immigrants; AntiMartial Law Movement” (Tintiangco-Cubales et al, p. 229).

Thousands of Filipinas/os poured into the U.S. from 1965-1986, many of them entering under specific preferences that favored educated professionals, triggering a "brain drain" in the Philippines (Tintiangco-Cubales et al, 2007).

Many who left the Philippines for work abroad during the late 1960s to 1980s were college educated and earned professional degrees. During the Marcos dictatorship, the Philippines amassed huge foreign debt, and in order to alleviate the foreign debt, Marcos implemented the Labor Export Program that would send Filipino workers overseas for jobs and remit their earnings back to the Philippines. This new commitment to an exportoriented economy transformed the relationship between labor and nation building in the Philippines (Choy, 2003).

[In 1974] the Marcos regime in the Philippines enacted the Labor Export program (LEP) to consolidate its systemic export of Filipino workers and professionals as commodities to work in other countries and use their remittances to finance the underdeveloped economy (Chua, 2009). 
The LEP was only meant to be temporary, but seeing how remittances raked in billions of dollars annually, this program is still in existence to this very day. To this day, my family here in the U.S., myself included, as unofficial Overseas Filipino Workers (OFWs) sends money back to our relatives in the Philippines, who belong to the urban poor or peasants. Like many Filipinos living in the U.S., if we can't afford to visit or go back to the Philippines, we remit our earnings to our loved ones through remittance agencies in the U.S. These agencies advertise remittance services as maintaining closeness with family in the Philippines as well as promoting national loyalty, which is a problematic reinforcement of an economic policy that has resorted to remittances by OFWs rather than create jobs in the Philippines.

In 1994, BPI Express tapped another sentiment — national loyalty: "YOUR REMITTANCE DOLLAR SUPPORTS MORE THAN JUST YOUR FAMILY. IT SUPPORTS A NATION. EVERY DOLLAR YOU SEND HOME BUYS MORE THAN WHAT YOUR LOVED ONE NEED. YOUR REMITTANCE DOLLAR HELPS PAY FOR ESSENTIAL IMPORTS VITAL TO THE PHILIPPINE ECONOMY (Posadas, 1999, p. 141).

Despite the Philippine government hailing OFWs as the "Bagong Bayani" (New Heroes) of the country, it has done almost nothing to ensure their rights and welfare are protected while working abroad. Their "heroic" bodies are regarded as subsidized commodities that stimulate the economy.

As a receptive, pliable, permeable body, investment in which yields value, the [Filipino] seems to be the private stimulation of the Philippines...except that in the subcontracting of their bodies they both share the same military and corporate clients and produce the same surplus values: political power and capital, values that only exceed the grasp of their producers but moreover return as even greater forces for their exploitation (Tardiar, 2009, p. 29).

Currently, the history of Filipino migration in the seventh wave, called the era of

Filipinos in the Diaspora. This current era is marked by globalization policies that force 
4,500 Filipinos to leave the country daily in search for work ("Migrante"). Large communities of overseas Filipinos are found throughout the world, numbering in the thousands, extending the Philippine nation beyond its borders.

In the context of globalized capitalism today, the Filipino diaspora acquires a distinctive physiognomy ad temper. It is a fusion of exile and migration: the scattering of a people, not yet a fully matured nation, to the ends of the earth, across the planet throughout the sixties and seventies, continuing up to the present. We are now a quasi-wandering people, pilgrims or prospectors staking our lives and futures all over the world - in the Middle East Africa, Europe, North and South America, Australia and all of Asia; in every nook and cranny of this seemingly godforsaken earth (San Juan, 1998, p.190).

Conditions in the Philippines such as landlessness, poverty, and unemployment have created this migration phenomenon of Filipinos being found in virtually every part of the world. In order to alleviate the fractured economy, the Philippine government exports its most valuable natural resource, which is not gold, oil, nor minerals, but Filipino labor. This has created what Rodriguez (2010) calls the Philippines as a labor brokerage state, in her work Migrants for Export: How the Philippine State Brokers

\section{Labor to the World.}

Labor brokerage is a neoliberal strategy that is comprised of institutional and discursive practices through which the Philippine state mobilizes its citizens and sends them abroad to work for employers throughout the world while generating "profit" from the remittances that migrants send back to their families and loved ones remaining in the Philippines (p. x).

Rodriguez takes this further by quoting Antonio Tujan of IBON (a nonprofit researcheducation-information- development institution) as the Philippine state engages in nothing more than "legal human trafficking" (p. x). Because of the Philippine government sending Filipinos to leave the Philippines everyday by the thousands to work abroad, it has redefined for its own purposes the very meaning of citizenship, that is 
leaving the Philippine to work abroad as a civic duty accomplishes Philippine nationalism (p. xxvi).

As previously discussed, the LEP was established by President Marcos not only to alleviate national debt, but to quell resistance that was growing under his dictatorship.

Migrants' remittances helped to strengthen the country's foreign exchange reserves and thereby help the government to maintain its debt repayments. Marcos violently suppressed the growing communist movement, which was at the forefront of the struggle to depose his dictatorship. He saw the export of labor as an important measure to curb the political unrest likely to be exacerbated by unand underemployment (p. 12).

In this effort to silence opposition to his dictatorship, Marcos also made efforts to raise the status of the balikbayan (nation returnee) as a national honor. Prior to his so called balikbayan program, which encourage migrants to return to the Philippines ultimately as investors, migrants were referred to as part of the nation's "brain drain," as some form of national disloyalty. Even though Marcos changed the meaning of the Filipino migrants' civil duty and raising their status to a high regard, his government were suppressing the rights of the citizens living in the country (p. 81).

These problems in the country under the Marcos dictatorship, and subsequent governments, created ripe conditions for the Filipino people, both in the Philippines and abroad, to join in the national democratic struggle. The catalyst for the Filipino migrant struggle becoming part of the National Democratic Movement of the Philippines was the execution of Filipina domestic worker Flor Contemplacion in 1995 at the hands of the Singaporean government for allegedly murdering a fellow Filipina domestic worker. Many believed that Contemplacion was falsely accused by her employer, possibly to take the fall for the murder. Thousands of Filipinos in the Philippines and abroad rallied in her support and called on the Philippine government to intervene. Unfortunately, the 
Philippine government did nothing to stop her execution. Contemplacion's case exemplified the vulnerabilities and abuses Filipino migrant workers face abroad, at the hands of both their employers in host countries as well as the Philippines government (p. 93). "The highly publicized and transnational nature of the Contemplacion protests produced a political crisis, one that was critically centered, for the Philippine state" (p. 93).

It was the case of Flor Contemplacion that made Filipino migrants and their families in the Philippines realize that the protection of their rights and welfare will not come from the Philippine government nor the host countries, but it will have to come from their own organizing efforts to pressure the government. The mobilizations worldwide by Filipino migrants for Flor Contemplacion exemplify Della Porta \& Diani’s (2006) "social movements as a distinct collective action," and more sharply, Della Porta \& Tarrow's (2005) “transnational collective action.”

Filipino migrants' transnational political mobilizations on behalf of Angelo de la Cruz, Flor Contemplacion, and others since then illustrate how engagement with the Philippine state has become a vital means by which Philippine migrants have come to assert their rights both in their countries of employment as well as in the Philippines. It was Migrante International's grassroots transnational mobilizations in the wake of the Flor Contemplacion hanging that were instrumental in compelling the Philippine state to introduce RA8042 [which extends protections to migrants while they work abroad], which in turn led to significant reforms in Philippine migration policy (p. 149).

Migrante International is a worldwide organization of Filipino migrants that seek to defend and protect the rights and welfare of Filipino migrants abroad and their families in the Philippines.

This transnational movement has also redefined the meaning of citizenship, coming from the citizens themselves and not the government. Zinn (2003) stated, "to 
criticize the government is the highest act of patriotism" (p. 4). For Filipino transnational activists and cultural workers, they have accomplished this in their work in the National Democratic Movement of the Philippines, which has extended beyond the Philippines, while asserting their nationalism to the Philippines.

This citizenship is not conferred by states or international institutions. In other words, it is not "top down"; rather the assertions of transnational citizenship have come from the "bottom up." Moreover, Philippine migrants have built a transnational movement that originates in the homeland and extends to the diaspora (p. 150).

For organizations like Migrante, and in this case transnational cultural workers in the National Democratic Movement, to be politically engaged in asserting their nationalism to the Philippines is an act of presenting a counter-narrative to the grand narrative of what citizenship and patriotism should be. This is what Rodriguez calls as "counter-hegemonic (trans)nationalism" (p. 152).

Migrante's transnational political mobilizations can therefore be also described as counter-hegemonic (trans)nationalism. It is "counter-hegemonic" in that Migrante's linkages to the homeland are not with traditional political parties or other state institutions, as scholars have found in case studies of other forms of migrant transnationalism, but instead with radical social movements. It is (trans)national because, while Migrante is engaged in transnational political action around migrants' rights, it is less invested in migrants' political incorporation in their host societies than in social transformation in the homeland. Because it links migration to broader processes of neo liberal globalization, Migrante has become active in the progressive and militant nationalist movement of the Philippines (p. 152).

In the practice of counter hegemonic transnationalism, Migrante sees its role in building a global migrant workers' movement that is linked to the broader National Democratic Movement of the Philippines that carries on the work towards realizing its goal of a national democratic Philippines, as originally aspired by the unfinished Philippine Revolution of 1896. 


\section{CHAPTER III}

\section{METHODOLOGY}

\section{Background of the Researcher}

Cultural work to me has meant using my art to highlight the beautiful struggle of the oppressed against the injustices of society, as well as a tool of organizing marginalized communities towards social action. This has been inspired by several events in my life as a cultural worker for the National Democratic Movement, which started with my first basic mass integration in the Philippines in the summer of 2006, though I have been familiar with the movement since 2003. Since then, I have used my background in Hiphop dance to choreograph dance performances with themes of struggle and resistance, as well as using my talents in video and music production to produce short documentaries that highlight the struggles and beauty of our movement.

One of the major highlights in my life as a cultural worker was sharing my talents in Hiphop dance and teaching it to urban poor youth in the Philippines, during my second basic mass integration in 2010. I was able to work and organize with families and youth of OFW's, with students, and with cultural workers. We performed a Hiphop dance piece that expressed resistance to human rights violations at the People's SONA, in front of tens of thousands of people. The People's SONA is spearheaded by the National Democratic Movement. The cultural work I was able to create in the Philippines with my fellow cultural workers in the midst of rampant human rights violations further deepened my commitment to the National Democratic Movement of the Philippines.

Another highlight was choreographing a flash mob dance with the theme of antiimperialism, which we performed as part of the large-scale demonstration attended by 
tens of thousands of activists from all over the world, against the NATO and G8 summit in Chicago, IL, in 2012. We were part of a contingent led by the International League of People's Struggle (ILPS), an international anti-imperialist people's organization whose membership includes national democratic mass organizations. Amateur videos of the flash mob were immediately posted all over social media. Although he was not able to be physically present in Chicago for the ILPS and anti-NATO/G8 activities due to his designation by the U.S. as a "person supporting terrorism," Jose Maria Sison, the Chair of ILPS and the chief political consultant of the National Democratic Front of the Philippines, saw videos of the flash mob and proudly reposted it on his Facebook page with the caption, "The ILPS can dance!"

More recently, I have used my talents in video production to help produce educational materials on various social issues, along with a loose collective of other cultural workers. These social issues include the misuse of public funds by corrupt politicians in the Philippines, im/migrant struggles, and environmental justice.

In regards to environmental justice, I along with my fellow cultural workers produced educational materials in the aftermath of Typhoon Haiyan in November 2013. This super typhoon is the strongest typhoon in recorded history, whose path of destruction in the Central Visayas region of the Philippines left thousands of people dead, millions more displaced, and millions of homes and property destroyed. These education materials we produced, along with coordinating the National Alliance for Filipino Concerns (NAFCON)'s Bayanihan Disaster Relief campaign, were critical in garnering international support for the survivors of the typhoon. We were able to highlight the typhoon's massive devastation, along with the devastation of the corrupt Philippine 
government's criminal negligence and ineptitude in responding to the disaster. To date, we were able to raise over $\$ 800,000$ for relief and rehabilitation operations, which we wire directly (without government intervention) to our partner organization in the Philippines, BALSA (Bayanihan Alay sa Sambayanan, or "Community Offering to the People"). BALSA is a nation-wide disaster relief operation network in the Philippines that is part of the National Democratic Movement. This campaign even garnered the support of mainstream U.S.-based celebrities; such as Hiphop artists Macklemore, Raekwon, ?uestlove, and Kaskade; Hiphop mogul Russell Simmons; Pulitzer-prize winning journalist and immigrant rights activist Jose Antonio Vargas; and actor Dante Basco.

To discuss this topic of cultural work in the National Democratic Movement of the Philippines is special to me not only because it is part of my daily work as a Filipino American cultural worker, but because I have personal connections to victims of human rights violations in the Philippines and abroad. In 2006, I was part of a BAYAN-USA member organization called League of Filipino Students-SFSU (LFS), which is the U.S.based chapter of LFS in the Philippines. I was in the Philippines that summer integrating with the youth, student, indigenous, and urban poor sectors there, and one day I was to meet with LFS members at University of the Philippines, Diliman, in Quezon City. I found out that day that two of their members, Sherlyn Cadapan and Karen Empeno, were abducted by the military two days prior. It was a heavy and emotional way to meet with LFS members in the Philippines for the first time. The year prior, one of their leaders, Chris Hugo, was assassinated. These LFS members were basically doing the same work I was with LFS at SFSU, such as fighting tuition hikes and the denial of tenure of a 
brilliant professor. These human rights violations made me realize the privilege I have as U.S. citizen with the right to free speech without fear of abduction or execution.

My dear friend, Melissa Roxas, a U.S. citizen of Filipina descent, who was in the Philippines doing volunteer medical work in the countryside in May of 2009, was abducted and tortured for five days by the military. She is one of the fortunate few to have resurfaced from abduction. Since her ordeal, she courageously filed for writ of amparo and filed a lawsuit against the Philippine military. She still continues her work as a cultural worker.

An incident of human rights violations even happened in my own family. Before I was born, my grandmother's brother was an activist in the Philippines during the Marcos dictatorship. I was told that things got so bad he had to go underground, leaving the family for their safety. He was eventually killed during a skirmish with the military. This event in my family's life is the reason why they are always very worried about me, because of my activism. It has resulted in many arguments, but I do it because I know how important the work is. Knowing that the cultural work I do is highlighting the struggles and beauty of our movement and providing the narratives of marginalized communities not represented in mainstream discourse are what keep me grounded. It is my purpose and responsibility as a cultural worker to my people, and to all victims of human rights violations worldwide.

\section{Restatement of the Purpose of the Study}

The purpose of this study is to examine the extent to which cultural work brings political consciousness to marginalized populations who do not have access to education. Another objective is to examine the impact of cultural work locally and transnationally as 
a tool for social change and for addressing issues that impact marginalized populations, particularly in the National Democratic Movement of the Philippines. This movement is a social movement that goes beyond the borders of the Philippines.

As the final lines of Lino Brocka's poem Artist as Citizen closely defines what it means to be a cultural worker, "The artist is a committed person, that he will always take the side of any human being who is violated, abused, oppressed, dehumanized whatever his instrument- the pen, the brush, or the camera." Cultural workers are deliberate in creating culture as an act of resistance to imperialist culture, and much of the stories they tell though their creative work are outside mainstream media. Cultural work also deconstructs the myth of artists working in isolation from the community. Cultural workers are not just artists, but more importantly are community organizers working closely with the community, and in many ways are "popular educators" and "organic intellectuals," which I will discuss in later chapters.

\section{Overview}

Cultural work being central to social movements, not as peripheral, is what guides the development of the research questions that inspire this inquiry: 1) According to cultural workers, what is cultural work and how does it look in a transnational context? 2) How is cultural work used in the National Democratic Movement of the Philippines? 3) What are the implications of cultural work for marginalized communities in the Philippines and the United States?

This chapter will focus on the qualitative research methodology used for this study. According to Creswell (2008), qualitative research is

a type of educational research in which the researcher relies on the views of participants, asks broad, general questions; collects data consisting largely of 
words (or texts) from participants; describes and analyzes these words for themes; and conducts the inquiry in a subjective, biased manner (p. 46).

The qualitative method used for this study is narrative research, particularly oral history. Cultural work is used to give voice to the oppressed, marginalized, and voiceless.

Narrative research, used in this context, compliments the quest for voice and representation of the marginalized in mainstream inquiry and discourse.

Connecting personal narratives and lived experiences to producing cultural work in a transnational social movement that combats imperialism and the human rights violations it manifests, was also an equally important lens used to develop the research questions of this study. With the Philippines as a former colony of Spain and the United States, and some would argue it continues to operate as a neo-colony of the United States, Filipinos have a long history of struggling with imperialism. As discussed in the section on Miseducation and Decolonization in the Philippines in Chapter II, centuries of colonization have rendered the Filipino people without a narrative written by themselves, and have been subjugated to the grand narrative ingrained into their being. Though this study is a research on a people fighting to escape the grips of imperialism, I struggle with using the term "research" for this study, as it is a very Western term. Many difficulties with this term come to mind when using it to study a people still dealing with the trauma, both literally and figuratively, of the effects of colonialism and imperialism. As Smith (1999) states,

From the vantage point of the colonized, a position from which I write, and choose to privilege, the term 'research' is inextricably linked to European imperialism and colonialism... When mentioned in many indigenous contexts, it stirs up silence, it conjures up bad memories, it raises a smile that is knowing and distrustful...the ways in which scientific research is implicated in the worst excesses of colonialism remains a powerful remembered history for many of the world's colonized peoples (p. 1). 
As discussed in Chapter II, Filipinos have suffered through historical trauma and cultural amnesia at the hands of centuries of colonization. The killing of indigenous bodies was not enough for the Spanish and American imperialists. To fully subjugate the remaining bodies, it was necessary for the imperialists to capture the hearts and minds of the conquered. This was accomplished by education systems that ingrained into their minds a history and culture, a narrative, as authored by the imperialists. However, as also discussed in Chapter II, Filipinos have a long history of resistance to colonization and imperialism, as history and narrative that cultural workers in the National Democratic movement have been telling, and continue to tell, through their various mediums of cultural work, beginning with the First Propaganda Movement prior to the Philippine Revolution of 1896 , the seditious plays at the turn of the $20^{\text {th }}$ century, to the Second Propaganda Movement of 1960 up to today, all of which is discussed in Chapter II. They have their own stories to tell, stories that are often neglected and ignored in the grand narrative. And when particular histories of Filipinos happen to be included in the grand narrative, it is often told by researchers who have little knowledge of the Philippines and Filipinos. Smith (1999) also states,

It galls us that Western researchers and intellectuals can assume to know all that it is possible to know of us, on the basis of their brief encounters with some of us. It appalls us that the West can desire, extract and claim ownership of our ways of knowing, our imagery, the things we create and produce, and then simultaneously reject the people who created and developed those ideas and seek to deny them further opportunities to be creators of their own culture and own nations. It angers us when practices linked to the last century, and the centuries before that, are still employed to deny the validity of indigenous peoples' claim to existence, to land and territories, to the right of self-determination, to the survival of our languages and forms of cultural knowledge, to our natural resources and systems of living within our environments (p. 1). 
The people of the Philippines, particularly cultural workers in the National Democratic Movement, reject this notion of the grand narrative and actively provide the counter narrative. I would take this further by stating that cultural workers in the National Democratic Movement of the Philippines provide the resistance narrative, which Smith further illustrates,

Indigenous peoples across the world have other stories to tell which not only question the assumed nature of those ideals and the practices that they generate, but also serve to tell an alternative story: the history of Western research through the eyes of the colonized. These counter stories are powerful stories of resistance which are repeated and charred across diverse indigenous communities (p. 2).

By using narrative research as the methodology, this study deconstructs imperialism, as told by the people themselves. Much like the cultural work that is produced by the cultural workers referred to in this study, using narrative research through the stories of cultural workers is a process of decolonization, which Smith also highlights,

In a decolonizing framework, deconstruction is part of a much larger intent. Taking apart the story, revealing underlying texts, and giving voice to things that are often known intuitively does not help people to improve their current conditions. It provides words, perhaps, an insight that explains certain experiences_-but it does not prevent someone from dying (p. 3-4).

This chapter will discuss the following research methodologies: (a) the research design; (b) the research setting; (c) the population and sample; (d) validity and reliability; (e) data collection; (f) the procedures used for data analysis; and (g) ethical considerations.

\section{Research Design}

Narrative research methods were utilized to gather the narratives of Filipino cultural workers and organizations both in the Philippines and the United States. These cultural workers are part of the National Democratic Movement of the Philippines. This narrative approach consisted of creating dialogue between the participants and myself. I 
took on the role of an active participant observer for two purposes: to observe the activities, people, and physical aspects of situations; and to engage in activities that are appropriate to a given situation and that provide useful information (Wolcott, 1988, p. 191).

By identifying the participants and allowing them to share their narratives, they were able to articulate their own histories and experiences. According to Creswell (2008), the researcher "relies on the views of participants; asks broad, general questions, collects data consisting largely of words (or text) from participants; describes and analyzes these words for themes; and conducts the inquiry in a subjective, biased manner" (p. 46). Narrative research also "focuses on studying a single person, gathering data through the collection of stories, reporting individual experiences, and discussing the meaning of those experiences for the individual" (Creswell, 2008, p. 512).

Choosing narrative research as a methodology was partly inspired by my fellow cultural worker in the National Democratic movement, the late Alex Remollino, who beyond being a journalist in the Philippines as well as a poet, was a dear friend. Before he passed away in 2010, he told me in one of his journalism workshops he gave when he visited the US, "human face behind the stories has never failed." I took what Alex said to heart and remember it whenever I do cultural work. Taking this further, Reissman (2008) illustrates,

Many investigators are now turning to narrative because the stories reveal truths about human experience. Those who work with oral narratives of trauma survivors can see Isak Dinesen's wisdom at work: 'All sorrows can be borne if you put them in a story...tell a story about them.' Joan Didion extends the point: 'We tell ourselves stories in order to live' (p. 10). 
Narrative research as the methodology for this study was also chosen because, much like the cultural work that cultural workers in the National Democratic Movement of the Philippines produce, it has political implications and the potential to inspire action. This inspiration to act through cultural work, especially in the midst of political struggle, is what has allowed the National Democratic Movement of the Philippines to grow and thrive. As Reissman (2008) states,

Personal narratives can also encourage others to act; speaking out invites political mobilization and change as evidenced by the ways stories invariably circulate in sites where social movements are forming...In a word, narratives are strategic, functional, and purposeful. Storytelling is selected over non-narrative forms of communication to accomplish certain ends (p. 8).

Putting narrative in the context of cultural work, this is how the National

Democratic Movement of the Philippines was formed and continues to grow. The narratives produced through cultural work provided the counter narrative to the grand narrative being told by oppressive governments, similar to the Latin American testimonios that Reissman (2008) also mentions,

Stories can mobilize others into progressive action for social change. Major resistance movements in the twentieth century (including civil rights, feminist, and gay and lesbian movements) were born as individuals sat together and too stories about small moments of discrimination. Commonalities in the stories created group belonging and set the stage for collective action. For instance, oral testimonios got facts out in Latin American contexts regarding state-sponsored violence, helping to form revolutionary movements. These stories documented realities erased by governments in "official" documents (p. 9).

Narrative research, like cultural work, can also be a collective performance since it involves the audience in what is being produced. Cultural workers, when producing cultural work, always keep in mind who it is for and what social purpose it serves-will the audience identify with the cultural work being produced? Will they identify with it? 
Will they be inspired to take action? Taking this performative aspect to narrative research, Reissman (2008) illustrates,

To emphasize the performative is not to suggest that identities are inauthentic (although this reading is suggested by the dramaturgical perspective), but only that identities are situated and accomplished with audience in mind. To put it simply, one can't be a "self" by oneself; rather, identities are constructed in "shows" that persuade. Performances are expressive, they are performances for others. Hence the response of the listener (and ultimately the reader) is implicated in the art of storytelling. Including the audience as an active presence requires a shift in methods (p. 106).

\section{Research Setting}

There were two separate settings where the study took place: the Philippines, particularly in the National Capital Region of Metro Manila (NCR); and the United States, particularly the San Francisco Bay Area. Interviews took place in spaces where Filipino cultural workers convene to discuss and learn about the injustices they see happening in the communities with which they organize and how they will inform the art they create. Because cultural work is constantly on the move, interviews and field observations took take place at rallies, mobilizations, cultural events, and workshops.

\section{The Philippines: NCR}

Locations in the Philippines where interviews and field observations took place included the office of Concerned Artists of the Philippines (CAP), Popular Bookstore (which also happens to be staffed by members of CAP), and the BAYAN National office, all of which are located in Quezon City. One particular interview took place in front of a picket in front of the Department of Agrarian Reform (DAR) in Quezon City. This setting of the NCR, which includes Quezon City, was chosen because of my familiarity with the area. Aside from much of my family being from the NCR, this area is also where much of the cultural workers and organizations I am connected with are located. I became familiar 
with these organizations and cultural workers through my past Basic Mass Integrations (BMI), which I have participated on three occasions since 2006. All BMI's, especially those being participated by Filipino Americans or other internationalists, are processed through the BAYAN national office in the NCR. Although the National Democratic Movement of the Philippines has much activity in other regions of the Philippines, much of the political activity that gets national media attention happens in the NCR.

Events in the Philippines during the Summer of 2013 where the interviews and observations took place were at the political effigy and banner-making workshops led by the cultural organizations Ugat Lahi and CAP at the BAYAN national office during the weeks leading up to the annual People's State of the National Address (SONA ng Bayan), a large-scale political mobilization led by BAYAN that counters the president's SONA. The People's SONA always features the finished effigy, banners, and murals. The particular interview that took place at a picket line mobilization at the DAR was led by the peasant organization Kilusan Magbubukid ng Pilipinas (KMP). Because some cultural workers in the Philippines are constantly moving around between events and are always pressed for time, conversations took place over meals at their offices or small local restaurants.

\section{The United States: San Francisco Bay Area}

Events and places in the San Francisco Bay Area where interviews and observations took place during the Fall of 2013 are at the Filipino Community Center of San Francisco (FCC), where many cultural workers from organizations like Migrante Northern California, Gabriela-SF (formerly known as babae-SF), and NAFCON do their daily work as community organizers as well as produce their cultural work. 
The San Francisco Bay Area was chosen as a setting for this study because this happens to be where I live and organize as a cultural worker, as well as my close-knit connections with the various cultural workers and organizations also living in the area. This area was also chosen due to its long history of colonial and imperial connections to the Philippines, beginning with the Philippine-American war at the turn of the 20th century, where much of the U.S. military were deployed from. The Bay Area also has a long and proud history of political activism and cultural work since the Civil Rights Movement of the 1960's and 1970's, during which Filipino activists were among the strongest participants.

Events during this time of the study included the Filipino women's organization Gabriela-SF's annual cultural event "Diwang Pinay," and youth \& student organization League of Filipino Students at San Francisco State University's quarterly open mic event "Flip da Skript." To set the context of this time period, much of the political activity by cultural workers and Filipino organizations in the Bay Area revolved around Typhoon Haiyan, as previously mentioned. NAFCON, a national alliance of Filipino organizations in the US that also includes organizations with a National Democratic orientation, launched the Bayanihan Disaster Relief campaign and Taskforce Haiyan as grassroots efforts to raise funds for direct relief and rehabilitation operations in the Philippines in the wake of Typhoon Haiyan. The cultural work produced during this time period included education materials, fundraising events that showcased cultural work, and T-Shirts, just to name a few. Dependent on their availabilities, interviews were also conducted at their homes or wherever else would be more convenient for them. 
During the data collection at these events and areas, I was not just be observing the cultural work, but since being a cultural worker myself as well, I was also be participating in the cultural work to gain a full understating of the similarities and differences in the cultural workers and cultural work between the Philippines and U.S.

\section{Participants}

The participants for this study were selected from my own networks of activists and cultural organizations, all of which I consider cultural workers in the National Democratic Movement (though a few do not personally identify as such, which will be discussed in later chapters). Five participants in the Philippines and five participants in the Unite States were chosen, all of whom are cultural workers as poets, musicians, visual artists, videographers, theatrical performers, and writers. They are also community organizers and activists, and these are reflected in the cultural work they produce.

The participants interviewed were five Filipino cultural workers in the Philippines and five in the United States. Their ages range as young as mid-20's to as old as mid60's. Their styles of cultural work range from visual arts, music, poetry, literature, and film. As previously discussed, cultural workers are first and foremost organizers, so cultural workers represent the broad range of sectors they work with. These include, but are not limited to youth, students, workers, migrants, teachers, women, LGTBQ, and religious. All cultural workers interviewed are active participants in the National Democratic Movement of the Philippines, both in the United States and the Philippines. There are countless cultural workers in this social movement, but the particular cultural workers chosen for this research have produced cultural work in the movement for many years, have witnessed or experienced firsthand human rights violations and the struggles 
that inform their cultural work, and are well-respected by the National Democratic Movement of the Philippines.

\section{Cultural Workers in the Philippines}

For the participants in the Philippines, interviewees who are cultural workers in cultural organizations like Ugat Lahi and Concerned Artists of the Philippines (CAP), or members of progressive organizations who also happen to be well known cultural workers were chosen. The following are short biographies of these cultural workers in the Philippines.

- Ericson Acosta: Acosta is an activist who is currently a member of CAP and SELDA, an organization in the Philippines that advocates for the freedom of political prisoners. Acosta himself was a former political prisoner, having been illegally detained in February 2011 by elements of the Philippine military in Samar and faced trumped up charges of possession of illegal explosives, when in reality he was only carrying a laptop while conducting research on human rights in the area. After nearly two years of detainment, Acosta was freed in January 2013, largely due to the clamor for his freedom by his fellow activists in the National Democratic movement, both in the Philippines and internationally, who led the Free Ericson Acosta Campaign. As a cultural worker, he is a poet and songwriter, having written several poems and songs that speak to the struggles of the oppressed. He was also one of the founders of Alay Sining ("offering art") at University of the Philippines, Diliman, in the late 1990s, which is a National Democratic cultural mass organization.

- Bonifacio Ilagan: Ilagan is a member of CAP and does cultural work through the forms of theatre and film. He is currently a creative consultant for Kodao 
Productions, Southern Tagalog Exposure, and SIPAT, which are all independent film production companies that mostly document the political activities of the National Democratic movement. His latest works include the independent films Dukot ("abduction"), which is loosely based on the enforced disappearances of Melissa Roxas and Jonas Burgos; Sigwa ("storm"), which is based on the developments of a group of activists since the First Quarter Storm of 1970, a series of massive protests that ultimately led to President Marcos declaring martial law in 1972; and Migrante ("migrant"), which explores the plight of OFWs in the Middle East. All these films were featured in Cinemalaya, an independent film festival in the Philippines that is similar to renowned international film festivals such as the Cannes and Sundance film festivals.

- Axel Pinpin: Pinpin identifies himself as a full-time peasant organizer with KMP as well as a member of SELDA. He is also a renowned poet and writer, and his works speak to the injustices of society, as well as his experiences as a former political prisoner as part of the so-called Tagaytay 5. They were a group of activists illegally detained in Tagaytay, Philippines, by the Philippine National Police (PNP) and the Navy Intelligence Security Forces (NISF) in April 2006. They were accused of plotting to sow terror at a labor celebration at Malacanang Palace on May 1, 2006, but their trumped-up charges were dropped in August 2008 and were subsequently freed.

- Julie Po: Po is a member of CAP, and her family owns and runs Popular Bookstore in Quezon City, Philippines. Popular Bookstore features not only mainstream literature, but also a vast library of scholarly works on the National Democratic Movement of the Philippines. Other than the universities or publishers where these particular works 
were produced, Popular Books is one of the very few bookstores that house and sells works on the National Democratic movement (the other being the IBON Foundation bookstore). Much of the literature referenced in this study came from Popular Books. Aside from running Popular Books, Po is a visual artist and features her works at the bookstore. Locally, Po and Popular Books are considered “the masses' librarian and bookstore." These are the reasons why Po considers herself and the bookstore as part of cultural work.

- Max Santiago: Santiago has been a member of the Ugat Lahi (literally translates to "root race") artist collective since 1994. Ugat Lahi has been producing effigies for the annual People's SONA since the presidency of Fidel Ramos. The effigies, which are elaborate paper-mache floats featuring the corrupt Philippine presidents, are the main cultural feature of the People's SONA, which are then burned to the ground as an act of anger and resistance to the corrupt Philippine government. Santiago, along with Ugat Lahi, not only produce political murals and effigies, but conduct workshops on cultural work to teach that art should be used to expose social problems.

\section{Cultural Workers in the United States}

For the participants in the U.S., interviewees who are cultural workers and also members of community organizations were chosen. They range from activists born in the Philippines who migrated to the U.S., to those of Filipino descent born outside the Philippines who are also activists in the ND Movement.

- Mario "Nomi" Demira: Demira currently works as a workers' rights advocate at the Filipino Community Center (FCC) in San Francisco, CA, and is a member of Migrante-SF, an overseas chapter of Migrante International in the Philippines. As a 
cultural worker, he is the frontman for the Hiphop group Power Struggle, which is composed of him as the rapper and a collective of Hiphop producers and DJs. His most recent albums Remittances and the upcoming In Your Hands speak to his story as a Filipino migrant born in Nigeria to OFW parents who worked there as nurses, as well as the stories of the struggles of the working class and migrants. He has migrated throughout his life, from Nigeria, to Minneapolis, to New York, to currently in San Francisco. He has also used his art of Hiphop to organize local Filipino youth in San Francisco, conducting Hiphop workshops to help them tell their stories of migration and urban struggle through Hiphop.

- Elaine Villasper-Dizon: Villasper-Dizon is currently the Vice-Chairperson of Gabriela-USA, which is an overseas chapter of Gabriela Philippines. She was a founding member of babas-sf, now known as Gabriela-SF, a Filipino women's rights organization. She works as a anti-domestic violence advocate at the FCC in San Francisco. As a cultural worker, she is a visual artists and had produced works that reflect her life as a former undocumented immigrant from the Philippines, as well as the struggles and beauty of the Filipino people. Her works include paintings and graphic design, and her current project is Kulay Kalaayan (translates to "Colors of Freedom"), a website that features her works mainly targeted towards families and children. Such works include baby clothing with kid-friendly visuals about activism, alphabet picture flash cards with activist and Tagalog words, and family-oriented postcards and stickers.

- Joi Barrios-LeBlanc: Barrios-LeBlanc is currently an professor at University of California, Berkeley, in Filipino Language and Philippine Literature. She was a 
theatre artist and activist in the Philippines, as well as a former professor at University of the Philippines, Diliman. She was also a member of CONTEND (Concerned Teachers/Educators for National Democracy). Her current organizing work is alongside other concerned Filipino educators in California on the implementation of Assembly 123 in California, a bill which passed in October 2013 that aims to include the history of Filipino farmworkers in California as part of high school history curriculum. She is also a poet and songwriter, having written the script and songs for her recent play Piketlayn Cantana, which is about the plight of workers and migrants.

- Pendong Aban, Jr:: Aban is a musician from the Philippines, now living in Pacifica, CA. He was a member of the internationally renowned Philippine folk rock band Asin ("salt of the earth"), having performed around the world. One of their most famous songs, "Balita" ("news"), gained international fame when it was sampled by the Hiphop band Black Eyed Peas, whose member Apl.D.Ap (real name Alan Pineda) is from the Philippines. Aban currently makes music with his band, Ang Grupong Pendong, and co-composed many of the songs featured in Barrios-LeBlanc's Piketlayn Cantana. He is also organizing with faith-based Filipinos in the Bay Area around the issue of human rights.

- Marconi Calindas: Calindas is a visual artist from Laguna in the Philippines, now based in San Francisco, CA. He was part of Theatro Umalohokan during his college days at University of the Philippines, Los Banos, and in 1990 he was a charter member in forming the visual arts component. With Umalohokan, he produced street murals and during countless rallies and protests in the 1990s, as well as integrating in 
peasant communities conducting arts and theater workshops for them. He currently works as an independent visual artist in the San Francisco Bay Area, as well as workers' rights organizing with CPWR.

\section{Validity and Reliability}

When utilizing narrative research methods, the questions of validity and reliability are often raised. This is one of the things that make qualitative research, based on primary sources like oral histories, different from quantitative research, which is based on statistics and figures. Qualitative narrative research involves a lot of personal interviews, focus groups, and oral histories. The question of if what the participant is sharing "valid" or "reliable" then becomes a site of struggle when doing narrative research, as it pertains to the academy. Reissman (2008) highlights this,

When applied to narrative projects, two levels of validity are important - the story told by the research participant and the validity of the analysis, or the story told by the researcher. There has been a long debate in the social sciences about "truth" (although trustworthiness is a better term) - a debate with long taproots in philosophy. Recently, questions about reliability and validity have resurfaced with the growing desire among some U.S. survey researchers to give their work a human face by weaving qualitative components (including life stories) into their projects (p. 184).

Validity and reliability, in a traditional research sense, is difficult to apply to narrative research, especially when this study is critical and decolonizing in orientation. Reiterating my colleague Alex Remollino's memorable words, "human face behind the stories has never failed," applying traditional notions of validity and reliability to a study such as this can be potentially dehumanizing, especially if it regards the researcher and observer as not a participant in the narratives of those in the study. Quoting Norman Denzin in a 2003 NSF [National Science Foundation] document, Reissman (2008) takes this point further, 
'Complex literatures are now attached to research methodologies, strategies of inquiry, interpretive paradigms, and criteria for reading and evaluating inquiry itself.' Instead, the model of a detached, disinterested, and disengaged observer is valued in the guiding documents. Fixed criteria for reliability, validity, and ethics developed for experimental research are recommended and misapplied; they are not suitable for evaluating narrative projects (p. 184-185).

This is where I borrow elements from Participatory Action Research (PAR) - though this methodology was considered; in that just like PAR, narrative research also has the potential to organize those being researched, the researcher, and readers into collective political action. The researcher, in this case myself, is not the expert of this study. It is those being researched, the cultural workers themselves who have witnessed and experienced oppression at varying levels, that are the real experts. There is nothing more valid about studies of oppression and injustice than those based on the stories of those who experienced or are experiencing oppression firsthand. Cammarota \& Fine (2008), illustrate this element of PAR further,

Classic social science is measured, in part, by the extent to which "experts" consider the design and constructs to be valid. I want to pause for a moment to consider how PAR transforms and deepens this notion of expertise. PAR stands on the epistemological grounds that persons who have historically been marginalized or silenced carry substantial knowledge about the architecture of injustice; in their minds, bodies, and souls; in ways that are conscious and floating; individual and collective (p. 223).

This study is not to just do research to produce knowledge about this subject, but to humanize and give honor to those who produced this knowledge in the first place, the cultural workers - the experts, themselves. By doing so, it also humanizes the study and adds authenticity to the knowledge produced. Cammarota \& Fine (2008) also point out this break away from traditional notions of validity and reliability,

I want to tie this commitment to plural and subjugated expertise to the traditional standard of expert validity because participatory action research projects are designed expressly around a set of processes to honor and develop these varied 
bases of knowledge in youth and in adults, explicitly troubling hegemonic and hierarchical assumptions about who is the expert (p.223).

This humanization of the study is one of the reasons narrative research, with borrowed elements from PAR, was the chosen methodology. As Mayotte (2013) illustrates, narratives are used to "to reject the dispassionate stance of traditional social science, adopting instead a capacity for empathy and identification, for greater joy and immense indignation and, above all, a willingness to be changed in the process" (Mayotte, 2013, p. 7). Cammarota \& Fine (2008) take this notion further, noting the political implications it can have in upsetting the traditional rigidity of research, which I would argue can be hegemonic in upholding a certain status quo,

Participatory action research is a strategic tool anchored in some very untraditional formulations of some very traditional notions of objectivity, validity, and generalizability. With innovation and a proud legacy of activist social researchers, participatory research collectives can interrupt the drip feed, engage critical questions, produce new knowledge, provoke expanded audiences, and allow us to ask as scholars, in the language of the poet Marge Piercy (1982), how can we 'be of use?' (p. 231).

There is a certain trust that is made among the participants and researchers when using narrative research using elements of PAR. It almost asinine to assume that an oppressed person would lie about being oppressed or witnessing oppression. If anything, the recurring stories of human rights violations and how it informs cultural work are all valid and reliable, if going by how often these incidents occurred.

\section{Data Collection}

Data was collected by conducting interviews, personal narratives, and participant observation field notes with cultural workers. I was integrated in the research setting "to get close to those studied as a way of understanding what their activities mean to them" (p.191). This method is very similar to what many activists in the National Democratic 
Movement of the Philippines already do, in what is called a BMI, or Basic Mass

Integration. This is mostly done with the peasants, workers, and urban poor in the

Philippines to understand the concrete conditions of the struggles they face, a strong

example of Lather's (1986) research as praxis.

For praxis to be possible, not only must theory illuminate the lived experience of progressive social groups; it must also be illuminated by their struggles. Theory adequate to the task of changing the world must be open-ended, nondogmatic, informing, and grounded in the circumstances of everyday life; and, moreover, it must be premised on a deep respect for the intellectual and political capacities of the dispossessed (p. 262).

\section{Interviews}

Each face-to-face interview was loosely structured which allowed for open

dialogue. This open dialogue was purposeful, rather than a structured interview. Although a set of questions was prepared, I allowed for open conversation as many participants answered some questions ahead and sometimes I had to go back to questions not yet answered or skipped. This allowed for a more collaborative process of the participant sharing their narrative. As Reissman (2008) also mentions,

In his (now classic) book, Mishler reconceptualizes research interviewing as a discursive accomplishment: the standardized protocol (where question order is invariant) gives way to conversation where interviewees can develop narrative accounts; speaker and listener/questioner render events and experiences meaningful - collaboratively. The model of a 'facilitating' interviewer who asks questions, and a vessel-like 'respondent' who gives answers, is replaced by two active participants who jointly construct narrative and meaning (p. 23).

The conversations between each participant and myself were recorded via either video or audio, depending on each participant's comfort level. I then transcribed and coded each recording. 
Table I.

\begin{tabular}{|c|c|c|}
\hline Interviewee & Setting and Date of Interview & $\begin{array}{l}\text { Length of } \\
\text { Interviews } \\
\text { (approx.) }\end{array}$ \\
\hline Axel Pinpin & $\begin{array}{l}\text { Picket by KMP in front of Department of } \\
\text { Agrarian Reform; Quezon City, Philippines. July } \\
\text { 14, } 2013 \text {. }\end{array}$ & 1 hour \\
\hline Julie Po & $\begin{array}{l}\text { Popular Bookstore, Quezon City; Philippines. } \\
\text { July 1, } 2013 .\end{array}$ & 1 hour \\
\hline Max Santiago & $\begin{array}{l}\text { Garage of BAYAN National Office, effigy- } \\
\text { making workshops for SONA ng Bayan; Quezon } \\
\text { City, Philippines. July 15, } 2013 \text {. }\end{array}$ & 1 hour \\
\hline Bonifacio Ilagan & $\begin{array}{l}\text { Concerned Artists of the Philippines' Office; } \\
\text { Quezon City, Philippines. August 2, } 2013 .\end{array}$ & 1 hour, 15 minutes \\
\hline Ericson Acosta & $\begin{array}{l}\text { Coffee shop at University of the Philippines, } \\
\text { Diliman; Quezon City, Philippines. July 28, } \\
2013 .\end{array}$ & 1 hour, 30 minutes \\
\hline Mario DeMira & $\begin{array}{l}\text { Demira's apartment; San Francisco, CA, USA. } \\
\text { November 4, } 2013 .\end{array}$ & 1 hour, 15 minutes \\
\hline $\begin{array}{l}\text { Elaine Villasper- } \\
\text { Dizon }\end{array}$ & $\begin{array}{l}\text { Villasper-Dizon's apartment; Daly City, CA, } \\
\text { USA. November 7, } 2013 .\end{array}$ & 1 hour \\
\hline Joi Barrios-Leblanc & $\begin{array}{l}\text { Workers' rights training; Daly City, CA, USA. } \\
\text { December 7, } 2013 \text {. }\end{array}$ & 1 hour; 15 minutes \\
\hline Pendong Aban, Jr. & $\begin{array}{l}\text { Workers' rights training; Daly City, CA, USA. } \\
\text { December 7, } 2013 \text {. }\end{array}$ & 1 hour; 15 minutes \\
\hline Marconi Calindas & $\begin{array}{l}\text { Workers' rights training; Daly City, CA, USA. } \\
\text { December 7, } 2013 \text {. }\end{array}$ & 1 hour; 15 minutes \\
\hline
\end{tabular}

\section{Fieldnotes and Observations}

Fieldnotes and observations provided a record of understanding of the cultural workers' lives and events. Emerson et al (1995) provide insights for the basis of using field notes in this chosen methodology:

(1) What is observed and ultimately treated as 'data' or 'findings' is inseparable from the observational process. (2) In writing field notes, the field researcher should give special attention to the indigenous meanings and concerns of the people studied. (3) Contemporaneously written field notes are an essential 
grounding and resource for writing broader, more coherent accounts of others' lives and concerns. (4) Such field notes should detail the social and interactional processes that make up people's everyday lives and activities (p. 11).

This method of data collection took place from June 2013 to December 2013, utilizing field notes during and/or after the events, filming or voice recording depending on the participant's comfort level. Interviews took 1-2 hours to complete, not including casual conversations about cultural work that may take place during events, which were also be documented in the field notes with the permission of the interviewees. After these were gathered, the data was transcribed, and for the Filipino cultural workers living in the Philippines, translation from Tagalog (one of the national languages of the Philippines) was also done.

\section{Table II.}

Field notes

\begin{tabular}{|l|l|l|}
\hline Event & Setting and Date of Event & $\begin{array}{l}\text { Length of Data } \\
\text { Collection for Field } \\
\text { Notes (approx.) }\end{array}$ \\
\hline Picket led by KMP & $\begin{array}{l}\text { Department of Agrarian Reform, } \\
\text { Quezon City, Philippines. July 14, } \\
\text { 2013. }\end{array}$ & 30 minutes \\
\hline $\begin{array}{l}\text { Effigy-making for SONA ng } \\
\text { Bayan, led by Ugat Lahi; and } \\
\begin{array}{l}\text { CAP meetings and educational } \\
\text { discussions. }\end{array}\end{array}$ & $\begin{array}{l}\text { BAYAN National Office, Quezon } \\
\text { City, Philippines. July 8-21, 2013. }\end{array}$ & 20 hours \\
\hline $\begin{array}{l}\text { Bay Area Taskforce Haiyan } \\
\text { meetings and events. }\end{array}$ & $\begin{array}{l}\text { Various locations in San Francisco, } \\
\text { Oakland, Daly City, and Pacifica, } \\
\text { CA, USA. November 11-December } \\
\text { 20, 2013. }\end{array}$ & 60 hours \\
\hline $\begin{array}{l}\text { Diwang Pinay, a women's } \\
\text { cultural event by Gabriela-SF. }\end{array}$ & $\begin{array}{l}\text { Bayanihan Community Center, San } \\
\text { Francisco, CA, USA. December 8, } \\
\text { 2013. }\end{array}$ & 3 hours \\
\hline
\end{tabular}




\section{Data Analysis}

The questions directed to the participants were designed to answer the research questions that led to this inquiry: (a) According to cultural workers, what is cultural work and how does it look in a transnational context? (b) How is cultural work used in the National Democratic Movement of the Philippines? (c) What are the implications of cultural work for marginalized communities?

After transcription of the dialogue, I analyzed the data and coded the transcription of each dialogue I had with each participant. According to Creswell (2008), "coding is the process of segmenting and labeling text to form descriptions and broad themes in the data" (p. 251). After all data was collected, transcribed, translated, and coded, I searched for common themes that emerged from the answers that were given by the cultural workers. Because narrative research is used as the methodology, narrative analysis was used in the coding part of the study. According to Reissman (2008),

...analysts...preserve sequences, rather than thematically coding segments. In narrative analysis, we attempt to keep the "story" intact for interpretive purposes, although determining the boundaries of the stories can be difficult and highly interpretive (p. 74).

Because attention was also given to time and place of narration in this study, narrative analysis historicizes the stories, and thus "rejects the idea of generic explanations" (Reissman, 2008, p. 74). By keeping the stories of the cultural workers intact, it not only provides historical context, but also humanizes the stories, which is a central theme in narrative research.

\section{Ethical Considerations}

For Filipino cultural workers who are from the Philippines but now living in the United States as undocumented immigrants, pseudonyms were used to protect the identity 
of such cultural workers. Another ethical consideration was approaching Filipino cultural workers with a high degree of sensitivity, especially towards those who may have been survivors of, or who maybe have witnessed human rights violations such as violent physical intimidation, detainment, torture, and extrajudicial killings. 


\section{CHAPTER IV}

\section{FINDINGS}

As previously discussed, the purpose of this study is to examine the extent to which cultural work brings political consciousness to marginalized populations who do not have access to education. Another objective is to examine the impact of cultural work locally and transnationally as a tool for social change and for addressing issues that impact marginalized populations, particularly in the National Democratic Movement of the Philippines.

The following findings of this study are organized into the research questions that led to this inquiry: 1) According to cultural workers, what is cultural work and how does it look in a transnational context? 2) How is cultural work used in the National Democratic Movement of the Philippines? 3) What are the implications of cultural work for marginalized communities?

As detailed in Chapter III, the qualitative method used for this study was narrative research, particularly storytelling and oral history (p. 79). Given that this topic is on cultural workers in the National Democratic movement of the Philippines, cultural work is used to give voice to the oppressed, marginalized, and voiceless. Narrative research, used in this context, provides the space for this. Narrative research as the methodology for this study was also used because, much like the cultural work, it has political implications and the potential to inspire action. This inspiration to act through cultural work, especially in the midst of political struggle, is what has allowed the National Democratic Movement of the Philippines to grow and thrive. The data for this study was gathered through face-to-face open dialogues between the participants and myself, 
allowing them to share their own narratives on transnational cultural work in the National Democratic Movement of the Philippines.

\section{Research Question 1: According to cultural workers, what is cultural work and how does it look in a transnational context?}

In my conversations with the cultural workers, they had many common definitions of cultural work and cultural workers, as well as their own roles in the National Democratic Movement in the Philippines beyond the borders of the Philippines. As stated in Chapter II, cultural work is the use of the various forms of art with the purpose of social change (p. 11). Furthermore, they push for a reclaiming and redefinition of culture that has been smothered and silenced by the avalanche of Western imperialism (p. 15). As with the National Democratic Movement of the Philippines, cultural work also transcends the national borders, as Filipino cultural workers in the diaspora are not just reflecting the oppressive neocolonial society in the Philippines, but connecting that struggle to other struggles wherever they are in the world. This is one of the reasons why the National Democratic Movement of the Philippines and its cultural work is referred to as "counter hegemonic (trans)nationalism" (Rodriguez, 2010, p. 152)

\section{Defining Cultural Work and Cultural Workers}

Resonating with cultural work as transcendent, Axel Pinpin recollects how the term cultural work came about in the National Democratic Movement.

It developed in itself, within the National Democratic Movement, that term cultural work. It's not very popular, you don't hear that in the mainstream. What I want to say is unlike classical or what is called traditional Filipino culture, in terms of arts and culture, there is a culture with a national democratic orientation. Because of the kinds of marches, the kinds of poetry that ends with an exclamation point, the kinds of dances that moves in tempo with fists raised; maybe it's become our stereotype, but it's come to be appreciated. In the last 
decade, there's been larger attempts to popularize the National Democratic Movement, to penetrate the mainstream (Interview July 14, 2013).

According to cultural workers, they are deliberate in popularizing the National Democratic Movement and its orientation, because cultural work is what will garner broad support. One of the ways to do that is to penetrate the mainstream, as Pinpin stated. I remember being in the Philippines during my Basic Mass Integrations in past years, where cultural workers have flipped mainstream pop songs by changing the lyrics to words that addressed the problems in society. A few examples were the pop songs "Price Tag" by British pop singer Jessie J, as well as "On the Floor" by American pop singer Jennifer Lopez, but cultural workers flipped the lyrics to address sex trafficking and human bodies as labor commodities, reflective of the actual struggles of people who experienced these injustices. Their versions of these pop songs were a hit with the audiences at several rallies as well as on YouTube. Pinpin also feels this is a very effective way of penetrating the mainstream to get the message out more broadly. It also changes mainstream art from just reinforcing the escapism and decadence of imperialist culture to art that is more relevant to people's struggles.

So for example, we can adopt verses of pop songs to make us radio-friendly. Like can you imagine using Lady Gaga songs? You can, because the masses know her! For the understanding of the masses, or even the peasants who I serve, for my poems I start from their point of view. For a true appreciation for art, it's not from the thinking of 'art for art's sake.' It's how will the art be used to serve society. Until society changes, until there's a change in our relation to production-for example, when the peasants become owners of their land; until such a time there's an understanding of production to the land, especially for the peasants, there will always be that reason for art to serve society. They like to hear the poems, they like to listen to our revolutionary music, because they are tied to them - they are tied to their struggle for land. If you don't address to their particular interests, then it's just trash to them. That leads us to why not penetrate using radio friendly means? The romanticized love songs, the decadent lifestyles, the other putrid topics - that's the creation of imperialist society, especially of the U.S., that escapism of what's happening now (Interview July 14, 2013). 
Cultural workers also see cultural work in terms of culture as a whole, not just the art. This is a reason why the arts in the National Democratic Movement of the Philippines is called cultural work, to be wholly reflective of all the aspects of the culture we are living in. Boni Ilagan shared his experience with learning of the terms cultural worker and cultural worker.

When I joined the movement in the late 1960s, I was into theater, and I just heard the term cultural worker. So I was being referred to not as a theater artist, but as a cultural worker. Now that you ask the question, I think it is in the appreciation of the work as a whole. Of course, when we say theater, that is a very specific field of art. When we say music, that's another very specific field of art. But when we started doing theater in the activist movement, we were also employing the other fields of art. We did not define the fields in their specific functions. We saw theater as one complete performance, and if you were someone who knew how to play the guitar, you would be in. If you were someone who could move or dance, you'd be in. I was not called a playwright at that time, neither was I called a director. We were all called cultural activists. I think it also harks back to our study of culture as one big chunk of the whole social structure, and in culture there would be education as in schools, there would be religion as in churches, and of course the arts. So when we do our mass work, we would try to talk with the people, not in terms of theater or music or visual arts, but we would talk in terms of the whole (Interview August 2, 2013).

Ericson Acosta shared a concise and sharp definition of cultural work and cultural workers. He also added that unlike the individualism of mainstream art, it is a collective process that guides the progressive organizing work towards social change. This resonates with the perspective of cultural work being not peripheral, but central to social movements.

The term 'cultural work' is an operational term of progressive art and literature. Using that underscores the role progressive art and literature in the cultural movement. It also redirects the propensity of artists and writers to become individualists, or to encourage them not to look at art and literature as sacred in a very individualist or obscure way, or being above politics, or above the political, socioeconomic movement. You have the National Democratic Movement, in which cultural work structures its organizations, and they practice it (Interview July 28, 2013). 
Practicing cultural work not only necessitates the collective process, but it also involves cultural workers placing themselves with and of the communities they work with. By doing so, they learn and internalize the struggles of marginalized communities, which then informs the cultural work they produce. The cultural work produced not only reflects the stories and struggles of marginalized communities, but is done with the purpose of using cultural work for social change. As discussed in Chapter II of cultural workers being ATORs (Artist-Teacher-Organizer-Researcher)(p. 26), Joi Barrios-Leblanc reiterates this important framework of cultural workers.

I think the influence there had a lot to do with theater and culture for education, that framework. That framework, to a certain extent, was largely disseminated by people from PETA, the Philippine Educational Theater Association, and other people in the cultural movement, in redefining arts, looking at artists as ATORs. I think because people have what you might call a deeper movement in the National Democratic struggle, that informs that informs the cultural work, within the framework of the National Democratic struggle. So it's not 'art for art's sake.' There's a purpose. As a cultural worker, you have a role in the community. You have to look at the economic, political, everything as a whole. It also less about the individual as an artist, but more about collective production of art. It doesn't mean you don't just produce individually, because you do. When you write a poem, it's your poem. And when you paint, it's your painting. But you produce as part of many people also producing art, with the same goals of social change (Interview December 7, 2013).

Above all, the most important role of a cultural worker is that of organizer. Even Axel Pinpin, although does not mind the label cultural worker, does not consider himself as such. To him, his most important role is full-time peasant organizer. For him, it is more important be known as an organizer, because he feels that the label cultural worker is still seen outside of the movement as just an artist, or safer than organizer. Pinpin shared that while he does not mind being called a cultural worker, he does not want to be seen as "safe," but as an organizer bold enough to disturb the status quo. When we were 
at the peasant's picket camp in front of the Department of Agricultural Reform in Quezon

City, and I first asked him about being a cultural worker, he was quick to respond,

That's an interesting question, because I'm not a cultural worker. It just incidental that I'm a poet. I want to make it clear that I'm here in the picket camp not as a poet, but as a peasant organizer. In fact, I haven't been writing much up to now. This daily regimen ought to inspire me, but this political work is demanding, so I haven't been writing as much. But in due time, since it's all stored in my head, I will write. So for cultural workers, they need to be rooted in the basic sectors. They can't be inspired just because one peasant got shot. They need to be sensitive to the spilt blood of the peasants. They need to understand the muddiness - the struggles, the peasants go through (Interview July 14, 2013).

For Pinpin, struggle is an essential component of being an organizer. Thus, it is more important to be on the ground organizing and being close to the community, in his case the peasants, which then informs the poetry he writes, which for him comes secondary. This closeness with the community and organizing with them is the main role for any cultural work, above the art they produce. Julie Po shares this same sentiment:

Cultural workers basically should be organizers. Their distinct task is to use arts and literature with their organizing tasks and in their productions. Because of the cultural work being produced, it is easier to play to the people, and it will stick in their hearts and minds. I would not say cultural workers are unique because everyone should be organizers. Maybe it's a different task from other organizers, but I do not want to say that the cultural workers are special just because they are artists. They should be organizers, they should also be in the communities. That is where they will get their content, from the people. That will enrich their creativity even more (Interview July 1, 2013).

This perspective is what differentiates cultural workers from artists, in a traditional sense. Having this perspective not only helps to organize the oppressed basic sectors of society, but it also helps in organizing traditional artists as well in using their art for social change. The task of thinking beyond just aesthetics, but also how to use the aesthetics to draw people into the movement, is a skill that artists can share. Max Santiago reflected on this particular skill: 
So being a cultural worker, we have many tasks. We can't just focus on the artistic side. We have to think it's not just about you being an artist, but how would you communicate with the audience, and how would you interact with other artists and maybe recruit them, or make them join with your cause. That's also part of the work being a cultural worker. You just don't paint or create, you also organize. It's difficult, but it has to be done if you want to expand. If you want our cause to be heard by more people, you have to organize more artists (Interview July 15, 2013).

Hearing Santiago's reflection reminded me of a quote by Kenyan writer Ngũgĩ wa Thiong'o (1993), whose works on theatre are similar to the tradition of Augusto Boal's Theatre of the Oppressed. His quote stresses the importance not of the beauty of the aesthetics, but of the function it plays in expanding ways of thinking, much like the role of a flower's beauty is to carry seeds. He said, "Culture has been rightly said to be to society what a flower is to a plant. What is important about a flower is not just its beauty. A flower is the carrier of the seeds for new plants, the bearer of that future of that species of plant" (p. 56-7). Much like the beauty of a flower, what is more important is not the aesthetic beauty of cultural work, but the organizing it entails for sparking people's consciousness and organizing themselves into the movement.

This main role of organizer, and artist being secondary, is what guides cultural work. This goes against status quo notions of "art for art's sake" and artists as individualistic. Mario Demira stresses this distinction of cultural worker from "progressive artist," which is what he defines as an artist who uses themes of social change in the art they produce, but is absent from the actual organizing. These kind of artists are not directly involved in progressive social movements, but are rather commodifying them for their own purposes. Demira resonates with the importance of cultural workers being directly involved in the movement. 
Cultural workers think about ourselves as trying to influence our society in a progressive and positive way. I encourage in all creative people and progressive artists to not just leave their work in the studio, or on stage, or the canvas or gallery, or wherever, even if they're a graffiti artists on the street. They need to go beyond and put their words and creativity into motion. And if you're a progressive artist, if you're talking about social justice or revolution, then you should actively participate in the step-by-step tasks of organizing people, of building power in communities. It should be more than just performing at a show, or doing a benefit event. Even though that shit is great, and I encourage it, but I make a friendly challenge to see yourself not just having the badge of 'I'm an artist and I'm doing it for the community, and I'm progressive, so I'm a cultural worker.' That's cool, but challenge yourself to be a part of people's organizations, facilitate meetings, take on a task, take on a role in the group. And I think that is what will help you not only maintain, but even understand more the importance of your art (Interview November 4, 2013).

The building of power in communities which Demira mentioned is essential to movement building. Echoing this sentiment, Elaine Villasper-Dizon sees this direct integration and involvement of cultural workers in the communities they serve as their main responsibility, being organizers first and foremost. If the objectives of cultural work are changing the oppressive culture we live in and building the culture we want for ourselves, this responsibility is of utmost importance, above the art that is produced. VillasperDizon stresses this responsibility.

What I have come to understand about cultural work is we can't just make art to reflect and change the culture that we're part of. We have a responsibility to also to engage in the work that it takes to build the culture that we want to see. It's part of our responsibility as cultural workers to engage in organizing, to engage in advocacy, to do mass work, and all of that comprehensively contributes to you as an artist and the way that you create art, whatever medium or form that you choose (Interview November 7, 2013).

The common thread for these cultural workers is that the main role is that of organizer. What that means is that a cultural worker is not just an artist, but more importantly is a citizen of society, echoing Lino Brocka's Artist as Citizen. Cultural workers are directly involved in the communities they are part of and struggling 
alongside with, using their role as ATORs to practice Boal's poetics of the oppressed, and in the process become what Cornel West describes as Critical Organic Catalysts, as discussed in Chapter II (p. 19). By being directly integrated in the everyday lives of the oppressed, cultural workers along with communities they serve create a culture of critique and resistance, which according to them is the culture and society they want to see for themselves.

\section{The Role of Cultural Work Transnationally}

Being that the National Democratic Movement of the Philippines extends beyond the borders of the Philippines, the same goes for its cultural work. It is one of the ways for Filipinos in the diaspora to stay connected to the struggle in the Philippines. But beyond staying connected to the struggle, cultural work also bridges styles of art used to advance the movement. Axel Pinpin highlighted this bridge when we were conversing at the KMP picket in front of the Department of Agrarian Reform, which also happens to be alongside a very busy and noisy street in Quezon City. As we were conversing, we found ourselves bobbing our heads to the familiar sound of Hiphop music was playing in one of the jeepney trucks that arrived at the picket.

Just a while ago, one of our jeepneys arrived with the youth of the KMP members picketing here. And they were playing loudly that rap song by the Fil-Am (Filipino-American) rapper, Kiwi - the one that goes "Makibaka!" (Struggle on!). In my eyes, that's a big help, because in the First World, First World terms are in Third World culture. If you adopt those, you can penetrate the masses. When Hiphop came to the Philippines, it was appreciated immediately. There's been many attempts here to do that too, and I'm not against comrades who attempt to rap or use rap music, as long as it doesn't compromise our political line. I'm very particular about our political line. It's very fitting that Fil-Ams and internationalists integrate with the comrades here and share influences. You become aware of the status of our countrymen. I believe that you can create your arts based on your experience. I believe that the cultural work abroad is a big help, that we see the artworks, the music, the compositions - we see on the internet all your activity. It's in the back of our minds here in the homeland, that 
even in the imperialist country, the struggle of our people is alive (Interview July 14, 2013).

The song Pinpin was referring to, whose lyrics are in both Tagalog and English, was a song Kiwi produced based on his basic mass integration with urban poor youth in the Philippines back in 2007. It was great to see that the youth he integrated with back then were still playing his music, which reflected their struggles and resistance to oppression. With the Philippines having one of the longest histories of Hiphop culture in Asia, many youth in the Philippines continue to identify with it, as it was a culture born out of the struggle and resistance of youth of color in the U.S. Hiphop music is one of many ways used by cultural workers to advance the National Democratic Movement and to connect the struggles of all oppressed peoples worldwide. Mario Demira, another FilipinoAmerican rapper who has also done basic mass integrations in the Philippines, primarily uses Hiphop in his cultural work, connecting his own experiences as a migrant with the struggles of marginalized communities in the Philippines. He highlights that the struggle of one community is the struggle of all communities, no matter where they are in the world.

I think it's dope that we live in different places, are influenced by different genres, but the themes of justice and equality are universal. I think it would be whack if just because I was wanting to connect to the Philippines, I deny the fact that I grew up loving Hiphop and then just start doing indigenous music just because I felt like I would be more connected. That's not right. I think that we have to be able to tell our stories in a way that we feel most comfortable, and the connections will be made when we listen to those lyrics and messages that we're putting out. That's why it's very important and useful to work in genres in a transnational sense. Like if a Hiphop artist here talks about the struggle of his life at home, and his parents are beefing with him, why his mom never around because she's always working and sending money to the Philippines, and is underpaid, exploited, all of that; the same artist in the Philippines will talk about how his mother is gone because she had to work abroad. That's one example of connecting to the contradictions in the Philippines (Interview November 4, 2013). 
What Demira just described was how cultural work builds the connectedness of Filipinos in the diaspora back to the Philippines. It is through cultural work in the National Democratic Movement that this bridge back to the Philippines builds nationalism beyond just the nation state. In this sense, it also complicates notions of "transnational" as simply a transfer of funds, like Demira described, but more so a transnational social movement built on "counter hegemonic (trans)nationalism" (Rodriguez, 2010, p. 152)

This connecting of struggles through cultural work is of importance not just for the National Democratic Movement of the Philippines, but for all people's movements in other countries. Cultural workers in the National Democratic Movement of the Philippines believe that the victory of one people's movement is a victory for all people's movements. Boni Ilagan pointed out the connections of all people's struggles through cultural work as one transnational people's movement.

If the world is truly becoming global, I think it is culture that should transcend boundaries, that should tear down borders. And the one thing that should be able to strengthen any people's movement, in any country, would be a sharing of culture. So in terms of that, it would definitely expand the front, the cultural front, in the Philippines if activists here would be able to learn more about the culture of other peoples in struggle. Definitely, it's going to help if cultural work in the Philippines could be shared with other activists wherever they are in the world. Because in that sharing, we'd be able to identify the common grounds for unity, the common grounds for cooperation. And what is your way to do that but through the arts, through culture (Interview August 2, 2013).

Julie Po shared this same sentiment, believing that with the world becoming global, the victories of the National Democratic Movement is not just for the Philippines, but for all people's movements.

Cultural work abroad is a very big boost to the ND movement here in the Philippines. If you're talking about globalization now, this national democratic movement, at some point, will not just be for the Philippines, but also for other countries' progressive movements. But of course, our hearts will always be with the Philippines (Interview July 1, 2013). 
For cultural workers who have migrated from the Philippines, cultural work is a way for them to stay connected to the struggle in the Philippines, as well as to raise the awareness of what is going on in the Philippines, despite being far away. Marconi Calindas shared that he feels still very much connected to the Philippines through his cultural work, despite now living in the U.S. It is also important for him that cultural work be used to reach out to Filipino-Americans who may have grown up being disconnected from the Philippines.

For the majority of us who continue to work as cultural workers here in the U.S., we're actually transplants. We have history of why we're doing this. We were doing that in the Philippines, and now that we're just geographically relocated here in America, that doesn't mean that we're going to stop supporting what we do for change in our beloved country, the Philippines. So what we do here is we continue, with regard to our cultural work, and our art forms that we know can actually transform people to engage in discussions in helping our brothers and sisters in the Philippines. It's also, when talking about the Filipino-American community that you need to reach out to, a community that seems to be disjointed from what's happening in the Philippines (December 7, 2013).

This responsibility of using cultural work to bridge the struggles of Filipino Americans to the Philippines and vice-versa, is one that Elaine Villasper-Dizon has personally identified with, being a migrant herself who has lived half her life in the Philippines and the latter half in the U.S. What is shown in U.S. mainstream media about the Philippines is all that is begin shown, which is promotes the face value of tourism but neglects to show the harsh realities of poverty and oppression.

I think coming from my life experience, it's really a bridge for Fil-Ams. When people look at the Philippines, they kind of see this fake Philippines. They see the dichotomy - they see Boracay beaches, the Cordillera Rice Terraces, they see beautiful places. And then they know that there's squatters in shantytowns, and that's it. That's the only narrative that comes out of the TV or radio about the Philippines. I think for me as a first generation migrant, as a former undocumented migrant, I really feel a sense of responsibility to tell people in the U.S., not just Filipino but really anyone who is willing to listen, that there's a 
beautiful country that's thriving in the Philippines, and to reflect what that looks like. But at the same time, connect it to the life, struggles, and challenges that we're facing, that we're living here in the U.S. I think it's reflective and necessary for me to reflect that in the themes that I take up in the artwork that I produce, in the types of shows and events that I participate in, the topics that I take up when I'm not just creating artwork but also engaging in other organizing work, and what purpose my artwork is for (Interview November 7, 2013).

Another responsibility of cultural work outside of the Philippines, as with any activist in the National Democratic Movement, is highlighting the reasons Filipino are forced to leave the Philippines in the first place. There are root problems in the Philippines, like most third world countries, that make life so difficult that people migrate to find work abroad out of survival. The National Democratic Movement of the Philippines has an analysis for that, which Villasper-Dizon discussed.

The reason why people in the Philippines are suffering, the reason why they're having a very hard time surviving, is the very same reason that our families were forced to migrate here, and are still suffering. We in the ND Movement have an articulation for the reasons for that-it's the three basic problems of imperialism, feudalism, and bureaucrat capitalism. The reason why we're even here in this country, the reason why were facing racism, homophobia, all of these other things that were facing here in this country, is because we couldn't live and survive in our home country. That was how I saw myself being drawn to the ND movement. I wasn't being reflected in America, and I didn't feel like that was fair. At the same time, the alternative narrative, if you believe it, is that you have a bad life because you don't work hard enough, or because you did bad things. The ND movement and its analysis gave me a deep understanding that I'm here because of what's happening in the Philippines. And for me, the way imperialism is now, it's global and doesn't live just in America. It's connected to a lot of people's home countries, the Philippines being one of them. We can't talk about the oppression that we face here, the people getting scapegoated for immigration things, we cant talk about those things without talking about colonialism, without talking about the long history of oppression that our people have been facing in the Philippines, and how it's connected to our experiences here (Interview November 7, 2013).

What makes the role of cultural workers and activists in the National Democratic Movement of the Philippines unique is combatting U.S. imperialist culture. And this role is of particular importance for cultural workers ling in the U.S., within what many 
activists called "the belly of the beast." Ericson Acosta, who has never been to the U.S., highlights this importance for cultural workers in the U.S. working to advance the National Democratic Movement abroad, first beginning with organizing the most exploited class in the U.S., which is the working class.

It's a big help, definitely, in consolidating those in the exodus. In the U.S., the belly of the beast, I could just imagine how hard it is. If it's already hard in the Philippines, how much harder it is for you guys given your circumstance. I mean, you're in the U.S. for Christ sake! You're in the center of bourgeois imperialist culture. But of course it's not impossible. You still have a working class in the U.S. The way it's supposed to be done in the working class is basically the same way of organizing, starting with the most oppressed sector of society (Interview July 28, 2013).

Filipino Americans have had a long history of activism in the U.S., as discussed in Chapter II. When I first started becoming involved in the National Democratic Movement of the Philippines back in 2004, I naturally questioned if what Filipino American activists do in the U.S. has any impact on the movement in the Philippines. Through my basic mass integrations in the Philippines over the years, I have learned that one Filipino American activist in the U.S. holding a placard that says "Down with U.S. Imperialism!" at a mobilization or rally is equal to fifty activists in the Philippines holding the same placards at a mobilization in front of the U.S. embassy in the Philippines. For activists in the Philippines, it means a lot to them that their struggle and resistance is being highlighted by Filipino American activists in the U.S., "in the belly of the imperialist beast." As Max Santiago points out the importance of this connected struggle.

I think you have a very big part, cultural workers abroad, even in the belly of the beast, in the U.S. If the cultural workers abroad are effective in their ways, I think that also helps the movement here. Like if people there saw through your cultural work, "oh, that's what's happening over there in the Philippines," they realize we're not exactly disconnected. The struggle over here and the struggle in the states is really one big struggle together (Interview July 15, 2013). 


\section{Summary}

A common thread among the cultural workers in this study is that cultural work is defined as more than just the art created. It is a tactic in organizing populations that have been marginalized by the effects of imperialism, exposing and opposing the injustices of imperialism, and building a movement that therefore creates a culture of critique and resistance. For all cultural workers, the main role is that of organizer, and their art comes secondary, informed by struggles of the communities they are integrated in. They are more than just artists, they are ATORs_-Artist, Teacher, Organizer, Researcher. Another common thread is that cultural work in the National Democratic Movement of the Philippines extends beyond the borders of the Philippines, as Filipinos are a diasporic people forced out of their home country because of the social problems that plague it. The National Democratic Movement of the Philippines is one that engages in "counter hegemonic (trans)nationalism." For cultural workers in the U.S., their have the particular task of doing cultural work to advance the movement in U.S., the center of imperialist culture- "the belly of the beast."

\section{Research Question 2: How is cultural work used in the National Democratic Movement of the Philippines?}

When we discussed how cultural work is used in the movement, the cultural workers shared with me mainly their own personal experiences of being cultural workers, both the highlights and challenges. While organizing marginalized communities to join the movement, those who are directly oppressed and as well as those who are unaware of the injustices, there have been many victories as well as challenges. As discussed in Chapter II, the National Democratic Movement of the Philippines is a social movement 
that calls for the creation of a nationalist culture that is in direct opposition to colonialism, which is now in the form of imperialism. Creating a culture that is counter narrative to the dominant narrative of imperialist culture is not an easy task and is indeed a long-term process. In this process, many of the cultural workers have witnessed or experienced human rights violations, such as forced displacement, abduction, detainment, torture, and extrajudicial killings. They have survived to tell their stories and the stories of other survivors through their various forms of cultural work, as well as to advance the National Democratic Movement—all victories in and of themselves.

\section{Personal Experiences as Cultural Workers in the National Democratic Movement}

As stated previously, Axel Pinpin identifies himself as a peasant organizer and not a cultural worker, although he does not mind the label. What is most important to him is his organizing work with the peasants, and his cultural work through poetry is informed by their struggles. He has been writing poems since the age of four, being taught by his father. He began peasant organizing in 1999, though he did not share with the peasants that he was also a poet until much later. He did this because he wanted the peasants to see him primarily as an organizer and not just an artist. He shared his experiences of organizing peasants, as well as the struggles of the peasants themselves, to inform the poetry he writes. But a few experiences stand out, particularly his privilege of navigating between being part of an elite group of writers in the Philippines and being among those considered at the bottom of the social hierarchy — the peasants and farmers, and how being part of both led to his release after being illegally detained and facing trumped up charges of sowing terror.

I was part of an elite group of creative writers here in the Philippines, and I had that option of writing as a career, but it was already obvious that I'm a writer but I 
wanted to be more so involved in activist work. I can't be a poet just in my room, listening to Bob Dylan, The Night Watchman, or Tommy Morello, and be inspired. I need to be an activist on the ground everyday. I can't imagine doing just pieces if I'm not conscious of the struggles of the people. In 2006, I was becoming known for my writings and poetry right after I was illegally detained, and organizations and writing groups were clamoring for my release and surfacing of me and my fellow activists who were also detained. So, in the media, I was packaged as an activist-poet. After almost 20 months of detainment, I was released in 2008 and I was writing again with other writers, but this time we compiled a books of our writings with a more progressive and revolutionary theme, particularly about the peasant sector (Interview July 14, 2013).

Another experience Pinpin shared was how highly his poetry is regarded, both by the National Democratic Movement and mainstream critics. The irony about that is while his poetry is highly acclaimed by mainstream society in the Philippines, they are also quick to vilify him for his activism.

Modesty aside, the critics within the ND Movement, consider the poems I created - actually I don't want to say my poems, but the poems of the peopleexceed in aesthetic value, going as far as saying one poem can arouse, organize, and mobilize the masses. I have no formal background in writing poems, none. You can refer to the preface by Jose Maria Sison in my book, and what he said there is 'It is not true what Axel said that he doesn't know how to use rhyme, or how to use measures in the poems.' Honestly, I'm not conscious of using those. Critics outside of the movement have said the words I use are very deep in meaning, but that's not true. I use the words of the masses, which are not common to that crowd, so it just appears deep. But if the peasants read it, they know what I'm saying. That's what we need in involving the arts (Interview July 14, 2013).

What is important in what Pinpin shared is that he did not have any formal training in poetry, which is very common for many cultural workers. Some are fortunate to have formal training in whatever art form they use, and some do not have access to formal training and learned their craft on their own.

Like Pinpin, many of the cultural workers Boni Ilagan first began organizing with also did not have formal training. Currently a filmmaker with CAP as well as creative consultant for independent film production collectives Kodao Productions, Southern 
Tagalog Exposure, and SIPAT, Ilagan began his cultural work in the late 1960s as a theater artist. He was part of Kabataang Makabayan (KM), the youth and student organization that was very prominent during the First Quarter Storm. As discussed in Chapter II (p. 63), the First Quarter Storm was a period of massive protests against the Marcos regime that ultimately led to the declaration of Martial Law in 1972. Ilagan was asked by members of KM to start a cultural arm for the organization, given his previous experience as a member of the University of the Philippines' mobile theater group. He along with others with some formal training shared that with other members aspiring to do organizing through cultural work.

We didn't know anything about theater, and they all depended on me because I was a member of a theater group, little knowing that all I knew was how to act. I had to write the script and direct. After that initial attempt, we were joined by professional theater directors, one of whom was Leo Rimando, one of the pillars of theater in UP Los Banos. He was Western-trained, he knew the theories, and he was doing Broadway. The good thing is that he brought with him his knowledge of theater, plus a rediscovery that theater ought to serve the people, to serve the purposes of the movement. The other people's organizations also formed their own theater groups. So in no time at all, there were several other community based theater groups. There were groups also forming among writers, among visual artists. And so, by 1970-1971, we were a multidisciplinary cultural movement already, complementing the general people's movement. I think what really hastened our expertise was our direct work with the people. We did not bother about theories, we simply plunged into the work. So it was like learning warfare through warfare. Every time we had a production, we would assess, we would get the lessons, line up our learning points. Eventually we came up with our own theoretical framework. It was social practice that really made us competent in our specific line of work. We also employed what was called at that time 'panoorin ng masa,' or mass criticism. No work of art would pass without undergoing collective discussion among ourselves, then later on with our audiences (Interview August 2, 2013).

Like Boal's poetics of the oppressed, direct integration with the community contributed to the expertise of these cultural workers like Ilagan in their respective art forms, a 
practice which continues among cultural workers to this day. He did not directly mention Boal or Theater of the Oppressed, but his experiences have many similarities.

With the declaration of Martial Law in 1972, people's organizations like KM and the many cultural theater groups were considered illegal. Anyone critical of the government was considered an enemy of the state. Many were silenced by enforced disappearance, abduction, torture, and extrajudicial killing. Many activists were forced to operate underground, forming clandestine cells to continue organizing marginalized communities against the fascist government. Cultural workers, being the artists they are, had to be especially creative in continuing cultural work outside of the government's radar. Ilagan shared his experience of changing the ways he and his fellow activists did cultural work during Martial Law.

We did lightning plays - two or three members would go to a market, or a church plaza, wherever people converged. We would start a debate of sorts, so people assumed that we were engaged in some kind of debate about issues, little knowing that it was a part of our act. And then later on, some people in the crowd would join us. And so it would become a lively, spontaneous discussion of issues. Those were the times when we would do trial and error activities using theater forms. Eventually, we thought of forming a theater group that adhered to the rules propagated by the Martial Law regime, meaning to say registered with known people in leadership, and we formed a couple of such theater groups that were able to perform. We performed traditional plays. Later on we would infuse the traditional plays with current issues. Then later on, we were able to establish, when the situation became relaxed, theater groups in the universities, where we were able to put up historical plays, religious plays, using safe frameworks. Of course, eventually our audiences would realize that the plays, even if the plays were traditional or religious, actually had messages that were against Martial Law (Interview August 2, 2013).

The implementation of Martial Law did not stop the movement from growing and advancing. In fact, the campaign of Martial Law to brutally silence President Marcos' critics only added to the growth of the movement, leading to the end of the Marcos regime by the People Power Uprising in 1986. Ilagan witnessed this growth of the 
movement as a cultural worker, being instrumental in the formation of a national federation of cultural groups that complemented the larger National Democratic Movement. In this period up to the present, the movement was able to garner support from a broad spectrum of sectors, ranging from peasant communities in the rural areas to mainstream actors in the urban centers.

At one point in the cultural movement in the Philippines, we bloomed to such an extent that we were able to organize a national federation of cultural groups, meaning to say theater groups, visual artists, musicians, dancers. The group was called Bugkos. It's a Visayan term that means 'unite.' At one point, there were 600 member organizations. We would do productions coordinated nationwide. For example, when there was a campaign against the U.S. bases, every region had its own concert against the U.S. bases. This was the 1980s. We also would have cultural activists form the urban centers going to the rural areas to do mass work and productions. Now in present day, we have in addition the many video groups like Kodao and STX. So while we are able to maintain our activity in the traditional arts, we are also able to maximize the technology in the cultural field. We're able to come up with documentaries, and now with films that could be shown in the mainstream venues that are able to mobilize commercial actors (Interview August 2, 2013).

Ericson Acosta was part of the resurgence of the cultural work in the 1990s, a period when not just cultural work, but the National Democratic Movement as a whole, was recovering from several internal struggles in the early 1990s. One example of the internal struggles was the disillusionment from the lack of systemic change in the aftermath of the People Power Uprising, resulting in certain groups rejecting the National Democratic Movement and breaking away from it altogether. The National Democratic Movement was able to recover from this period of internal struggle, and ubiquitously, cultural work was at the forefront of this recovery. Acosta recalled this period as a pioneering member of the prominent cultural organization Alay Sining, as a college student at University of the Philippines (UP), Diliman. 
I was a part of a National Democratic cultural mass organization called Alay Sining, which we started in UP. During this time, cultural work was recovering from a period of somewhat a very low level of activity. This was around the early 1990's. The work of Alay Sining was important because its experience became a model that succeeding cultural organizations formed towards in several other universities and communities. In fact, Alay Sining and some other cultural organizations in other universities were the core that later on formed Karatula, an alliance of national democratic cultural organizations. With Alay Sining, the work was basically trying to revive the ND cultural scene on campus, and giving support to the mass movement in Metro Manila. It actually reached the trade union movement. Alay Sining was also very much ready every time there would be a cultural activity in the other sectors, like labor rallies for example. But on campus, the work was to organize students who had inclinations for the arts. Alay Sining was also involved in theoretical discussions, like revolutionary aesthetics. We would have regular DG's, or discussion groups, as with any other activist organization. But we innovated what we called DJ's, or discussion jammings, using music jamming to attract students to be part of our discussions on issues. We also produced theater plays. We called our productions craft paper productions. As in the concept of Aesthetics of Poverty, we basically used craft paper because it was the cheapest material we could get. Because of collective work and the merging of different ideas, we came up with our own style (Interview July 28, 2013).

Similar to the growth of the movement in the 1980s through the cultural formation of Bugkos during Ilagan's time, the resurgence of the movement in the 1990s through cultural work, particularly the national formation of Karatula, can be credited to the cultural workers like Acosta during his time.

Going back to the main role of cultural workers as organizers integrating with marginalized communities, Acosta continued on this task after his days with Alay Sining. He took his cultural work to the rural areas, particularly peasant communities, taking on the role of ATOR. Although Martial Law was dismantled with the People Power Uprising of 1986, not much has changed in the Philippines since then, as subsequent governments continued to criminalize opposition and activists, ruling the country under de facto martial law. Acosta faced this criminalization while doing peasant organizing in 
2011, being illegally detained and wrongly accused of possessing explosives. He shared

how he survived this ordeal through cultural work.

So I was arrested without warrant by the military, during the time when I was doing research on human rights in Samar. I was trying to consolidate data concerning human rights violations in that area, specifically the recent history of sustained militarization. So I was doing that when the soldiers arrested me, because I was carrying a laptop. In those parts, a laptop plus forest equals armed revolutionary. So they charged a trumped up case on me of illegal possession of explosives. I was brought into the Cabayug City Sub-Provincial Jail, where I was detained for two years. I was regularly harassed and threatened both physically and psychologically, not to mention they would also send death threats to my parents and visitors. I was pretty much restricted. But, like every other political prisoner, they extend their previous work from outside into the jail itself. I would hold education discussions with the inmates and literacy work, kasi madami hindi magbasa (because many could not read). To a certain extent, I was also able to organize the prisoners, especially for a campaign to raise the ration of food. Now with writing, I was very inspired writing inside prison, despite the difficult challenges, basically what misery is all about inside prison. It was really tough writing. But I really thought that would be a very big part of my struggle inside prison, because the writings would reach the people outside. It actually helped, because the Free Ericson Acosta committee would regularly post my works I was doing inside prison. It helped me also in strengthening myself ideologically and lifting my spirit. There was a time it was really difficult to write, like there were demons in my head. Nightmares even, dealing with that ordeal, especially torture. I actually requested, 'I won't be writing as often as you want me to. Just bring visitors, if they're allowed to bring a camera, and ask them to interview me.' Now Apollo [our mutual friend] was able to visit me and was allowed to bring in a camera. So he started recording, and that was the first time I felt really ok, because I felt anger when narrating things, talking about the experience, and also trying to be optimistic. It was an overwhelming feeling of revolutionary optimism and righteousness that overcame me (Interview July 28, 2013).

The video interview with Apollo Victoria, a cultural worker in Habi Arts in Los Angeles, CA, along with Acosta's writings while in prison, were posted on the Free Ericson Acosta website and helped to garner international support not just for his release, but for the release of all political prisoners. These forms of cultural work, along with the organizing efforts of all those involved in the campaign, ultimately led to his release, very similar to Axel Pinpin's experience as a political prisoner. 
The number one thing that led to my release was a very sustained and broad campaign. It happened that I also had friends before who were artists not in the ND movement, also in media, who also clamored for my release. It was the effort of the Free Ericson Acosta campaign that actually made the case quite high profile, which of course led to other human rights groups from other countries noticing my case, like Amnesty International. It also helped that I was also writing inside, so I was able to communicate to the people outside. Sometimes I feel guilty about it, but of course I shouldn't. It's just that most of the political prisoners do not have that kind of support, or there's not many individual campaigns for individual political prisoners. While two years was hell, definitely, it's really short compared to the other political prisoners. But the thing was, while the Free Ericson Acosta campaign was doing its thing, it was also carrying the campaign to free all political prisoners. It gave enough pressure to the agencies concerned to finally work on my case and finally dismiss my charges (Interview July 28, 2013).

While many cultural workers have witnessed or even directly experience human rights violations at the hands of the Philippine government, there were some that did not face similar criminalization by the government for their cultural work. One particular group of cultural workers were those privileged enough to be mainstream artists. Pendong Aban, Jr., member of the legendary Filipino folk rock band Asin, is one such cultural worker. Perhaps it was because their music resonated with all Filipinos, both the oppressed and ironically those in power, despite their music speaking to the harsh realities of injustices in the Philippines. Or perhaps it was because of their privilege as popular mainstream artists, as many regarded them as the Beatles of the Philippines. Regardless of who loved their music, Asin and their music always sided with the oppressed sectors of society, and members were often found performing at mobilizations and rallies for various social justice campaigns. Aban, Jr. shared his experience as this particular kind of cultural worker.

In the 1970s, in the Philippines, American folk singers were famous-like James Taylor, Bob Dylan, and Peter, Paul \& Mary. When I was in Asin, we started with the idea of also doing folk rock songs in Tagalog and about the realities happening around us. We did the song Masdan Mo Ang Kapaligiran (Behold the 
Environment), and we were surprised that we were suddenly famous because it was an immediate hit. So we played in concerts around the Philippines, and around that time in the late 1970s, there was war going on in Mindanao. So I'm from Mindanao, and Saro Banares, Jr. - the one who composed Balita (News) and Masdan Mo Ang Kapaligiran, was also from Mindanao, and we saw these atrocities and injustices along the road, so that's what inspired these songs. During Martial Law, only one of our songs was censored, Ang Bayan Kong Sinilangan sa Timog Cotabato (My Birthplace, South Cotabato) because there's some words there, 'Kapwa Pilipino ay papatayan' (We're killing our fellow Filipinos). The government didn't like that, because they kept secret of what's happening in Cotabato, Mindanano. So instead of that, we said 'Kapwa Pilipino, bakit pinahirapan mo?' (Fellow Filipinos, why torture each other?). That's the only sentence, the government didn't really know the rest of the songs. We also sang Magnanakaw (Thievery) and other songs like that, but we didn't say 'the Marcoses are thieves,' we weren't being confrontational. We sang that song like thievery is a cancerous habit for Filipinos. We weren't idle about that. But it just so happened that at the time, President Marcos had his birthday celebration in Laoag, in Batac. All the artists of Vicor Records were invited to go there, so we played. We played Ang Bayan Kong Sinilangan sa Timog Cotabato, and there were a lot of military there. The beauty of the music of Asin is the military also liked it, because it's natural and true. There's a lot of stories of war at that time. So they requested it, and we sang it in front of them at the party! So, we didn't face harassment as Asin. After Asin, I formed Ang Grupong Pendong, which was very active in the streets, during the time of anti-U.S. bases sentiments, like 'Yankees, go home!' One time we had a long caravan to Subic from Manila. Everybody was there, the BAYAN organizations. Since it was a caravan, we would go to the each town along the way and rally and play our music. This was all in the early 1980s. I wasn't really an organizer then. I did a few workshops with other artists for peasant communities in the provinces, but I mostly was just a musician, supportive of the people's movement (Interview December 12, 2013).

Now based in the U.S., Aban, Jr. still continues to compose music, though not at the same "rock star status" he had in the Philippines. He lives a humble life in Daly City, CA with his wife Chat Aban, a part-time instructor in Philippine Culture and Music at UC Berkeley and also a cultural worker, as a singer in Ang Grupong Pendong. They currently organize with Committee for the Protection of Workers' Rights (CPWR), a recently formed workers' rights organization comprised mostly of Filipino cultural workers who recently migrated from the Philippines and who want to continue organizing work. Their organizing with workers, particularly migrant workers, informs the music 
Aban, Jr. currently composes. They frequently collaborate with Joi Barrios-Leblanc in producing cultural work, most recently in Barrios-Leblanc's Piketlayn Cantata, a musical about the plight of the workers and peasants, sung entirely in Tagalog. Aban, Jr. shared doing this musical was special to him because he identifies with the working class.

In Philippine culture, if you're a worker or a peasant, you are at the bottom of society, like in the song Tatsulok (social pyramid) by Noel Cabangon. That's why we do songs like that, because society is cruel and discriminatory. I don't like the injustices, especially in labor. My wife is still working, my son also works at Target. My father was also a worker, so that's why I have a sympathy for the workers and peasants. Besides that, when I was 15, I worked as a laborer constructing the road. So it is in my heart, labor is no joke. They should be given the right wages, people's rights, like that (Interview December 12, 2013).

To this day, the music of Asin remains popular with Filipinos, both in the Philippines and abroad, attesting to the transnational reach and impact of cultural work. Their music is still used extensively at rallies and mobilizations. One particular song, Balita, gained broad international exposure when rapper Apl.D.Ap (real name Allan Pineda Lindo), member of the internationally acclaimed Hiphop group Black Eyed Peas, included the chorus of Balita in his song The Apl Song, which talks about his life growing up poor in the Philippines and migrating to the U.S.

Balita again became popular in 2013 when it was sung by a contestant on the music competition show The Voice of the Philippines, which is a counterpart of The Voice television series, similar to music competition shows American Idol and X Factor. The contestant, Darryl Shy, intentionally sang Balita on the show during the Pork Barrel corruption scandal in September 2013, in which billions of Philippine pesos were revealed to be illegally funneled from the taxpaying citizens into corrupt politicians' coffers, called pork barrels, through bogus projects and charities, the largest pork barrel belonging to President Aquino. This scandal caused massive outrage among the public, 
even mainstream Philippine celebrities, as well as among Filipinos abroad who became increasingly concerned that portions of their hard earned remittances were being funneled into pork barrels through corrupt practices. Millions of Filipinos in the Philippines and abroad took to the streets to express their outrage at this scandalous corruption of public funds. Although Shy did not win the competition, he was highly praised by the Filipino people as well as the show's celebrity judges - which coincidentally included Apl.D.Ap, for singing Balita during what they viewed as a very appropriate time. Shortly after the show, Shy joined the movement in the streets protesting the Pork Barrel scandal, singing alongside cultural workers various protest songs, including Balita. Aban, Jr. shared how happy he is that the music he made with Asin is still being used in the movement, especially during such a relevant time.

I'm happy that Apl.D.Ap picked up our song Balita, because for me that song is not only for the Philippines. It's for the whole world, because there's a lot of countries now going through chaos. I'm happy that we contributed to other visions, other aspects, through songs that expressed our sentiments. I'm also happy because I know the guy who competed on The Voice of the Philippines, Darryl Shy, and he sang Balita in that show. We're friends, actually! Because he's an artist also, he's a folk singer, and so we have many mutual friends. So I'm happy he reached that far, so close to winning the contest. But I'm happy for him, because he's a good person also. And I heard he's now active in the rallies, in the people's movement (Interview December 12, 2013).

The music of Asin is one example of how music is a form of cultural work that has been used to garner broad support for the National Democratic Movement of the Philippines. Their music remains popular because it is very accessible and resonates deeply with people.

Another form of music that has been used by cultural workers to raise the social consciousness of marginalized communities they serve and garner their support for the movement is Hiphop, as mentioned earlier. For Mario "Nomi” Demira, frontman of the 
Hiphop group Power Struggle, Hiphop was instrumental in not only his politicization, but also for him in politicizing youth and workers. Formerly of the independent Hiphop group Odd Jobs, Demira started to become politicized when he moved to the San Francisco Bay Area from New York in 2004, after Odd Jobs had disbanded. He shared the moment that sparked his political consciousness and began his journey as a cultural worker.

I remember I went to the Philippines in November 2004 for a family reunion. Even for most people that are just slightly aware of things, just the trip to the Philippines itself, even if it's a vacation, it can affect you. When I came back after that trip, the Hacienda Luisita Massacre happened, and I remember like, 'damn, I was just in the Philippines.' I found out about Hacienda Luisita not through the news, but through a show at Bindlestiff. The Filipino American punk band, Eskapo, was playing there, and I used to be a big punk fan, and I still am. They had some raw footage of the massacre, and they were trying to propagate the information about what happened. I had never seen anything so outrageous. I was so shocked by what happened at Hacienda Luisita, and from that point on, I wanted to get involved and learn more. That just sparked my hunger to learn more about the Philippines and what's happening there, which eventually got me hip to the ND movement. So that was a big catalyst moment, and from that point I started getting involved (Interview November 4, 2013).

Through the cultural work at Bindlestiff, a Filipino American theater space located in the South of Market Area (SOMA) of San Francisco, Demira began wanting to use his music as a rapper for political change, as well as getting involved in community organizing. He participated in what was known back then as TIBAKs (Tagalog slang for activist), a series of Filipino political education workshops, similar to Ericson Acosta's experience doing DGs. He along with fellow Fil-Am rapper Kiwi and Anthony "Pele” Navarro, a youth organizer at the Filipino Community Center (FCC), took what was learned at the TIBAKs and developed the Hiphop Workshop in 2007, as a project of Active Leadership to Advance the Youth (ALAY), a broad grassroots Filipino youth organization. The first batch of participants in the workshop were mostly local youth of Filipino descent, both 
American born and recent migrants. The Hiphop Workshop met once a week to discuss community struggles, locally and in the Philippines, and then compose songs that reflected those struggles. This culminated into a compilation CD. Demira saw the Hiphop Workshop as one of those special moments that helped politicize the youth, and many of them went on to become organizers themselves in the National Democratic Movement.

That was really dope to be part of, and utilize something that you really love, like Hiphop music and culture. That's when I realized the power of art. I don't think I ever thought about art in terms of being able to move people, especially to actually change things in our society. A few of the youth in the Hiphop workshop went to college, majority joined the workforce as entry level working class, some became more engaged in organizing in the ND movement, and some of them are leading their own organizations now. Some even became full-time ALAY members and are leading the organization now (Interview November 4, 2013).

As Demira was getting older, he transitioned away from youth organizing, being that most of the campaigns ALAY was taking up were school-based, and the age gap between the youth and him was getting wider over the years. Demira graduated high school in 1997, and immediately joined the workforce, so he felt like he could not relate as closely to school-based issues because was the type of student who hated school, but liked learning. Joining the workforce at an early age, he felt he identified more as a worker, which led him to transition into workers organizing, particularly migrant workers. As a migrant himself, his migration story and eventual organizing is an example of widening the circle of transnationalism. He closely identifies with migrant workers, being a Filipino born in Nigeria to parents who were Filipino OFWs based there, and moving a lot throughout his life.

I already considered myself more of a worker, because I was working full time and the jobs that I did were mostly manual labor work. I was a picture framer, I worked in light manufacturing, I did deliveries for a car company, you name it. Around 2009, I got the opportunity to work at the FCC, working on the workers' rights program. But in terms of organizing, I kind of just leaped over and started 
doing migrant worker organizing through the FCC. We have a workers' rights program, where we do advocacy and education, outreach to Filipino migrant workers to educate them on their basic rights. That really was another point that shifted my perspective, and put me in a direction where I wanted to go in terms of my life's work, and even my cultural work. Through our work at the FCC, we partnered with some representatives from Gab-USA, NAFCON, and a couple of professors - Dr. Valerie Francisco of USF and Dr. Robyn Rodriguez of UC Davis, to do a research project, called the CARE Project, on the conditions of migrant workers, particularly around Filipino caregivers. This began in early 2012. After we did this research project, the workers decided to form their own organization to propagate their work. So they formed Migrante-SF, an overseas chapter of Migrante International in the Philippines, which is an ND Filipino migrant workers' organization. My role since then has been helping their members and officers run the organization (Interview November 4, 2013).

I was privileged to be part of the CARE Project alongside Demira and all those involved. I remember much of what we did with the Filipino caregivers to help them articulate their struggles was not through dense discussions, but through cultural work, particularly the creative exercises of Boal's Theater of the Oppressed. It was amazing to see the Filipino caregivers share their narratives through theater, song, and dance. Most of them were not comfortable expressing themselves verbally, but Filipinos being natural performers, as history has shown, it was much easier and fun for them to express themselves through cultural work. It was one of those moments that revealed the significance of cultural work as an organizing tactic and raising political consciousness.

Demira continues migrant workers organizing with Migrante-SF, as well as cultural work as a rapper in Power Struggle. Though not necessarily using Hiphop to organize like he did with youth, because the migrant workers he organizes with do not listen to Hiphop, what is more important to him is how their experiences as migrant workers inform his cultural work.

Because I am a Hiphop artist, I think there is somewhat of a disconnect between Hiphop music and migrant workers. Not a lot of them are really into Hiphop. But I can use my experience as an artist to creatively capture their stories. It's more 
about what migrant worker organizing has done for my music. Just spending time with Filipino migrants has really given me a broader view on the condition of Filipinos, not just in the U.S., but internationally. What I'm trying to do is put those stories into the music that I create now, so I can propagate the story of migrants using the genre that's more accessible for young people, and to hopefully encourage them to be educated about what's happening with Filipino migrants, the struggles they face, and the reasons why our people are basically shipped abroad to work (Interview November 4, 2013).

Elaine Villasper-Dizon is another cultural worker whose art is strongly reflective

of the communities she has integrated and organized with, both in the Philippines and the

U.S. It was through her politicization during her college days through community

organizing that helped her come to terms with her identity as a former undocumented

Filipino immigrant who felt she was constantly bombarded by U.S. mainstream culture to hide, or be ashamed, of her Filipino culture. Her involvement with the Pilipino American Collegiate Endeavor (PACE) at San Francisco State University helped spark her political consciousness and eventual entry into the National Democratic Movement of the Philippines.

When I joined PACE in college, that was the first time I had heard people talk about Filipinos. By college I had gotten so far away from Filipino identity or culture. A lot of classmates in high school were also Fil-Am, but very few Filipino immigrants. But over the course of all those years, we stop talking Tagalog and really just tried to assimilate to American culture. The extent of Filipino identity for us were just things like eating Adobo and dancing Tinikling. So by the time I got to college, I was just really surprised that there were people who wanted to be Filipino and talk about other things about being Filipino aside from the food or dances. I was exposed to issues like the Filipino World War II Veterans, and sex trafficking. That was really the beginning for me. The turning point was when I started to learn with folks who were in LFS, though I was never a member. I met a lot of friends in LFS through our collaborations in PACE, and this was before BAYAN-USA was created. At that time I felt like my whole being was attacked. It was around the Sensenbrenner Bill, anti-war in Iraq era, around post-9/11. It was through the movement that I started to realize that the hardships that we faced weren't because we were bad people, or that we deserved it. It was the first time I heard a narrative that said there's something at play, and it's not your fault that your life is like that. That's really what made me come closer to organizing and movement work (Interview November 7, 2013). 
Villasper-Dizon soon enough became deeply involved in the National Democratic Movement after graduating college, when she and her fellow recent college graduates wanted to continue activism that was strongly connected to the struggles in the Philippines, particularly women's struggles. She and her group of women activists saw the importance of continuing activism beyond college, and not just as a passing phase in their lives.

After PACE, I was recruited to build babae! At the time we didn't have a name for it. It was basically just a bunch of women, post-college, graduated from LFS, graduated from school, and wanting to continue organizing work but they're not youth anymore. So a couple other women from PACE and myself started doing women's studies together. Afterwards we decided to launch babae [now known as Gabriela-SF]. At the time a lot of it was education around Filipino women's issues. The big campaign we were taking up was domestic violence. It was a hot topic San Francisco back then because a woman named Claire-Joyce Tempongko was murdered by her partner, even though she had done everything in terms of seeking support. We were also helping to build FCC at the time, so we were also doing needs assessments in the community. I was officially a member of babae for five years. Beyond babae, when BAYAN-USA was formed, we started to take on the work beyond the reach of the local level and connect with other women's groups in the other areas, as the pre-building of Gabriela USA. That was like 2008-2009. So towards that time I started to transition from local babae work focus on the building of Gabriela-USA, which is Filipino women's alliance that advocates for women's issues and connecting women's issues in the U.S. with women's issues in the Philippines (Interview November 7, 2013).

In terms of cultural work, Villasper-Dizon did not become a cultural worker, or identify as such, until years later of community organizing. Becoming a cultural worker was a result of her first basic mass integration in the Philippines in 2008 through the Filipino women's organization Gabriela, as she needed an outlet to process all she had learned and experienced in her integration with the peasant and indigenous communities. That outlet was painting and other forms of visual arts, which she continues today as her form of cultural work. 
In 2008, I went on a 6-week integration, and what really captured me during that expo was when we went to the Cordilleras and lived in a very remote community for two weeks. It really made me see the world in a different way, and really understand the ways that culture in the U.S. had polluted everything. So when I got back to the U.S., I was really sad, I didn't want to be here, and I was really longing for the Cordilleras - the mountains and people, just the simple way of life. In the mountains, you don't have electricity or running water, but I felt so fulfilled there because the most important aspects of life were present. And I come here, and I have everything my parents ever wished for me when we migrated - a good home, job, partner, and a lot of nice material things, but I felt like life here was so empty. I was really looking for an outlet to release the things I was feeling. So I took a beginner's painting class, and I didn't know I could paint! So for the first six months, I was only painting about the Philippines, the Cordilleras, like that kid [points at one of her paintings], that's an actual kid from the Cordis, his name is Pog-Pot. That was one of the first paintings that I did. Over the years, I've come to have a deeper grasp of what it is that I want to create. I'm able to articulate that more now than I was before (Interview November 7, 2013).

What eventually came out of her years of growth as a cultural worker is her current project, Kulay Kalayaan (Color of Freedom), a Facebook page that showcases her art, as well as making available for purchase at reasonable prices, as she wants her art to be accessible. Much of her current art is of happy and kid-friendly images coupled with messages of struggle and resistance. This is inspired by her experiences as an activist, and also as a new mother. Some examples are colorful Tagalog alphabet flashcards, a calendar that features her artistic depictions of Filipino activists and revolutionaries for each month, and baby clothes imprinted with the words, "My Mommy's Place is in the Struggle," a nod to African-American activist Assata Shakur's words, “A woman's place is in the struggle."

What will be discussed in the next section is some of the highlights of cultural work in the National Democratic Movement, as told by the cultural workers themselves. 


\section{Highlights of Cultural Work in the National Democratic Movement}

One of the highlights of cultural work in the National Democratic Movement of the Philippines was the release of the independent full-length feature film, Dukot (Abduction), in 2009. Boni Ilagan wrote the film's screenplay and helped direct it with Joel Lamangan, one of the more famous film directors in the Philippines. This film was produced during the regime of President Gloria Macapagal-Arroyo, an era of rampant human rights violations. The main form of human rights violations depicted in the film was enforced disappearances of activists by elements of the Philippine military, and the story is loosely based on the stories of enforced disappearances of activists Jonas Burgos and Melissa Roxas. This film featured well-known mainstream Filipino actors and actresses, who knew very little of human rights violations prior to the film. Ilagan shared the struggles, triumphs, and importance of making the film, not just as a cultural worker in the National Democratic Movement, but for the awareness of all audiences about the human rights crisis in the Philippines.

Joel Lamangan, one of the more popular film directors in the Philippines, was an activist in 1960s and 1970s. He was also a political prisoner, twice imprisoned and tortured. Joel and I thought of doing a film on human rights, but we knew it was easier said than done. For one thing, a film on human rights couldn't be a commercial venture, and no producer would invest in a film like that. But Joel said, 'We have to do it now, or we won't be able to do it.' He was able to salestalk a novice producer into investing in the film. Joel, being a popular director, found it not difficult to assemble a crew and cast for our human rights film. But the bigger problem was submitting it to the MTRCB, the Movie \& Television Regulatory Classification Board. It was given an X-rating, and could not be shown publicly. Their reason was because it incited the people to sedition and rebellion. And Joel replied, 'Please show me one sequence in the movie that asks the people to rise up in arms against the government.' And they could not pinpoint any sequence. Finally, it was given an R-18, good enough. But in the Philippines, if it's R-18, it could not be shown in the chain of commercial cinema houses. But we had a very short run in about eight commercial cinema houses, which didn't earn much. Of course, in the first place, Dukot is not a feel good movie that people would pay P150 to watch. And so we thought we should really 
tap into the alternative circuit - the campuses, parishes, and people's organizations. It was warmly received, the venues were packed. But that is not to say the film has been earning, because in the first place, we could not sell our tickets for P150. Our audiences were the masa (masses) - students, workers, peasants; and they could not afford P150. So we really had to reduce prices. While we had big audiences in the Philippines, the earning was not much, and that displeased our producer. After that, we did rounds in our networks abroad. We've been to Canada, Hong Kong, Taiwan, Japan, the U.S., and Europe. So to make a long story short, I realized that doing a film on human rights is one story. Marketing is an entirely different story (Interview August 2, 2013).

What was more important about the film Dukot was not the revenue it would earn, or in this case not earn, but the intention to make the film accessible to the public and highlight the human rights violations in the Philippines. The topic of human rights is virtually non-existent in Philippine mainstream media, meaning to say not reflected in television shows or movies. What was also significant was the participation of wellknown Filipino actors and actresses in the film, such as Allen Dizon, Iza Calzado, and Gina Alajar. Though not commercially successful in terms of revenue, the critical acclaim of Dukot led to other independent films by Ilagan and Lamangan with similar political themes, such as Sigwa in 2010, Deadline in 2011, Migrante in 2012, and Burgos in 2013. The participation of well-known Filipino actors and actresses increased in these films since Dukot, such as Zsa Zsa Padilla, Jodi Sta. Maria, Bangs Garcia, Dawn Zulueta, and Tirso Cruz, III, just to name a few. Despite the low pay these actors and actresses would be earning by doing these films, Ilagan shared they participated anyway not just because of their desire to work with a film director as accomplished and reputable as Joel Lamangan, but also of the importance of doing such films in raising the awareness of the ills of society. Having these famous actors and actresses in these films was in a way its own marketing, because they are very popular among Filipinos. This goes back to what 
Axel Pinpin mentioned as ways of using cultural work to penetrate the mainstream and popularize the movement.

Along the line of film as a form of cultural work used to popularize the National Democratic Movement, another form is music, as previously discussed with Pendong Aban, Jr. One of the forms of music that has been becoming more prominent in the National Democratic Movement is Hiphop, and as in any urban center in the world, it is very popular among the urban youth in the Philippines. As Axel Pinpin mentioned previously of the music of Filipino American rapper Kiwi being used by the youth of the peasant communities he organizes with, Mario "Nomi" Demira continues the popularization of the National Democratic Movement through Hiphop. His latest albums Remittances and In Your Hands reflects the everyday struggles of oppressed populations, mainly drawing from his experiences of organizing with youth and migrant workers both in the Philippines and the U.S. These albums, produced in collaboration with other cultural workers who are also rappers and Hiphop producers, are Demira's personal highlights as a cultural worker, sharing his personal growth in the National Democratic Movement and making music that not only has a strong message, but is also of high quality in terms of aesthetics.

I'm most proud of being able to capture the stories of our folks, through our analysis - the ND analysis, in a record. And I'm going to brag, that in terms of our production, our sound quality, our beats and all that, we put a lot of work into our music so that we put out the best quality. We put a lot of work into trying to make good art at the same time. We're not just all about the message, we're trying to make good aesthetics. So I'm proud of the fact - in the line of the [Filipino American rappers] Rocky Riveras, the Bambus, the Blue Scholars, the Kiwis; I'm proud that we all make this music that says so much and is really deep in the amount of information and knowledge on issues, but that it's also well made. A lot of people say I'm my harshest critic, but everything I used to put out before the album Remittances, I thought was fucking garbage. I was like, 'How did we get on a label? These songs suck!' But I guess we [Odd Jobs] had appeal or 
something. With Remittances, I was little more like, 'Yeah, this is solid,' but with this upcoming release In Your Hands, this is the first time where I'm like, 'This really means a lot.' It also makes me feel content, to an extent where if, God forbid, some shit happens where I leave this world, that I have this piece that really reflects my values, and obviously the values and analysis of the ND movement (Interview November 4, 2013).

Continuing the discussion of the use of cultural work to popularize the movement to a broad audience, visual arts is used extensively. Not to say that other forms of cultural work are less significant, but visual arts is important to highlight because despite access to public education, there is still a significant population who are still lacking in literacy. This is where visual arts play a significant role, because though some populations may be illiterate, they are able to understand the message and learn of social issues and struggles though visual arts. This is especially true in the Philippines, in which about $70 \%$ of the national population are peasants and workers, two sectors that lack the resources to higher education.

A major highlight in the National Democratic Movement of the Philippines is the annual SONA ng Bayan, or People's State of the Nation Address. This annual event is a large-scale protest of tens of thousands of people in the National Capital Region, led by National Democratic mass organizations, against the Philippine president's State of the Nation Address, which the government uses to paint a rosy picture of progress and development in the Philippines. Activists have come to refer to the president's annual state of the nation address as just a "litany of lies." The SONA ng Bayan, or SONA for short, reveals the true state of the nation, highlighting social issues like massive poverty, joblessness, landlessness, forced migration, government corruption, and rampant human rights violations, all of which according to the National Democratic Movement are rooted in the three basic problems of imperialism, feudalism, and bureaucrat capitalism. SONA 
is also internationally coordinated, as National Democratic mass organizations hold their own SONA in front of Philippine consulates and embassies all over the world.

At the forefront of the SONA is cultural work, especially visual arts like street murals and effigies. The cultural collective Ugat Lahi has been making effigies of Philippine presidents since the Estrada regime in the late 1990s, and has since become synonymous with the SONA. The effigies are large paper mache depictions of the Philippine presidents, depending on whose presidential term it is at the time. The effigies are carried along the march of the SONA, and at a certain point in the program are burned to the ground to express the people's outrage at the government. Max Santiago of Ugat Lahi shared his experience of making effigies for the SONA, which in the process of making them are teaching opportunities for volunteers, mostly students and international exposurists doing basic mass integrations, about the social conditions of the Philippines.

Ugat Lahi has been doing the effigies since the late 1990s, during the time of Joseph Estrada. It continued through the time of Gloria Macapagal Arroyo, and actually that's the longest time we've been doing effigies targeted at a specific Philippine president, the nine years she' been in power, different effigy variations of her. There was a progression, the effigies of her got uglier and uglier with each passing year. The first effigy of [current president] Noynoy Aquino in 2010 wasn't quite as ugly, which was of him as a magician, because he didn't lay out his plans yet at the time. But as time progressed, we saw the different effigy variations of Noynoy. In 2011, we made Noynoy as a penoy (duck egg), like Humpty-Dumpty falling off the wall. 2012, him as a two-faced liar, and this year of 2013, we're making him as a ugly giant feasting at a table while the people wait for crumbs at the bottom (Interview July 15, 2013).

The first effigy of President Aquino that Santiago described was not burned to the ground in the SONA of that year, because he was just elected two months prior and did not have the time yet to lay out his platform. This was also because he was popular at the time of his election, being the son of Senator Benigno Aquino, Jr., who was assassinated during Martial Law for being very vocal in opposing President Marcos. Also in context to his 
initial popularity, Noynoy's mother, former president Corazon Aquino, had passed away just nine months prior to the election. Corazon Aquino was catapulted by the people into the presidency after the People Power Uprising of 1986 toppled the much hated Marcos dictatorship, adding much to the sentimentality of the Filipino people towards Noynoy. Though starting out as popular, Noynoy Aquino showed he is no different from previous brutal regimes with each passing year by continuing the anti-people policies and human rights violations. Because of these, his popularity dramatically waned, and the people resumed burning effigies of Noynoy at the SONA after his first year of presidency.

Visual arts continue to be used as a form of cultural work to popularize the movement and to highlight all forms of struggle. For Villasper-Dizon, the highlight of cultural work was being part of a collectively curated art gallery in the Oakland, CA, that highlighted revolutionary struggle in the Philippines. This was meaningful for her to be part of, because at the time, she had just started painting, and other cultural workers who had years of experience in visual arts saw the value in her art that they wanted to include her cultural work in this gallery.

That just blew my mind. I didn't even think that I was any good, or that I could make anything relevant to feel like I was worthy of being in a gallery. But I was really proud to have been a part of that that gallery. It was such a diverse group of artists that were part of it, and also I felt at home in the politics they were projecting - talking about the revolutionary movement in the Philippines, and having different forms of artwork that were connected to and celebrating the revolutionary movement of the Philippines, and especially an aspect of the revolutionary movement that doesn't always get talked out, which is armed struggle. But for me it's still a very valid, very beautiful kind of struggle too. So it was nice to be able to contribute to that, also as a very young and new artist. I felt at home and very privileged to be among some of the people that were asked to contribute. Some of the artists who were also part of that were Sergio RobledoMaderazo, some folks from Habi Arts also, there were artworks from the Philippines they had also enlarged, artwork from Kaparts Bagani, those were some of the folks I have been looking up to when I was learning and finding my way in art (Interview November 7, 2013). 
I remember going to this gallery with one of my co-workers at the time, who I invited because he likes to draw comic book superheroes as a hobby. I remember him being amazed at the artwork presented learning about the decades long people's resistance and freedom fighters in the Philippines, which he did not know existed. Since then, I noticed that he encouraged the children he works with to draw pictures about their own personal freedom fighters in their lives and what makes them proud of their cultures, not just duplicate Disney characters or other cartoons. Through the cultural work in this gallery, he became aware of the movement and has been supportive ever since.

For Joi Barrios-Leblanc, a major highlight in cultural in the National Democratic Movement was not necessarily the cultural work itself. She has been a cultural worker in the movement for over thirty years, and has produced many works as a poet and street theater actress, so she has much to be proud of in producing cultural work extensively. But for her, the highlight was the actual organizing of cultural organizations on a national level that included a broad spectrum of cultural workers, ranging from humble community artists to professional mainstream artists. She mentioned how this formation was significant in popularizing the movement and its immense growth, as previously discussed by Ilagan with the formation of Bugkos and Acosta with the formation of Alay Sining.

This was the time of the forming of what we called the National Cultural Movement. Bugkos was national at that time, around 1986 or 1987. This was towards really uniting all organizations. So when I was there with Bugkos, I was chair of the alliance of youth theater groups in Metro Manila, or ALAMAT. What happened was, and I remember that founding congress very well, there was someone who talked about the theater scene among the professionals and I talked about the theater scene as far as the student and youth groups were concerned, and we came together to form ALAMAT. That was one of the achievements that we're so proud of! You also have to remember that this time, in the early 1980's, 
that CAP was formed, in an effort also to organize professional artists, especially those working in the film industry. So we would have the big names, like Lino Brocka and Ishmael Bernal. CAP continues to be active now, although with less big names as members (Interview December 7, 2013).

These organizational formations reinforce what all cultural workers agree onthat the main task is organizing and art being the secondary task. Marconi Calindas took this role of organizer seriously, as a cultural worker in Theatro Umalohokan at University of the Philippines, Los Banos, in the mid-1990s. For him, being fully integrated in the communities with very limited resources and doing cultural work with them was very rewarding not just for him, but for the movement as a whole.

One high point was we immersed in the small towns in the provinces. We held visual arts and theater arts workshops with impoverished kids. For me, I'm a firm believer that cultural work is more effective in conveying messages, especially if you want to get through to the masses. Historically speaking, cultural work has played a huge part in disseminating information to the masses. So if we actually let them hear songs, see art, and watch a play, they actually get the message through art forms, more than just telling them what to do. So connecting that to the ND struggle, we use that as a vehicle for organizing. It was amazing to see the kids happy, that they can actually hold paints and colors, and do theater. We saw their faces light up, that they're finally getting an art lesson and theater in their community - and these are the communities that are underserved by the Philippine government. We of course imparted theater with a message, not just 'art for art's sake' (Interview December 7, 2013).

Along with the highlights of the Nation Democratic Movement comes its challenges, and cultural workers have had their fair share of facing challenges. The next section will discuss the challenges cultural workers face, both external and internal to the movement.

\section{Challenges of Cultural Work in the National Democratic Movement}

As discussed in Chapter II, social movements are long-term processes (p. 53).

This social movement has been in existence since the Philippine Revolution of 1896, and 
while there have been many victories and advancements towards national democracy, there have also been challenges, some taking years to overcome.

One of the main external challenges in the National Democratic Movement is challenging the hegemony of dominant mainstream U.S. imperialist culture. Changing centuries of colonization and imperialism, and fighting to create the culture and society we would want for ourselves, is not an easy task. As with building and maintaining a social movement, the process of decolonization is a long-term struggle. Decolonization is a process of "re-membering" a culture that has been literally and figuratively dismembered, a painful process of a "putting together of the dismembered past to make sense of the trauma of the present" (Bhaba). U.S. imperialist culture has ingrained into Filipinos in the Philippines and the diaspora a culture that is not theirs, nor will it ever be. Cultural work seeks to not only "re-member" the cultural dismemberment caused by imperialism, but to combat it directly to create a culture that is truly reflective of the people. One of the ways to accomplish that is, as Axel Pinpin described earlier, penetrate mainstream media and popularize the movement. This, of course, is not an easy task for cultural workers because aside from U.S. imperialist culture having a wide and powerful media reach, it also actively spreads black propaganda about the National Democratic Movement.

The number one challenge for cultural workers is actively combatting the other side, because their influence is very strong, the mainstream bourgeois culture. They have direct attempts to say that the arts in the ND Movement is stereotypical irrelevant activist shit, to put it bluntly. They always say 'Are you waging a revolution with these poems?' Of course! Like Mao Zedong said, 'The revolution cannot be waged forever without art.' That's inspiring, for a revolution. It's still inspiring now, the arts, which it should be for artists (Interview July 14, 2013). 
Resonating with Pinpin, Julie Po also shared that the biggest challenge for cultural workers is challenging mainstream media, which propagates U.S. imperialist culture. That culture has a very strong presence in the Philippines, which although is an independent country on paper, operates as a neo-colony of the U.S. It is evident everywhere in Philippine mainstream media. Most of the movies have English titles and their scripts are more in English than Filipino, most of the songs by mainstream Filipino artists are covers of American pop songs, and American films are more commercially successful than Filipino films. So to challenge such a strong presence is a huge challenge for cultural workers in the National Democratic Movement.

The biggest challenge is how to challenge midstream media, because they can spread their reach very wide. We have products, but how to deliver them to the people, that is our greatest challenge - to challenge mainstream culture, particularly through media. Of course, if we go back to what was mentioned before with the main task of cultural workers being organizers, that is the main challenge because you organize people who are so used to mainstream culturelike 'if you graduate, you should be an OFW and earn more, etc.,' or 'if you're an artist, you should follow the trends so you will be acceptable.' I think that's the challenge, how to organize people who have that kind of culture, the mainstream culture. Even the basic sectors, based on our class analysis, culturally they have been ingrained with the bourgeois culture (Interview July 1, 2013).

Another challenge for cultural workers, as with any activist, is livelihood-how to sustain one's self and the cultural work they produce. Being a cultural worker is not as glamorous as being a mainstream artist, as described by Boni Ilagan in his experience of doing a film like Dukot. Although he does political films that include big name actors, directors, and producers in mainstream Philippine media, Ilagan still does not earn much and lives a rather simple life, like most cultural workers. Axel Pinpin mentioned earlier that he is a well-known and respected poet among mainstream writers, but he chooses to live and organize among the peasants. Pendong Aban, Jr., although successful in the 
Philippines during his days as a musician with Asin, lives a simpler life as a cultural worker in the U.S. What is more important to him is not if his music will provide him a comfortable livelihood, but that his music speaks to the struggles of marginalized communities. He shared with me that up to now, he does not have a steady job, he just helps take care of a rich friend's house, and helps his wife and son by driving them to and from work. Despite this simple life, he remains very popular among Filipinos in the U.S. and still gets requests to perform his music, receiving honorariums and stipends for performing.

For Elaine Villasper-Dizon, she still struggles with using her cultural work as a means of livelihood. Her main occupation is full time community organizer at the FCC, in which she receives a monthly stipend to meet her basic living needs. Though she has a substantial following in terms of her cultural work, she shared that it does not earn her much, because what is more important to her is that her cultural work is accessible and helps advance the movement. But of course, it is challenging to be able to sustain her cultural work.

I think in terms of challenges, it was trying to figure out how to make my artwork accessible so that people can have it, but at the same time make it so that it's self sustainable. I still struggle with this. When I first started painting, I was talking a lot to people who aren't organizers but are artists by profession. A lot of them were encouraging me to price it in a way that I just didn't feel right, like hundreds of dollars. It sounded right, because you should be imagining as this is a job and be paid for your hourly wage, and the cost of your materials. That all totals to a lot of money, which in the long run sounds fair for me as an artist. But it didn't feel right because I knew that the people that I would want to give this to and share with would never be able to afford that price. So I still struggle with that, because I want to make art and I want to make it accessible. I am a firm believer that once you make art, it's not yours anymore, it's everybody's, it's the people's. So I want them to have it, but at the same time, paint and materials are very expensive. So finding a way to make sure that I least make enough that I can continue to buy materials - that's hard! (Interview November 7, 2013). 
Mario Demira, also a full time organizer with Villasper-Dizon at the FCC, shared with me that he has been fortunate to be able to make his music as part of Power Struggle at little to no cost, through fellow artists generous with their recording equipment. He shared that is the easy part, especially as an independent Hiphop artist. "Hiphop is easy, you don't need anything! That's why it works for poor people. You don't really need much. In terms of equipment, you make a friend or find somebody who believes in your craft, and they can make beats for you and record in their studio." However, making an album for distribution is another story, and final mastering and mass production of CDs mostly came out of pocket for him. He shared with his album Remittances, after all the post-production costs and earnings from $\mathrm{CD}$ and digital sales, and live performances that project barely broke even. But like Villasper-Dizon, what is more important for Demira is that his music is accessible to communities so they can hear the stories of migrant workers' struggles and the values and analysis of the National Democratic Movement of the Philippines, all of which are reflected in his songs. His only challenges are the conditions of some of the events he is asked to perform at, which he acknowledges as petty but annoying.

I don't try to put to much on being a cultural worker as a means of living. But there's times when we get asked to perform somewhere, and whoever's organizing it is disorganized, and everything is not put together well. That's always kind of annoying. But I also try to analyze everyone who asked me to perform, like 'Is this going to be fruitful, or is it going to be just a mess?' So, fortunately, I've been kind of able to navigate through a lot of the requests that we get, and I haven't encountered too many disappointments (Interview November 4, 2013).

Another challenge for cultural workers in the National Democratic Movement are the internal criticisms about the cultural work being produced. Of course, cultural workers want the message to be aesthetically pleasing to be popularized while 
maintaining the principles of the movement. As with many artists, creative and ideological differences can occur among cultural workers. Axel Pinpin, one of the more confrontational cultural workers with his poetry, recalled one particular struggle he had with other cultural workers concerning one of the poems he wrote.

When I became a full time activist, I was inspired by the life of a young peasant, who became an activist at fourteen years old and wanted to join the New People's Army, but could not because of her age. When she did become a full time guerrilla and eventually martyred, I wrote a poem. The intro of my poem is, 'I left early my pickup stick, hopscotch, Chinese garter, etc.' you know, the usual kids' street games. That was the intro, very symbolic of leaving to join the revolution. It was collectively edited, but my comrades said, 'Axel, we can't use this poem.' I said in my defense, 'Why not? My only critics are the peasants and the workers.' I wanted to say to them, 'I am a writer in this group, I know what should go into this poem,' simple and clear to them. They replied, 'You know Axel, there's a campaign and propaganda by the Philippine government against young combatants. So what you're saying in your poem is for young children to be activists.' Immediately, I stepped backward and said, 'This poem is rooted in the peasants' struggle. What more do we need?' (Interview July 14, 2013).

What this particular incident of creative differences was referring to was that the National Democratic Movement of the Philippines builds a broad-based movement that works towards social change through mass, legal, and parliamentary struggles. It also recognizes the necessity of armed struggle, given the violent conditions that lead oppressed peoples to choose joining the armed struggle to defend themselves against a brutal and oppressive government. What Pinpin and his fellow writers were struggling with concerning the content of his poem was that the NPA has strict rules against people joining who are under the age of eighteen, and the other writers did not want his poem to be misinterpreted as the NPA recruiting child soldiers.

A somewhat similar internal criticism among cultural workers in the National Democratic Movement using newer forms of culture to popularize the politics of the movement. This criticism comes mainly from the more hardline activists who are very 
particular about adhering to the principles and politics of national democracy. These hardline activists are commonly referred to as "grim and determined." Marconi Calindas and his fellow cultural workers in his generation faced this criticism by the older "grim and determined" hardline activists, especially being openly gay man and using gay lingo and culture in their cultural work.

I was really baffled that I was criticized for how I dressed, because I'm trying to help the people, and just because I'm dressing a certain way doesn't mean I'm not helping them. Back in the 1970's, people dressed down. But when I was in college, we were in this new generation where we are actually active, we fight, but we wear shoes. I wasn't wearing slippers back then, I was wearing Prada shoes! So that was my challenge back then. Just because we dressed 'better,' we were told to tone it down. But we were like, 'Don't hate us because we're pretty!' I remember also we were told not to propagate the whole 'gay lingo' in the movement. We started the slogan 'Don't be saucy! Join the rally!' But we were told, 'No, you can't say that. You're alienating the workers and farmers.' But this was actually our way of making the message more pop, and therefore more appealing to the masses. The funny thing I realized was that if you talk to the leaders of the basic sectors, they're the ones who are very excited to learn about these new forms of culture! (Interview December 7, 2013).

The perspective of the National Democratic Movement of the Philippines is that the leading forces of the movement are the most oppressed sectors of society-the peasants and workers. There is a false assumption that because these are the most oppressed sectors, they do not have access to pop culture and mainstream media. That assumption might have been true in the 1970s, but in this day and age, pop culture has reached populations even with the least resources. I can speak from my experiences in my past basic mass integrations with peasant communities in the Philippines that although they have very limited access to technology, they still have radio and know who the pop singers are, even knowing more than me all the words to most American pop songs. So, to say that using newer technologies and forms of culture is alienating the peasants and 
workers is a false criticism. Calindas has heard these similar criticisms towards newer forms of cultural work.

In this age of social media, videos, and YouTube, these activists or progressive students would use these media to create a message to the community. I've heard some criticisms that 'They're so bourgeois. They're doing these MTV's now.' But they're singing these progressive songs in MTV-like videos! And they're criticizing them! Isn't that weird? I don't know why! They're stuck in the 1970s, or their old ways. It's so hard for these old generation of progressive people to accept that these are the media now that you can use! It's a generation gap. I don't think there is one correct way of doing protest art. That's something that should be very open to people's ideas, and being able to adopt with the times. And like I said earlier, if you talk to these basic sectors, they're very excited to learn these new ways (Interview December 7, 2013).

This relates back to what Axel Pinpin described as using cultural work to penetrate the mainstream and popularize the movement. Another way to describe it is commodifying pop culture, since that is what society has been bombarded with, and flipping it to advance the movement. Like any other artist, cultural workers must stay attuned to the trends that are popular with people so their art resonates with them. But the difference with cultural workers is that they do the same but use it to advance the movement. By doing so, they become the Critical Organic Catalysts, which West (1990) defines as "exemplars of what it means to be intellectual freedom fighters, that is, cultural workers who simultaneously position themselves within (or alongside) the mainstream while clearly aligned with groups who vow to keep alive potent traditions of critique and resistance."

\section{Summary}

As stated in the beginning of this section of answering the question, "How is cultural work used in the National Democratic Movement of the Philippines?", organizing communities to join this movement, those who are directly oppressed and as 
well as those who are unaware of the injustices, has bore witness to many victories as well as challenges. Creating a culture that is combats the dominant imperialist culture is not an easy task and is indeed a long-term process, as with building and sustaining any social movement. These cultural workers offered a wealth of experience that speak of the triumphs and struggles of doing cultural work, in its various forms, to popularize and expand the National Democratic Movement.

\section{Research Question 3: What are the implications of cultural work for marginalized communities in the Philippines and the United States?}

As discussed earlier, the main role of cultural workers is being organizers who are integrated in the marginalized communities they serve. By being of and with the community, and struggling alongside them, that in turn keeps the cultural work rooted and reflective of marginalized communities. When answering this research question with the cultural workers, they all agree that education is implicated in their role as organizers, reflective of the ATOR framework of cultural workers-Artist, Teacher, Organizer, Researcher. By being the ATORs in the community, cultural workers help guide them towards the political consciousness and understanding of the root causes of their struggles. Cultural work is tactic used to spark political consciousness, address social problems, and organize communities to join the movement for social change. The cultural workers in this study shared specific experiences of how they were able to accomplish these by being of and with marginalized communities.

\section{Cultural Work as Popular Education Towards Political Consciousness}

As briefly discussed in Chapter I, cultural workers are in many ways the "popular educators," or "organic intellectuals" of the communities they serve. These are vital roles 
they play in marginalized communities who have limited resources to education. In the early 2000s, Ericson Acosta was involved in the consolidation and unity of cultural organizations with a national democratic orientation, meaning they united on using cultural work to help build the movement. He was also able to bring this to the peasant communities, where spent several years as an organizer. It was a different experience from doing cultural work in the urban centers, where there are more resources, especially in education. The peasant communities have very limited resources to education, but cultural workers like Acosta used cultural work among the peasants to provide popular education, with the objectives of arousing, organizing, and mobilizing them towards political consciousness.

I was able to help in standardizing the orientation of national democratic cultural mass organizations in the youth and student sectors. I was also part of a core group that revived CAP in 2000. I also decided to be part of the antifascist, antifeudal cooperative movement in the countryside, so I spent several years in the countryside with the peasant movement, which of course has its cultural orientation and program. It's a bit different from how you do cultural work in the city, so I definitely learned a lot of things in the countryside as far a cultural work is concerned. Cultural work would directly be integrated with the anti-feudal struggle and campaigns of peasant associations, and how cultural work would be integrated in literacy and education of the peasants. I also edited publications, cultural or otherwise, especially illustrations, considering the audience were peasants. I was involved in building a cultural package in support for educational work, so using music, visuals, and even poetry (Interview July 28, 2013).

In using cultural work to create educational packages for the peasant communities, many of whom lack literacy skills, Acosta was the popular educator of the communities he integrated with. And as discussed earlier, he extended this cultural work to the other prisoners he was with, many who were illiterate, during his detainment.

In addition to being the popular educators of marginalized communities, cultural workers have the particular task of not only making the information accessible to them 
and connect to their struggles, but of sharing their artistic skills with communities who do not have resources to learn those skills. Joi Barrios-Leblanc emphasized this particular task of cultural workers.

We, the cultural workers, are the educators! Another side of it is being the front liner to the masses. For example, if you introduce a big political statement to the laborers or peasants, it's going to be difficult to explain to them. But if you make that into a production and simple way to understand, they will get it. So we think of ourselves as bridging education and facilitating that information. You use your art to articulate the issues in the people's movement. And even the whole production of art, in the current system we have, it's also about access to opportunities. Say for example, Lea Salonga would not be a famous Broadway and Western performer if she came from a very poor family where she was not taught how to act as an artist. But a lot of well known artists, whether they were privileged or not, maybe they were given access to how they can enrich their art so they can actually produce art. It's really about providing access to that opportunity to the people so that we can all become better cultural workers (Interview December 7, 2013).

With the main task of being an organizer integrated in the communities they serve, cultural workers are on the ground with the community on a daily basis. Therefore, every interaction with the people, whether they are underprivileged or privileged, presents opportunities for education about the problems of society. There are infinite opportunities to use cultural work, no matter how simple or elaborate, as popular education towards the political consciousness of everyday people. Axel Pinpin expressed the importance of cultural workers being on the ground with the community everyday, more so than producing art. Otherwise, cultural workers who produce their art in isolation from the community are not only not informed of their struggles, but are depriving themselves of opportunities to engage with them by practicing their cultural work to help spark their political awareness.

I can't be a poet just in my room, listening to Bob Dylan, The Night Watchman, or Tommy Morello, and be inspired. I need to be an activist on the ground everyday to be truly inspired and rooted. I can't imagine just doing pieces if I'm 
not conscious of the everyday people. For example, just moments ago here in the picket, the people passing by were laughing because we used a humorous phrase. The intellectual types said we must not have slept, because it was raining last night. So, everyone was asking 'How are you? Aren't you all cold? etc.' But I gave an uncommon answer. I said, 'Ang tuyo na lang, dito sa aming kampuhan, ay ang ulam. (The only thing dry here in our camp is our dried fish.)' Tuyo here meaning dried fish, but tuyo also means 'dry.' But it was symbolic that despite the rain, the peasants are staying in the picket camp, the only thing dry is our dried fish, and our resilience to challenge the regime wasn't dampened by the rain (Interview July 14, 2013).

It was through cultural work, and the National Democratic Movement overall, that allowed Elaine Villasper-Dizon to become politically conscious, a form of political education that did not come from the traditional classroom. The educational discussions and cultural work she participated in when she was first becoming active in the movement were the forms of popular education that harnessed her understanding of the reasons why Filipinos like her and her family were forced to migrate, as well as helped connect her struggles as an immigrant here in the U.S. to the struggles in the Philippines. She emphasized the importance of this connection of struggles through cultural work for Filipino immigrants like her, as well as American-born Filipinos who have somewhat of a cultural disconnect from the country their families came from.

The ND movement and its analysis gave me a deep understanding that I'm here because of what's happening in the Philippines. Even for Fil-Ams here, if you don't speak Tagalog, it's hard to connect with your family, if you were raised second or third generation and don't have a sense of your history or culture. Those things are connected to imperialism the Philippines. They're taking that away from you, like you're having identity issues because of imperialism. You're having economic problems because of imperialism. The way imperialism is now, it's global and connected to a lot of people's home countries, such as the Philippines. But we have some really concrete, messed up problems that we're facing here that's directly connected to the reasons why we left the Philippines. If you don't make the connection to that struggle, we're bound to repeat mistakes. It's like you can't talk about racism here without talking about slavery and Black exploitation. The same thing for us, we can't talk about the oppression that we face here, like immigrants getting scapegoated, without talking about colonialism and the long history of oppression that our people have been facing in the 
Philippines, and how it's connected to our experiences here (Interview November 7, 2013).

Resonating with Villasper-Dizon, Mario Demira did not become politically conscious through traditional education. He actually hated school growing up, but had a desire for learning. As he shared earlier, his political consciousness along with those who participated in the Hiphop workshop came from the educational discussions they participated in, and taking what they learned to reflect that in the cultural work they produced. These forms of cultural work provided the popular education towards political consciousness for Demira and countless others like him who felt that traditional education did not reflect their experiences. Traditional education, as discussed in Chapter II, has been used by imperialism as an oppressive institution to subjugate the hearts and minds of marginalized populations (p. 35). Cultural work as popular education has been and continues to be the counter narrative towards political consciousness and liberation, reflective of Boal's (1974) poetics of the oppressed. As discussed in Chapter II, poetics of the oppressed is "the poetics of liberation: the spectator no longer delegates the power to the characters wither to think or act in his place. The spectator frees himself; he thinks and acts for himself!" (Boal, p. 155). Demira shared this sentiment of cultural work as popular education that not only sparks political consciousness, but speaks to the struggles of the people.

I think the role of cultural work is also to propagate the stories of the people. As propaganda, it's also an educational tool, because not everyone can read, not everyone has a television, not everyone has a radio. So what kind of creative formats can we use to disseminate this kind of knowledge? That's one role, and I think that's universal for ND artists. But particularly to ND artists in the U.S., that's even harder. I think our role in the U.S. is to bring light to something that, to me - and most people in the U.S., is blocked out by the media. We're not taught about the issues in our homeland. I think that's one of our tasks, but it's also to make things educational and entertaining, and fun to captivate our 
audience. It's a challenge, because we're also combatting the bullshit culture that is propagated by corporate interests and the money machines. So it's hard to talk about equality and justice when there's a bigger media structure that talks about greed and inequality (Interview November 4, 2013).

\section{Cultural Work as an Organizing Tactic for Social Change}

Emphasizing again that the main role of cultural work is organizing, cultural work goes beyond just the artistic aesthetics of what is produced. It goes beyond just sparking the political consciousness of the audience. There is a popular quote by Cesar A. Cruz, that has been circulated widely on social media that goes, "Art should comfort the disturbed and disturb the comfortable." Applying this to cultural work, cultural work should do more than just raise awareness of social issues and injustices. It should also disturb people enough to break out of the comfort of the status quo and organize towards social justice. Reiterating Lino Brocka's poem Artist as Citizen and Zinn’s (2003) perspective of artists and transcendent, it is the patriotic duty of cultural workers as citizens of society to transcend the establishment and organize communities into social action, combatting what they view as bourgeois imperialist culture and creating a culture reflective of the people. Ericson Acosta emphasized this duty of cultural work as an organizing tactic.

Cultural work among the basic masses, the peasants and workers, is a very significant part of organizing. Of course the basic sectors have access to culture. They have access television, to the bourgeois and feudal culture. They have access to bourgeois imperialist music. So there is need to divert that culture the state is offering to the masses in general. It's coming from the analysis that culture itself, as part the superstructure, is dominated by the ruling class and used in order to justify the ruling system. One way of fighting the ruling system is to make culture itself as a field of battle. As far as the national democratic revolution is concerned, you have the primary role of armed struggle to take state power. But definitely you need to mobilize the masses towards this revolutionary project. One way is arouse them to realize the reality of their oppression and exploitation, that the dominant culture is part of the system that oppresses and exploits. So you use culture, art, literature, etc., in reaching out to the masses. Learning about 
revolution, or its theory, or even learning about semi-feudalism and semicolonialism is not an easy task. But when you have songs, theater, poetry, etc., especially one that is effective, has a good hook, it's very important in education work. Art and literature would make the education more alive. Art and literature can be considered as a beautiful fan that fans the flame. So, the task of cultural work is to make regular, timely critiques of what the dominate culture is offering (Interview July 28, 2013).

As citizens responsible to the society they are part of, cultural workers use their artistic skills to spark political consciousness and organize communities into social action against the systems of oppression. The particular task of cultural workers is making the message of social justice accessible to marginalized communities, then guiding them to use their political consciousness towards social action. Just like any artist and any art form, growth is the result of practice. Cultural workers, and the cultural work they produce, must be socially practiced in order for marginalized communities to be organized and for the growth of the movement. Villasper-Dizon emphasized this responsibility of cultural workers towards organizing.

I think a lot of the roles that we play as cultural workers is the same as any other organizer. Our role is to agitate, mobilize, and organize the people most oppressed. The difference for cultural workers is that we have a particular talents that we can use in organizing. It's the merging of those two things - taking your skills in the artwork that you can produce, and using that in a responsible way in responding to the needs of the people we're organizing, the people we're reflecting, the people we're fighting for. For personally, it's to make art not for myself, but for the people - trying make art that's reflective of the people I serve, the people that I organize with, and in the end try to give it back to them. That's what I'm trying to do, make artwork accessible, reflective, but also not just see myself as an artist, but really engage in the process of organizing in social justice (Interview November 7, 2013).

\section{Summary}

The implications of cultural work for marginalized communities in the Philippines and the United States are that cultural work is a form of popular education towards political consciousness of communities as well as an organizing tactic for social change. 
Cultural workers are the "popular educators," or "organic intellectuals" of the communities they work with, providing the education that they do not have the resources to access. It is also the patriotic duty of cultural workers as citizens of society to transcend the establishment and organize marginalized communities into social action, combatting what they view as bourgeois imperialist culture and creating a culture reflective of the people. According to cultural workers, cultural work should also disturb people enough to break out of the comfort of the status quo and organize towards social justice. Through cultural work in the National Democratic Movement in the Philippines, marginalized communities in the Philippines and the U.S. are awakened to political consciousness, are organized to address social problems, and mobilized to expand the movement for social change. 


\section{CHAPTER V}

\section{DISCUSSION, CONCLUSIONS, RECOMMENDATIONS, AND REFLECTIONS}

As stated in the beginning of this study, the purpose of this study was twofold: to examine the extent to which cultural work brings political consciousness to marginalized populations in the Philippines and the U.S. who do not have access to education, and to examine the impact of cultural work locally and transnationally as a tool for social change and addressing issues that impact marginalized populations, particularly in the National Democratic Movement of the Philippines.

\section{Discussion}

\section{According to cultural workers, what is cultural work and how does it look in a transnational context?}

In my conversations with the cultural workers, they had many common definitions of what cultural work and cultural workers are, as well as their roles in the National Democratic Movement in the Philippines beyond the borders of the Philippines. Cultural work and cultural workers are intentional and decisive in producing art as a tactic to transcend and transform the world we live in. Resonating with Lino Brocka's poem Artist as Citizen and Zinn's (2003) perspective of artists and transcendent, it is the patriotic duty of cultural workers as citizens of society to transcend the oppressive establishment and organize communities into social action, combatting what they view as bourgeois imperialist culture and creating a culture reflective of the people. As Ilagan shared, cultural workers see cultural work in terms of culture as a whole, reflecting all aspects of the culture we are living in — the struggles of those who are oppressed, identifying the oppressor and its forms of dominant culture, and formulating solutions to 
address social problems. For cultural workers in the National Democratic Movement of the Philippines, cultural work is used to reflect and give voice to the most oppressed sectors of society, to identify U.S. imperialism as the major adversary to creating a national democratic culture, and to most importantly organize alongside marginalize communities towards finding solutions to end oppression.

As with the National Democratic Movement of the Philippines, cultural work also transcends the national borders, as Filipino cultural workers in the diaspora are not just reflecting the oppressive neocolonial society in the Philippines, but connecting that struggle to other struggles wherever they are in the world. This is one of the reasons why the National Democratic Movement of the Philippines and its cultural work is considered what Rodriguez (2010) calls "counter hegemonic (trans)nationalism."

A common thread among the cultural workers in this study is that cultural work is defined as more than just the art created. It is a tactic in organizing populations that have been marginalized by the effects of imperialism, exposing and opposing the injustices of imperialism, and decisive in creating a culture of critique and resistance. For all cultural workers, the main role is that of organizer, and their art comes secondary, informed by struggles of the communities they are integrated. They are more than just artists, they are ATORs - Artist, Teacher, Organizer, Researcher. By being the ATORs who are of and with the community, they also become the critical organic catalysts, which Cornel West defines as "exemplars of what it means to be intellectual freedom fighters, that is, cultural workers who simultaneously position themselves within (or alongside) the mainstream while clearly aligned with groups who vow to keep alive potent traditions of critique and resistance" (p. 9). Another common thread is that cultural work in the movement extends 
beyond the borders of the Philippines, as Filipinos are a diasporic people forced out of the Philippines because of social problems plaguing the country. The National Democratic Movement of the Philippines is one that engages in "counter-hegemonic (trans)nationalism" (Rodriguez, p. 152). As the participants in this study shared, cultural work is to create a culture that is reflective of the people, a culture that is counter to what they describe as the hegemonic bourgeois imperialist culture. For cultural workers in the U.S., their have the particular task of doing cultural work to advance the movement in U.S., which they regard as the center of imperialist culture —or as they have come to call "the belly of the beast."

\section{How is cultural work used in the National Democratic Movement of the Philippines?}

When we discussed how cultural work is used in the movement, the cultural workers shared mainly their own personal experiences of being cultural workers, both the highlights and challenges. While organizing marginalized communities to join the movement, both those who are directly oppressed and as well as those who are unaware of the injustices, there have been many victories as well as challenges. Creating a culture that is a counter narrative to the dominant narrative of imperialist culture is not an easy task and is indeed a long-term process. By using cultural work in their various ways of integrating and organizing with marginalized communities, the participants in this research were able to create counter narratives to the various dominant narratives that have rendered their histories irrelevant. As with Ilagan's experience of direct integration in the community contributing to the expertise of cultural workers like him who used theater, and Demira's music being informed by his migration story and active participation in the step-by-step organizing an building power in communities, creating 
counter narratives to the dominant oppressive narrative came about through social practice, similar to Boal's poetics of the oppressed. By being directly integrated in the everyday lives of the oppressed, cultural workers along with communities they serve create a culture of critique and resistance, which according to them is the culture and society they want to see for themselves. Cultural workers and the marginalized communities they are integrated in provide the narrative themselves, countering the dominant narratives of imperialism that have spoken for them for so long. In this process, many of the cultural workers have witnessed or experienced human rights violations, such as forced displacement, abduction, detainment, torture, and extrajudicial killings. They have survived to tell their stories and the stories of other survivors through their various forms of cultural work, as well as to advance the National Democratic Movement-all victories in and of themselves.

As stated in the beginning of this section of answering the question, "How is cultural work used in the National Democratic Movement of the Philippines?" organizing marginalized communities to join this movement, those who are directly oppressed and as well as those who are unaware of the injustices, has bore witness to many victories as well as challenges. Creating a culture that is combats the dominant imperialist culture is not an easy task and is indeed a long-term process, as with building and sustaining any social movement. These cultural workers offered a wealth of experience that speak of the triumphs and struggles of doing cultural work, in its various forms, to popularize and expand the National Democratic Movement. Like Della Porta \& Daini (2006) definition of a social movement, cultural workers shared similar sentiments that the National Democratic Movement is a "distinct social processes consisting of the mechanisms 
through which actors are collectively engaged in conflictual relations with clearly identified opponents, are linked by dense informal networks, share a distinct collective identity" (Della Porta \& Diani, p. 20). As with the experiences of Ilagan during Martial Law, Acosta during the resurgence of the movement in the 1990s, and Villasper-Dizon in helping build the movement in the U.S., struggle only served to fuel cultural work in expanding the National Democratic Movement. In their specific experiences, the cultural workers in this study used their respective forms of cultural work to integrate with communities and garner support and membership from a broad spectrum of sectors. Through cultural work and the ubiquitous organizing that goes along with it, this transnational movement shares a collective identity as a people fighting against imperialism and the various systems of oppression it manifests, ultimately fighting for national democracy in the Philippines.

\section{What are the implications of cultural work for marginalized communities?}

As discussed earlier, the main role of cultural workers is being organizers who are integrated in the marginalized communities they serve. By positioning themselves and identifying with marginalized communities and struggling alongside them, they keep cultural work rooted and reflective of their struggles. When exploring this research question with the cultural workers, they all agree that education is implicated in their role as organizers, reflective of the ATOR framework of cultural workers-Artist, Teacher, Organizer, Researcher. By being the ATORs in the community, cultural workers help guide marginalized communities towards the political consciousness and understanding of the root causes of their struggles. The ATOR framework is reflective of Boal's (1974) poetics of the oppressed, in which cultural workers position themselves alongside 
marginalized communities guide them into becoming organizers themselves - from being merely spectators into "spec-actors" (p. 155). Cultural work is tactic used to spark the political consciousness of marginalized communities, address social problems, and organize to join the movement for social change. The cultural workers in this study shared specific experiences of how they were able to spark political consciousness and organize marginalized communities. Demira was able to practice this in helping organize Filipino caregivers through the CARE Project, which was intentional in utilizing poetics of the oppressed. Through this form of cultural work, the Filipino caregivers were able to articulate the struggles they were facing, such as wage theft, unsafe working conditions, and remittances as their only connection to back in the Philippines. This in turn led them to organize themselves into forming Migrante-SF, an overseas chapter of Migrante International, which advocates for the rights and welfare of overseas Filipino workers. This was similar to Ilagan's and Barrios-Leblanc's experience of building a national federation of theater and cultural groups to compliment and help build the National Democratic Movement. Also similar is Acosta's experiences of building the movement through the formation of Alay Sining, which at the time became a model for succeeding National Democratic cultural organizations that formed, as well as creating literacy educational materials with the peasant communities he integrated with. These are all examples of how through cultural work, marginalized communities can organize themselves and help build a movement.

The implications of cultural work for marginalized communities in the Philippines and the United States are that cultural work is a form of popular education towards the political consciousness of marginalized communities as well as an organizing tactic for 
social change. Like Acosta's experience, cultural workers are the "popular educators," or "organic intellectuals" of the communities they integrate with, providing the education that they do not have the resources to access. It is also the patriotic duty of cultural workers as citizens of society to transcend the establishment and organize communities into social action, combatting what they see as bourgeois imperialist culture and creating a culture reflective of the people. They also believe cultural work should disturb people enough to break out of the comfort of the status quo and organize towards social justice. Through cultural work in the National Democratic Movement in the Philippines, marginalized communities in the Philippines and the U.S. become aware of the social problems they face, are organized to address them, and mobilized to expand the movement for social change. As with Axel Pinpin sharing his experience of Hiphop, a music and arts culture that originated in the U.S. that has its roots in struggle and resistance, it was one form shared with cultural workers in the Philippines by cultural workers based in the U.S. who are also part of the National Democratic Movement, to popularize and advance the movement in marginalized communities not just in the Philippines, but beyond its borders. In the same vein with Demira and his cultural work through the form of Hiphop music, cultural work builds the connectedness of Filipinos in the diaspora back to the Philippines. It is through cultural work in the National Democratic Movement that this bridge back to the Philippines builds nationalism beyond just the nation state. In this sense, it also complicates notions of "transnational" as simply a transfer of funds or of overseas workers, but more so a transnational social movement built on "counter hegemonic (trans)nationalism" (Rodriguez, 2010, p. 152) 


\section{Conclusions}

As stated throughout this study, a cultural worker is defined an artist who creates art with a purpose that is socially responsible and organizes alongside marginalized communities. The first part of the title of this study, Artist as Citizen, inspired by Lino Brocka's poem, exemplify what it means to be a cultural worker: "The artist is a committed person, that he will always take the side of any human being who is violated, abused, oppressed, dehumanized whatever his instrument — the pen, the brush, or the camera." Cultural workers have the vital role in making the message of change that is accessible to marginalized communities, through whatever art form. As shared by the participants in this study, people may not connect with a speech or a theory-dense book on social change, but they will instantly connect to creative art piece concerning social change. Cultural work challenges mainstream cultural notions of what art and culture are and their purposes in society. Cultural workers are intentional in creating culture as an act of resistance imperialism, as of the stories they tell though their creative work are not revealed much in literature, society, and mainstream media. Cultural workers also seek to debunk the myth of artists working in isolation from the community. Cultural workers are not just artists, but as shared by the cultural workers in this study, are most importantly community organizers working closely with marginalized communities, and in many ways are "popular educators" and "organic intellectuals."

The theoretical framework of this research was grounded on three primary overarching theories. The first theory this study was grounded on was Augusto Boal's (1974) Theater of the Oppressed, which uses art and theater produced by cultural workers alongside marginalized communities as tools of activism and organizing. Cultural 
workers in the National Democratic Movement of the Philippines have and continue to accomplish this in the creative pieces they create through the many mediums of art. Much of what is has happened in their lives informs the art they produce. They choose to tell their stories using art because it is a language that is very accessible. All the participants in his study shared the different ways they used cultural work to engage with the community and organize them, such as the literacy educational materials Acosta helped create for the peasant communities he integrated with, the art workshops Calindas help conduct for poor communities who lack access to art materials, and the poetry of Pinpin being inspired by the narratives of the peasants.

The second theory this study was grounded on was Cornel West's (1990) New Politics of Difference, whose definition of critical organic catalyst is closely parallel with the definition of cultural worker. West defines this as "exemplars of what it means to be intellectual freedom fighters, that is, cultural workers who simultaneously position themselves within (or alongside) the mainstream while clearly aligned with groups who vow to keep alive potent traditions of critique and resistance” (p. 9). Cultural workers produce their cultural work not necessarily to be included in or outdoing mainstream forces. They produce their cultural work simply to give voice to themselves, usually aligned with the marginalized. Cultural work is to engage in social liberation of those within the margins of society. As Axel Pinpin shared, one of the tasks of cultural workers is to popularize the National Democratic Movement, taking what is popular in mainstream culture and flipping it to convey the analysis of the movement. Marconi Calindas and Boni Ilagan also shared this task of popularizing the movement by adapting and using newer forms of technology, especially in video production and social media. 
Elaine Villasper-Dizon and Mario Demira also accomplished this task, with VillasperDizon using kid-friendly visual art and Demira using Hiphop music. All these respective forms of cultural work come from the narratives of marginalized communities, particularly the peasants, workers, and migrants.

The third theory this study was grounded on were the social movement theories of Donatella Della Porta \& Mario Diani (2006), which define social movements as distinct social processes of collective action. These processes, rather than being based on isolated actions such as mobilizations, are long-term processes. The National Democratic Movement of the Philippines defines itself as continuing the unfinished Philippine Revolution of 1896 , for as long as there are institutional systems that deny people their rights, there will be social movements of resistance. The National Democratic Movement of the Philippines attributes their longevity to their belief that the current oppressive system must and will fall, if not for them, then for future generations to continue the struggle. The participants in this study represent this longstanding struggle of the National Democratic Movement, some having started as early as the late 1960s and early 1970s with the First Quarter Storm and throughout Martial Law, and some starting during the 1990s and 2000s. A testament to this long-term collective process as a social movement is that all the participants in this study are still active in the National Democratic Movement of the Philippines to this very day.

The participants in this study all confirmed the assumptions offered by these three theories through the experiences they shared as cultural workers in the movement. Their organizing through cultural work is in essence the social practice of Theater of the Oppressed. Their role as critical organic catalyst is exemplified their practice of being 
the ATORs with the communities they align themselves with. Pinpin pushed this theory further by not identifying as a cultural worker, but first and foremost as an organizer who is one the ground everyday with communities most marginalized. He describes his poetry as being incidental, or secondary to his main task as organizer. Lastly, the cultural workers in this study described and identified with the National Democratic Movement of the Philippines closely as a social movement with a distinct social process of transnational collective action.

\section{Recommendations for Further Research}

While conducting this narrative research on transnational cultural work in the National Democratic Movement of the Philippines, the participants spoke from firsthand experience of cultural work both in the Philippines and the U.S. that addressed the main research questions that led to this study. They were able to speak on the role of cultural work in this movement locally and transnationally, how it is used as an organizing tactic, and its implications for marginalized communities.

The perspectives on cultural work in this research came from the cultural workers themselves, sharing how they use cultural work in the movement and how they view its impact on marginalized communities. However, since what stressed by the cultural workers in this study is the importance of them being of and with the communities they work with, this importance presents another opportunity for further research to expand on the impact of cultural work in marginalized communities: to get the perspectives of not the cultural workers, but of members of the communities they work with as well as audiences of cultural work. This was one realization I had towards the end of this study. In all my years of being an organizer in the National Democratic Movement of the 
Philippines, I have witnessed its immense growth. Membership has expanded with community organizations, regional formations, as well as international chapters. The political analysis of its members continues to sharpen and grow. Cultural events to raise awareness of social issues and build membership and community are ubiquitous with the movement, with such events happening on a monthly and sometimes weekly basis. While the movement has produced many cultural workers, more importantly it has produced much more community organizers, most of whom do not identify as cultural workers. Some are like Axel Pinpin, organizers who have creative outlets and use their creative talents for the movement, but see their art as secondary to their primary role of organizer. And some identify as organizers not only because of their ability to carry out their daily tasks and organize the community, but simply because they feel they do not have a creative talent like playing a musical instrument, painting a picture, or theatre.

While not displaying any artistic talents, organizers who do not identify as cultural workers are very talented and skilled in building with communities, organizing events, and planning out programs of action for their organizations. More particularly, they are also very talented and skilled in planning and implementing events and mobilizations that feature cultural work. Many events, such as the annual SONA ng Bayan, fundraisers for Philippine typhoon disaster relief, and film tours like Dukot and Migrante that highlight the struggle of the Filipino people, were organized and led by activists who do not identify as cultural workers but view cultural work as a powerful way of propping and advancing the movement.

It would be interesting and important to get perspectives on cultural work from organizers who do not identify as such, but are very talented and skilled in other areas of 
work in the movement. One example is a strong leader and skilled community organizer in this movement. She has taken lead on many cultural events, but to put it bluntly, cannot dance nor sing in tune, despite her best efforts. Many in the movement often joke about her, endearingly, that her immense talents in community organizing and mobilizing more than make up for her lack of artistic talents. She has a collection of political films on DVD along with socially conscious artwork and music, yet she does not possess any visible artistic talents herself. But all jokes aside, she often credits cultural work in the National Democratic Movement as helping her sharpen her political analysis and strengthening her resolve for serving the community. Many mobilizations and cultural events would not have run smoothly and effectively if not for strong leaders and skilled organizers like her.

Other perspectives on cultural work to gather is from audiences who attend cultural events and consume the products of cultural workers, but are simply that - an audience. They attend these cultural events and consume the art produced, but do not participate in the community organizing that the cultural work is propping. One example is I remember being at Hiphop show that Nomi Demira performed at as part of his rap group Power Struggle, and he performed all of his songs that talked about workers' and migrants' struggles. After the show, a young man enthusiastically approached Nomi and asked him to autograph his Power Struggle CD and T-shirt, while saying how much he loves his music and always goes to his shows. I would be interested to know what is going on in the mind of this young man, an audience of cultural work who may not—or may be, an organizer. One of Power Struggle's songs explicitly says to not just listen to the music, but go out to the community and organize to build political power. I would 
want to ask that particular young man what he thinks when he listens to Power Struggle's music, especially the songs about the National Democratic Movement of the Philippines.

That particular moment is one example of audiences of cultural work. Going back to Axel Pinpin sharing about his experience being not just an organizer but part of an elite writers' group in the Philippines, he shared that he is only writer in the group who is also an organizer. The other writers are writers by profession and do not do community organizing, yet they hold Axel in a high regard and helped advocate for his release during his political imprisonment. I would like to know what they think of his writing and organizing, as well as their views of the National Democratic Movement of the Philippines.

These two perspectives are important to include for further research on cultural work in the National Democratic Movement of the Philippines - organizers who do not identify as cultural workers, and audiences of cultural work. As discussed, cultural workers use cultural work to expand and broaden the reach of the movement, so it would be important to also include the perspectives of audiences of cultural work who do not participate in community organizing, who fall under this broad reach.

\section{Reflections of the Researcher}

There are still so many stories to tell, and so many valuable lessons learned, in all my experiences with my fellow cultural workers over the years and connecting them to my research, that no amount of research can fully capture the comprehensive experience of transnational cultural work in the National Democratic Movement of the Philippines. That comprehensive experience can only be captured by being immersed with marginalized communities. But if there is one thing I can say about my journey as a 
scholar-activist and cultural worker in this movement, I can sum it up in one word: Love. In the midst of all the hard work, all the anger and rage against the imperialist machine that are channeled creatively through our cultural work, and all the joy and laughter, I can not help but fall in love, deeply. I have fallen in love with the movement for national democracy that crosses international borders. I have fallen in love with all the work that drive this movement. Most especially, I fell in love with the people, both my fellow activists and the people we serve. It was their passion, creativity, humility, and love for the people that melted my heart over the years.

I can remember a stage in my activism that was guided by nothing but rage and anger, the stage of being "grim \& determined," as previously discussed. It was during this stage when despite my good intentions, I instead had made enemies and my approach had burned bridges rather than being uplifting and unifying. I then realized a very humbling life lesson, as the famous revolutionary Che Guevarra said, "At the risk of sounding foolish, a true revolutionary is guided by feelings of love.” My grim and determined stage was almost a decade ago, and though I etched that lesson into my head, it was doing cultural work and being close to the people, in every way and step imaginable, that etched that lesson into my heart. And that I why I say I fell in love.

All these experiences have made me the cultural worker I am today, fully embracing the role of Artist, Teacher, Organizer, and Researcher (ATOR). As an artist, I simply create, and encourage the creativity and harnessing of my fellow artists. As an teacher, I am a popular educator and organic intellectual who teaches the history and culture of our people in order to understand the root causes of our current experiences and issues, and in turn encourage the people to also become the popular educators and 
organic intellectuals of their communities. As an organizer, I work and participate in campaigns that address social injustices faced not just by Filipinos, but all people, personally, locally, and globally. And as a researcher, I work alongside and integrate with marginalized communities facing injustices, who are the real experts of injustices because they are experiencing them firsthand. These are the things that encompass who I am, which inspired me to create my own acronym of what it means for me to be a cultural worker, which are The 3 C's-Conscious, Committed, and Creative. Cultural workers are conscious of the experiences faced by all people, all cultures, and all communities. Cultural workers are committed to their respective art forms and to the audiences and communities they serve. And cultural workers are creative, finding innovative ways to convey the message within their creative pieces that reflect their consciousness and commitment. These are also why I believe cultural workers are the popular educators of the people. A cultural worker does not simply disseminate information, but finds creative ways to make the content accessible and help the people harness their creative talents to reflect their experiences and what they learn, in whatever the space is - the street corner, the community center, the classroom, or the stage. This is true throughout the history of virtually all cultures. The sage, the shaman, the poet, the dancer, the chanter, the musician - all were popular educators and organic intellectuals, using their respective art forms. 


\section{REFERENCES}

2006 state of emergency in the Philippines. Retrieved from http://en.wikipedia.org/wiki/2006_state_of_emergency_in_the_Philippines

Araullo, C. P. (2009). Carnage waiting to happen. In Streetwise / Business World, November 28, 2009. Retrieved from http://bulatlat.com/main/2009/11/28/carnagewaiting-to-happen/

Banks, M. (2007). The politics of cultural work. Basingstoke, UK: Palgrave.

Basso, L. (Ed.). (2007). Guilty: The Verdict of the Permanent Peoples' Tribunal Second Session on the Philippines. Manila, Philippines: IBON Foundation.

Boal, A. (1974). Theater of the oppressed. New York, NY: Theater Communications Group.

BAYAN USA: Bagong alyansang makabayan (new patriotic alliance) $>>$ history. Retrieved from http://bayanusa.org/?page_id=27

Bhabha, Homi K. (1990). Interrogating identity : the postcolonial prerogative. Anatomy of racism. Ed. David Theo Goldberg. Minneapolis: University of Minnesota Press.

Cammarota, J \& Fine, M. (2008). Revolutionizing education: youth participatory action research in motion. New York: Rutledge.

Choudry, A. (2007). Transnational activist coalition politics and the de/colonization of pedagogies of mobilization: learning from anti-neoliberal indigenous movement articulations. In International education, vol. 37, no. 1. pp. 97-112. University of Tennessee.

Choudry, A. (2009). Learning in social action: knowledge produced in social movements. In McGill journal of education. vol. 44, no. 1. pp. 5-10.

Choy, C. C. (2003). Empire of care: nursing and migration in filipino american history. Durham: Duke University Press.

Chua, P. (2009). Ating kalaygayan: the social and economic profile of U.S. filipinos. Woodside, NY: National Bulosan Center.

Concerned artists of the philippines. Retrieved from http://caphil.blogspot.com/2007/11/concerned-artists-of-philippines.html

Constantino, R. (1982). The miseducation of the filipino. Quezon City, Philippines: Foundation for Nationalist Studies. 
Constantino, R. (1975). The philippines: a past revisited. Quezon City, Philippines: Renato Constantino.

Convention against torture. Retrieved from http://www1.umn.edu/humanrts/instree/h2catoc.htm

Could cia interrogation have damaged memories? (2009, September 22). Retrieved from http://www.sfgate.com/cgi-bin/article.cgi?f=/c/a/2009/09/22/MNB219QCS9.DTL

Creswell, J. W. (2012). Educational research: planning, conducting, and evaluating quantitative and qualitative research. 4th ed. Saddle River, NJ: Merrill/Prentice Hall.

Della Porta, D., \& Diani, M. (2006). Social movements: an introduction, second edition. Oxford: Blackwell Publishing.

Della Porta, D., Andretta, M., Mosca, L., \& Reiter, H. (2006). Globalization from below: transnational activists and protest networks. University of Minnesota Press.

Della Porta, D. \& Tarrow, S. G. (2005). Transnational protest \& global activism. Lanham, MD: Rowman \& Littlefield Publishers.

Digo, R. F. Lino brocka. Retrieved from http://www.oocities.com/sinupan/brocka.htm

Emerson, R. M., Fretz, R. I., and Shaw, L. L. (1995). Writing ethnographic field notes. Chicago: University of Chicago Press.

Ferdinand marcos. Retrieved from http://en.wikipedia.org/wiki/Ferdinand_Marcos

Fernandez, D. G. (1987). Philippine theatre after martial law. In Asian theatre journal, vol. 4, no. 1. pp 108-114. University of Hawai'i Press.

Gonzalves, T. S. (2009). The day the dancers stayed: performing in the Filipino/American diaspora. Philadelphia, PA: Temple University Press.

International convention of civil and colitical rights. Retrieved from http://www1.umn.edu/humanrts/instree/b3ccpr.htm

Justice for melissa roxas. Retrieved from http://justiceformelissa.org/2009/08/poem-bymelissa-roxas/

Karapatan Alliance for the Advancement of People's Rights. 2010 year-end report on the human rights situation in the philippines. (2010 December). 
Karapatan Alliance for the Advancement of People's Rights. Sugar coated crisis and terror: karapatan 2011 year-end report on the human rights situation in the philippines. (2011 December).

Lather, P. (1986). Research as praxis. In Harvard educational review, volume 56, number 3, p. 257-277. Harvard: Harvard College.

Mayotte, C. (Ed.), (2013). The power of the story: the voice of witness teacher's guide to oral history. San Francisco: McSweeney's.

Mercado, M.A. (Ed.). (1986). People power: an eyewitness story. Manila, Philippines: The James B. Reuter, S.J., Foundation.

Orientation with Migrante International, July 2010.

Posadas, B. B. (1999). The Filipino americans. Westport, CT: Greenwood Press.

President cory aquino's historic speech before the u.s. congress (2 of 3). (2008). [Web]. Retrieved from http://www.youtube.com/watch?v=G4gWe6KkFX4

Proclamation 1081 and martial law. Retrieved from http://countrystudies.us/philippines/28.htm

Reissman, C. K., (2008). Narrative methods for the human sciences. Thousand Oaks, CA: Sage Publications.

Report of the special rapporteur on extrajudicial,summary or arbitrary executions, philip alston. Retrieved from http://www.karapatan.org/AlstonReport

Rodriguez, R. M. (2010). Migrants for export: how the philippine state brokers labor to the world. University of Minnesota Press.

San Juan, Jr., E. (1998). From exile to diaspora: versions of the filipino american experience in the united states. Quezon City, Philippines: Ugnayan Para sa Makabayang Kamulatan (Linking for Patriotic Awareness), Inc.

San Juan, Jr. E. The national democratic struggle in the philippines. [PDF document]. Retrieved from http://web.uvic.ca/ anp/Public/posish_pap/San_Juan.pdf

Sison, J. M. (1966). The need for a cultural revolution. Speech delivered at the University of the Philippines, Baguio College, Baguio City.

Sison, J. M. (1995). The struggle for national democracy. Lagda Publishing.

Smith, L. T., (1999). Decolonizing methodologies: research and indigenous peoples. London \& New York: Zed Books, Ltd. 
Strobel, Leny M. (2001). Coming full circle: the process of decolonization among post1965 filipino americans. Giraffe Books.

Tadiar, N. X. (2008). Cultural revolution internationale? neferti x. tadiar and jonathan beller in conversation. In Cntrl+p journal of contemporary art, no. 11. London: University of the Arts.

Tadier, N. X. M. (2009). Things fall away: philippine historical experience and the makings of globalization. Durham: Duke University Press.

Tarrow, S. (2005). The new transnational activism. Cambridge University Press.

Tintiangco-Cubales, A. (2009). Open the light: performing filipina/o american literature. In At 40: asian american studies@ @an francisco state. San Francisco: Asian American Studies Department, San Francisco State University.

Tintiangco-Cubales, A., et al. (2007). Pin@y educational partnerships: a Filipino american studies sourcebook series, volume I. Phoenix Publishing House International.

Universal declaration of human rights. Retrieved from http://www.un.org/en/documents/udhr/

Van Erven, E. (1987). Philippine political theatre and the fall of ferdinand marcos. In The drama review: tdr, vol. 31, no. 2, pp 57-78. The MIT Press.

What martial law was like. (2000 March 27). Retrieved from http://www.hotmanila.ph/file1081/1081.htm

West, Cornel. (1990). The new cultural politics of difference. [PDF document]. Retrieved from http://bobbybelote.com/!!teaching/Readings/WestDiffrnce.pdf

Zinn, H. (2003). Artists in times of war in Artists. In Times of War and Other Essays. New York: Seven Stories Press. p. 7-37. 


\section{APPENDIX - Instrumentation (Research Questions)}

The following questions were asked to the participants of this research in order to give as much scope of their personal history, their family's history, and their lives as cultural workers. They are organized based on the three main research questions. Although the questions were organized as shown below, the interviews did not strictly follow a set sequence of answering the questions, as our conversations were loose enough to have answered a few questions ahead of sequence or a few questions behind.

1. According to cultural workers, what is cultural work and how does it look in a transnational context?

a. To set the context of the social conditions that led them to this point as cultural workers:

i. Where do you currently live? How did you come to live there?

ii. What do you do for a living?

iii. What did your parents do for a living while you were growing up? iv. What is your level of education?

v. What is your parents/family's level of education?

vi. Where are you from in the Philippines (if they are from the Philippines)?

vii. Where is your family from in the Philippines?

viii. Why did they migrate from the Philippines?

ix. What conditions in the Philippines pushed them to migrate?

x. What conditions in the U.S. pull them to migrate?

xi. Do you identify yourself as Filipino or Filipino American? Why? 
b. How and why did artists who are activists come to be referred to as cultural workers?

c. How and why did art and literature come to be referred to as cultural work?

d. What do you think is the role of cultural work transnationally?

e. How does local cultural work connect to transnational cultural work?

2. How is cultural work used in the National Democratic Movement of the Philippines?

a. What is the history of cultural work in the ND movement?

b. How did you become a cultural worker in the ND movement?

c. What organizations have you been part of? How did you start working with them?

d. What are some of the high points and low points of your life thus far as a cultural worker?

e. What are you some of the things you are currently working on? (projects, campaigns, events, etc.)

f. What is the main medium of art in your cultural work? Why?

g. What are some of the challenges cultural workers face as artists and activists in the ND movement?

3. What are the implications of cultural work for marginalized communities?

a. What kinds of communities do you work with? (i.e. workers, youth, students, women, LGBTQ, professionals, etc.) 
b. How has your experience through cultural work been in working with the communities you serve?

c. What do you think is the role of cultural work in the ND movement for marginalized communities? 